\title{
FISHES AND FISHERIES
}

OF THE

\section{IRISH SEA}

And Espectally of the Lancashire and Western Sea-Fisheries District.

By

W. A. HERDMAN, D.Sc., F.R.S.,

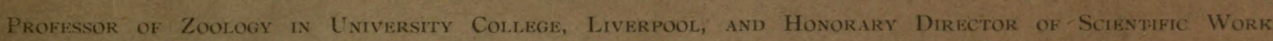
to the Lancashire Sea-Fishertes Committee:

AND

ROBERT A. DAWSON,

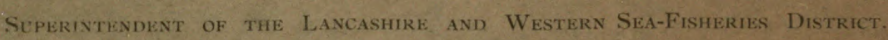

WITH ILLUSTRATIONS.

Price Five Shillings net.

LONDON: GEORGE PHILIP \& SON, LTD., 32 FLEET STREET, E.C. LIVERPOOL: 45 TO 5 I SOUTH CASTLE STREET.

AND ALL BOOKSELLERS. 


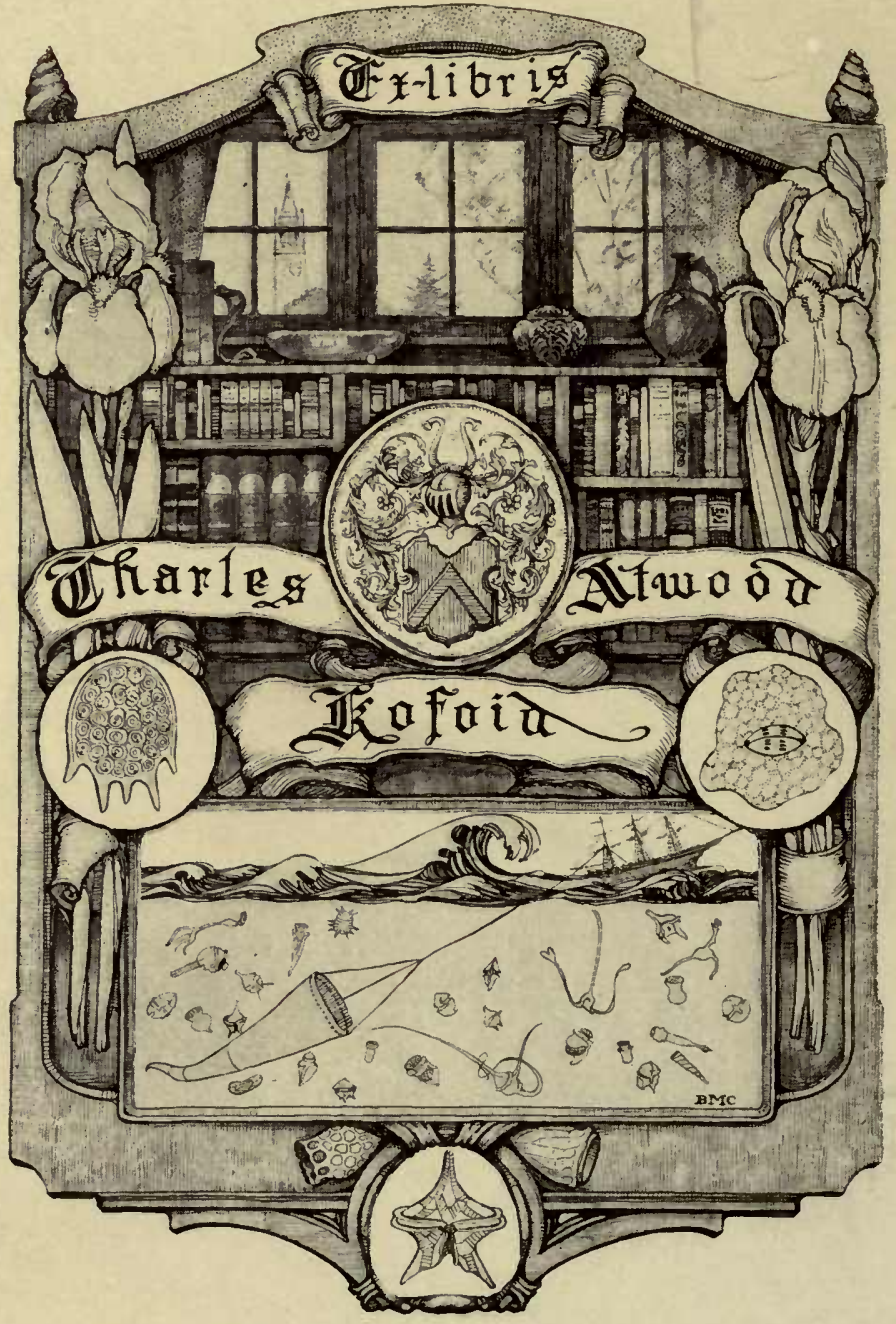




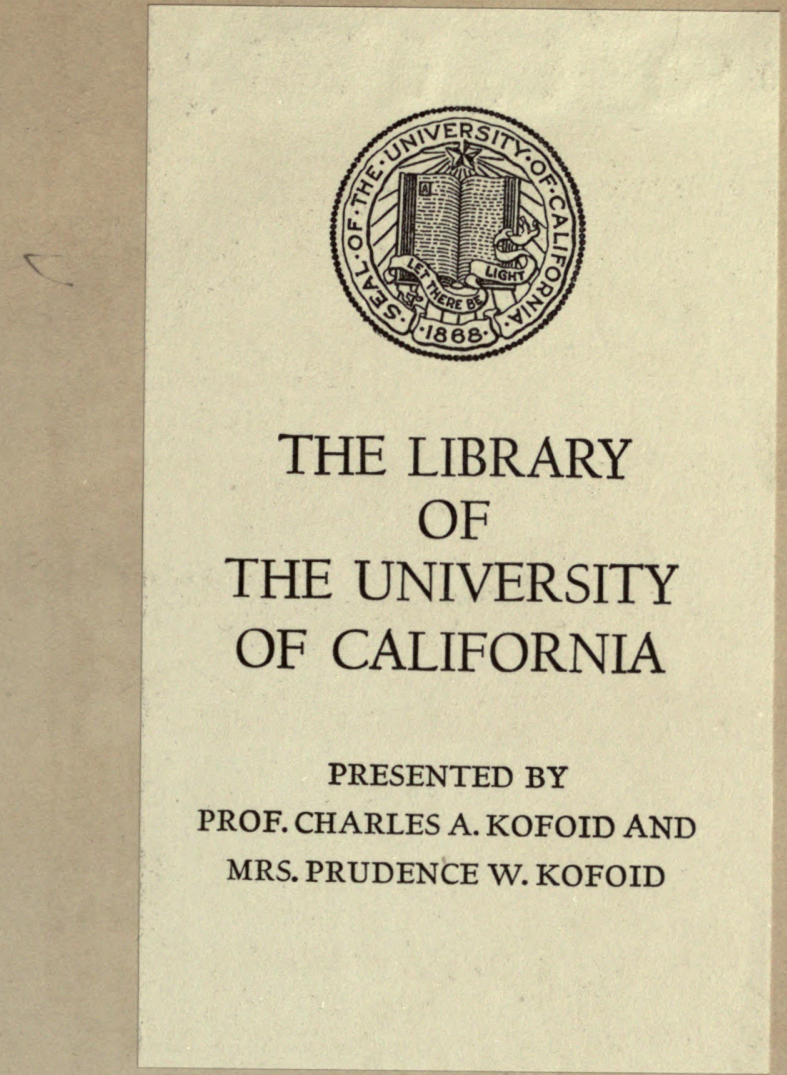


टनाभ भमटान कर टनНटान

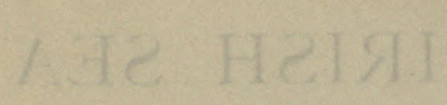




\section{LANCASHIRE SEA-FISHERIES MEMOIR-NO. II.}

\section{FISHES AND FISHERIES \\ OF THE}

\section{IRISH SEA}

And Especially of the Lancashire and Western Sea-Fisheries District.

By

W. A. HERDMAN, D.Sc., F.R.S.,

Professor of Zoology in University College, Liverpool, and Honorary Director of Scientific Work to the Lancashire Sea-Fisheries Committee;

AND

\section{ROBERT A. DAWSON,}

LONDON: GEORGE PHILIP \& SON, LTD., 32 FLEET STREET, E.C. LIVERPOOL: 45 TO 5 I SOUTH CASTLE STREET. 


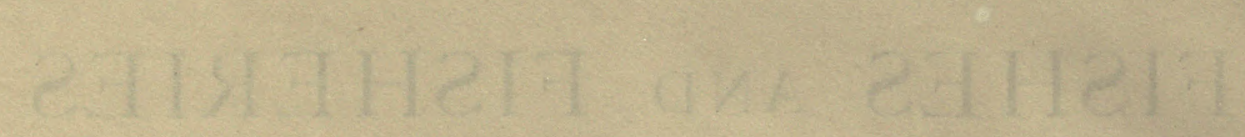

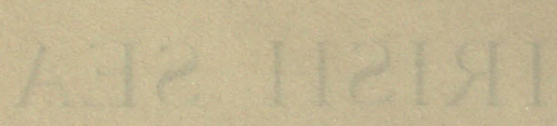




\section{$k-Q L 6=$

\section{Dedication.}

The fisst of these Memoirs was dedicated to Mr. John Fell, the first and only Chairman of the Lancashire Sea-Fisheries Committee, and at present Chairman of the Lancashire and Western Committee. We desire to dedicate this second Memoir

To

\section{THE MEMBERS OF THAT JOINT COMMITTEE,}

who have known and approved of our work in the District, and to whom, both individually and collectively, we are indebted for much valuable support and encouragement. We wish to dedicate this book to the Members of the Committee because we trust that some parts of its contents may, on occasions, be a help to them, and that it may fill a want as a work of reference on the Fish and Fisheries of the District. That it may be of use to Fishermen and others at home, and of interest to Sea-Fisheries Authorities and scientific men abroad, is the sincere hope of the Authors.

W. A. HERDMAN, R. A. DAWSON.

December, 1901 



\section{CONTENTS.}

I. INTRODUCTION

II. THE PHYSICAL FEATURES OF THE IRISH SEA - - . 4

I. AREA -

2. DEPTH - - - - - - - -

3. Rivers and Estuaries - $\quad$ - $\quad$ - $\quad$ - 6

4. Temperature - -

5. Specific Gravity - $\quad$ - $\quad$ - $\quad$ - 6

6. Tides and Currents - $\quad$ - $\quad$ - $\quad$ - $\quad$ - 7

7. The Вотtом Deposits -

III. DISTRIBUtion OF FISH, \&c., IN THE IRISH SEA - 20

IV. THE FISHES OF THE IRISH SEA - _ _ . . . 32

PISCES, ${ }^{*}$ \&C. (classified Zoologically) - _ _ _ _ _ _ 32

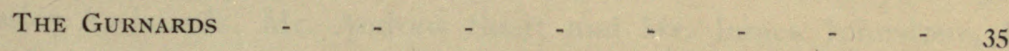

The Mackerels -

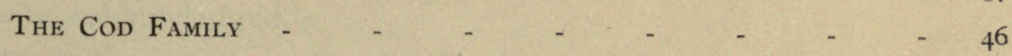

The Flat-Fish Family - $\quad$ - $\quad$ - $\quad$ - $\quad$ - 49

The SAlmon Family _

The Herring Family -

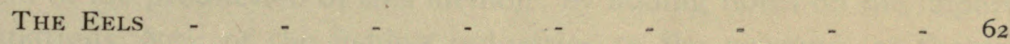

Sharks AND Dog-Fish -

SKATES AND RAYS - $\quad$ - $\quad$ - $\quad$ - $\quad$ - $\quad$ - $\quad$ - 65

V. THE LANCASHIRE AND WESTERN SEA-FISHERIES DISTRICT: ITS REGULATIONS AND ADMINISTRATION - - - 70 APPENDiX I. Draft Bye-laws of the District - _ _ $\quad$ - 8 i APPENDIX II. Tables SHowing Results of Hauls - _ $\quad$ - $\quad$ - 85

* Only a few of the more important Families, from the commercial point of view, are mentioned in this contents. 



\section{FISHES AND FISHERIES OF THE IRISH SEA.}

\section{I.-INTRODUCTION.}

The list of Fishes of the Irish Sea upon which this Memoir is founded, was commenced by one of us (W, A. H.) some 15 years ago, in connection with the work of the Liverpool Marine Biology Committee; and a first rough list, giving the scientific and the English names of all the fishes then known to inhabit the district, was printed as an appendix to the first "Lancashire Sea-Fisheries Laboratory Report" in 1892 , and was re-published, with some additions, in the "British Association Report" for 1896 . A manuscript laboratory list was then started, and has been added to from year to year. The help of our Fisheries Assistants, Mr. Andrew Scott and Mr. James Johnstone, B.Sc., and of Mr. H. C. Chadwick, at Port Erin, and of Mr. R. L. Ascroft, at Lytham, in adding to the list, are gratefully acknowledged.

But the mere list, with remarks upon distribution and life-history, however desirable from the scientific point of view, would have had comparatively little value from the "Fisheries" side. Consequently the Zoologist proposed to his colleague the Fisheries Expert (R. A. D.) to join in the production of this memoir, by adding notes on the importance, seasons, methods, fluctuations, \&c., of the fishing industries to the accounts of those fishes of the district which are of economic importance. To this Herdman has added the INTRODuction, and the short account of the physical features and of the clistribution of living things in the Irish Sea, while Dawson gives a concluding chapter on the constitution and administrative work of the Lancashire and Western Sea Fisheries District.

We are indebted to several friends for kind assistance in compiling the records of occurrence. Mr. A. O. Walker, F.L.S., while resident in Chester and at Colwyn Bay, paid close attention for many years to the movenents of fish and other animals in the estuary of the Dee, and along the north coast of Wales, including the catches in a fish weir on the shore at Rhos, near Llandrillo. He has kindly supplied us with various records taken from his notebooks from 1859 onwards. Mr. J. A. Clubb, M.Sc., of the Liverpool Free Public Museum, has, with the sanction of the Director, copied from the stockbooks the records of marine fishes found locally, and acquired by the Museum since 1857 . These amount to 26 species, most of which are fairly common, although a few are rare forms. These fishes were identified, we believe, by Mr. T. J. Moore, Corr. M.Z.S., who was Curator of the Museum from $185^{1}$ to 1892 . Professor P. J. White, of Bangor, has kindly supplied us with a list of the fishes he has observed in the Menai Straits, and with notes upon the 
occurrence of a few of the species. We are indebted to Mr. Ernest W. L. Holt, Scientific Adviser to the Fisheries Branch of the Department of Agriculture, for information about some of the rarer species, to which he had paid special attention.

We have records in all of 141 species of fishes which have been found in the Irish Sea.

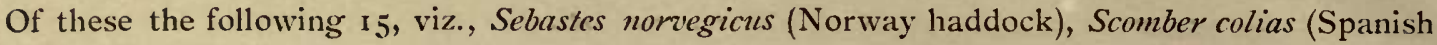
mackerel), Orcynus thynnus (Tunny), Thynnus pelumy's (Bonito), Echeneis remora (Remora), Lampris lunu (King-fish), Caranx trachums (Horse-mackerel), Xiphias gladius (Sword-fish), Scicena aquila (Shade-fish), Exocatus evolvans (Flying-fish), Orthagoriscus mola (Sun-fish), Zygcena malleus (Hammer-shark), Alopius vulpes (Thresher), Torpedo nobiliana (Torpedo), and Try'gon pastinuca (Sting-ray), must be considered as Oceanic or foreign fishes which only occasionally or accidentally visit our seas. They cannot be regarded, therefore, as contributing to our markets. Then a considerable number, about 85 species, are small or inedible fish, which are not clealt with by fishermen or fishmongers. But it must not be supposed on that account that they are of no economic importance. They all have their food, and their enemies and competitors ; some serve as food for larger fish, and many may exercise an important influence on living things around them. As examples of these non-marketable fish may be given:-Agonus cataphractus (Pogge), Lophius piscatorins (Angler), Solea lutea (Solenette), and the various species of Gobies, Blennies, Pipe-fish, and Dog-fishes. That leaves about $4 \mathrm{I}$ edible and marketable species, as follows :-Labrax lupus (Bass), Mullus barbatus (Red mullet), Sparus centrodontus (Sea bream), Trigla pini (Red gurnard), $T$. lucerna (Yellow gurnard), T. gurnurlus (grey gurnard), Scomber scombrus (Mackerel), Zeus fuber (John Dory), Mugil chelo (Grey mullet), Gadus callarias (Cod), G. aglefinus (Haddock), G. merlungus (Whiting), G. virens (Saithe), G. pollachius (Pollach), Merluccius anlgaris (Hake), Molva vulgaris (Ling), Hippoglossus vulgaris (Halibut), Rhombus maximus (Turbot), R. laevis (Brett), Lepidorhombus megastoma (Megrim), Pleuronectes platessa (Plaice), $P$. microcephalus (Lemon dab), P. limanda (Dab), P. flesus (Flounder), P. cynoglossus (Witch), Solcu aulgaris (Sole), Salmo salar (Salmon), S. trutta (Sea-trout), S. furio (Trout), Osmerus cperlunus (Sparling), Belone vulgaris (Garfish), Engruulis encrasicholus (Anchovy), Clupea harengus (Herring), C. sprattus (Sprat), C. pilchardus (Pilchard), C. finta (Shad), Anguilla anlgaris (Eel) Conger anlgaris (Conger eel), Acipenser sturio (Sturgeon), Raiu batis (Blue skate), and $R$. clavata (Thornback). Considerably less than a third of the total number of kinds of fishes in our sea are marketable. Of course many, or most, of the others are edible, and some are no doubt occasionally eaten; but the list given above shows those that form the subject of our fishing industries, and which appear in our markets.

D. S. Jordan* has divided the shore fishes of the Eastern Atlantic province into the following minor faunas:-The Icelandic, the British, the Mediterranean, the Guinean, and the Cape fauna. Consequently our British fish fauna lies between the Icelandic to the north and the Mediterranean to the south, and receives contributions from both as well as stragglers from the pelagic or open-sea fauna (such as the mackerel), or even from areas further afield-the Arctic and the more northern of the western Atlantic regions.

Our British fauna is, of course, mainly that of north-west Europe, and Moebius and Heincke's "Die Fische der Ostsee," and Fries, Ekström, and Sundevall's "History of Scandinavian Fishes," to the north of us, and Sauvage and Giard's "Catalogue des Poissons du Boulonnais" to the south, and other lists of the fishes of neighbouring continental 
coasts show, as is naturally to be expected, mainly the same as our list of species. Some of our species have a very wide range through the seas of the world.

The leading works upon British Fishes, or upon sections of the subject, which we have made use of, and from which we have drawn some of our records, are:-Yarrell's "History of British Fishes," (1836,) Couch's "Fishes of the British Isles," (1865,) and Day's more recent work "The Fishes of Great Britain and Ireland," (1884); then, Parnell's "Fishes of the District of the Forth," (1838), McIntosh's Marine Invertebrates and Fishes of St. Andrews, (1875), Byerley's "Fauna of Liverpool," (1854), and numerous smaller papers and lists by Eyton, Walker, Kermode, T. Scott, Brook, Fulton. Holt, Günther, Cunningham, and others, in the "Zoologist," the "Annals and Magazine of Natural History," and other Natural History Journals, and in the publications of the Fishery Board for Scotland, and the Marine Biological Association at Plymouth. We have also consulted the recent works by McIntosh and Masterman, on "Life Histories of the British Marine Food Fishes"; by McIntosh, in the "Resources of the Sea"; and by Cunningham, on "Marketable Marine Fishes of the British Islands."

Of those works which deal with the whole range of the subject, the most complete, the most authoritative, and the most generally useful, is Day's "Fishes of Great Britain." This work gives a description and a figure of every species of fish, marketable or not. To have added descriptions and figures to the present memoir, would have unduly increased its size, and is quite unnecessary, in most cases, when we have Day's work to consult. We have therefore considered it useful to place after the name of each species of fish in the following list, a reference to the page and to the plate where that fish will be found in Day's "British Fishes." In some few cases where the species is not described in Day's work, or where some other figure is a more adequate representation, we have given another reference, our object being to give, for the benefit of those who require it, a reference in the-case of each species to some good figure and description of that fish.

As this is a local list, mainly intended to be used locally, we think it desirable to note, on the next line after the reference to Day's work, whether or not the species is represented in the collection of local fishes in the Museum of the Zoological Department of University College, Liverpool. We also give the chief local names for each well-known species. 


\section{II.-PHYSICAL FEATURES OF THE IRISH SEA.}

I. AREA.

The Irish Sea is roughly a large quadrangular area lying between latitudes $5^{\circ}$ and $55^{\circ}$ North, and longitudes $3^{\circ}$ and $6^{\circ}$ West. Its northern wider part, in the centre of which the

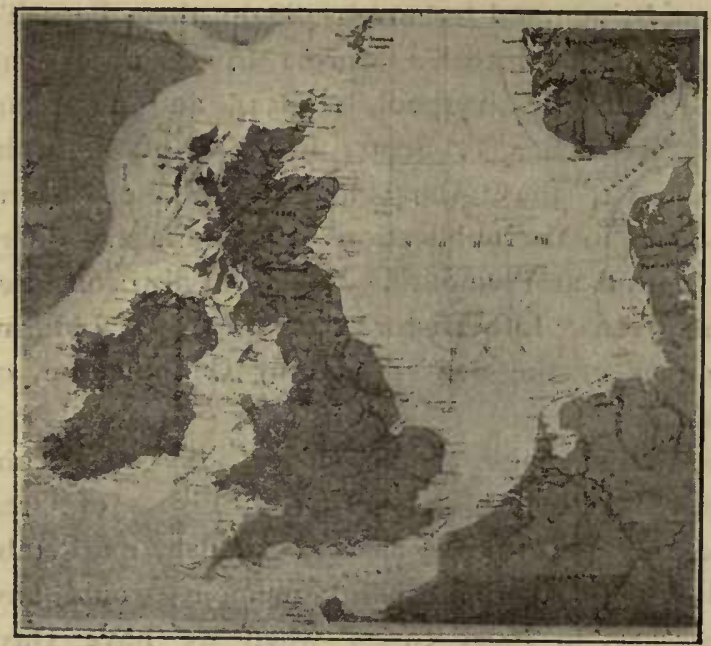

Fig I. Isle of Man lies, is bounded by Scotland, England, Wales, and Ireland, and forms a rude square, averaging rather more than 100 miles each way, and containing slightly over 10,000 square miles of surface. The narrower southern portion, between Wales and Ireland (Fig. I), is about 100 miles in length to St. George's Channel (lat. $52^{\circ} \mathrm{N}$.), and varies in width from about 50 to nearly 100 miles in Cardigan Bay. Its area, as determined with the "Amsler" planimeter is 7,246 square miles. Important extensions in the northern area are the Solway Firth, Morecambe Bay and Liverpool Bay, and in the southern part Carnarvon Bay and Cardigan Bay. The whole area, reckoned from the Mull of Galloway to St. David's Head, contains about 17,250 square miles, and has a coastline, not including estuaries, of about 850 miles. Although communicating with the North Atlantic, round the north and south of Ireland, by the North Channel and St. George's Channel, these entrances form together only about one-tenth of the circumference of the area ; and so the Irish Sea may be regarded as a landlocked or inland sea, surrounded on all sides by British territory. In this respect the Irish Sea is unique. There is, at least in Europe, no other sea of equal extent so completely closed in where the bounding territorial waters belong to one nation. Consequently the Irish Sea seems peculiarly well fitted for those experiments in Fisheries administration and cultivation which depend upon identical fisheries regulations. The territorial waters and the ports of this large area are all under British jurisdiction: no international questions are involved. Although at present in parts under different regulations, and controlled by different local authorities, it would only require a certain amount of mutual accommodation and arrangement between the English District Committees, the Irish Department of Agriculture, the Fishery Board for Scotland, and the Manx Fisheries Committee, to ensure uniformity of regulation and administration, and, what is at least as important, an identical scheme of observation and investigation over the whole area.

\section{DEPTH.}

Furthermore, the physical conditions are very varied. The greatest depth exceeds roo fathoms, and there is a very considerable area of over 5 o fathoms in depth, which forms a deep channel running throughout the length of the Irish Sea to the west of the Isle of Man, and communicating by means of the North Channel with the deep water of the Clyde sea area and off the west of Scotland, and by St. George's Channel with the floor of the North Atlantic south and west of Ireland. This deep channel varies in width from 4 to 24 miles, and there 
is probably an area of about 1,298 square miles of over 50 fathoms in the Irish Sea. On the western side the sea-bottom rises comparatively steeply from the deep channel to the Irish coast, but on the eastern side there is a great plateau between the Isle of Man and England (see Fig. 2). Water of over 30 fathoms in depth extends in from the west both to the north and, especially, to the south of the Isle of Man, forming depressions in an otherwise shallow area that are important spawning grounds for fishes. These separate the Isle of Man, by moderately deep water, from Scotland to the north, and from Anglesey to the south, leaving it

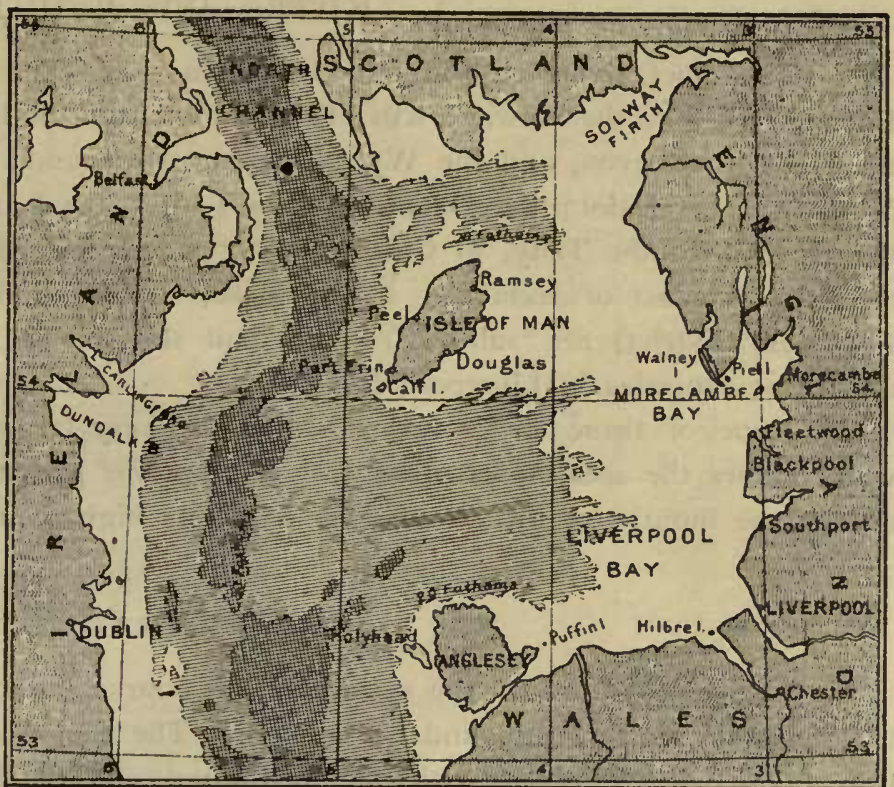

FIG. 2.

united to the northern part of Lancashire by a broad area of shallow water, which is scarcely in any part deeper than 20 fathoms. If, then, the floor of the Irish Sea were to be raised by that amount, 20 fathoms, the Isle of Man would be united by continuous land with England, and would still be separated by a wide and deep channel from Ireland. The section shown in Fig. 3 , where, to save space, the vertical scale is much greater than the horizontal, brings out

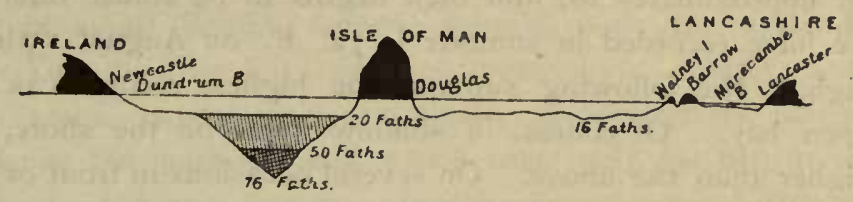

Fig. 3 .

clearly this contrast between the depths in the eastern and western parts of our area.

The region in which most of our work, both in the way of zoological investigation and in taking fisheries statistics, has been done is the shallow water off the Lancashire and Cheshire coasts, extending as far as Anglesey in one direction, and the Isle of Man in another (see Fig. 4). This area has along its eastern and southern sandy shores a belt of shallow water which is probably quite exceptional in the amount of Shrimps (Crangon vulgaris), of immature food fishes (mostly Pleuronectidæ), and of Cockles (Cardium. edule) which it contains. The ro-fathom line is on the average about 10 miles from land, and the area of shallow water within that line is about 2,og I square miles, while from the ro-fathom to the 2o-fathom line encloses an area of about $2,88_{5}$ square miles,

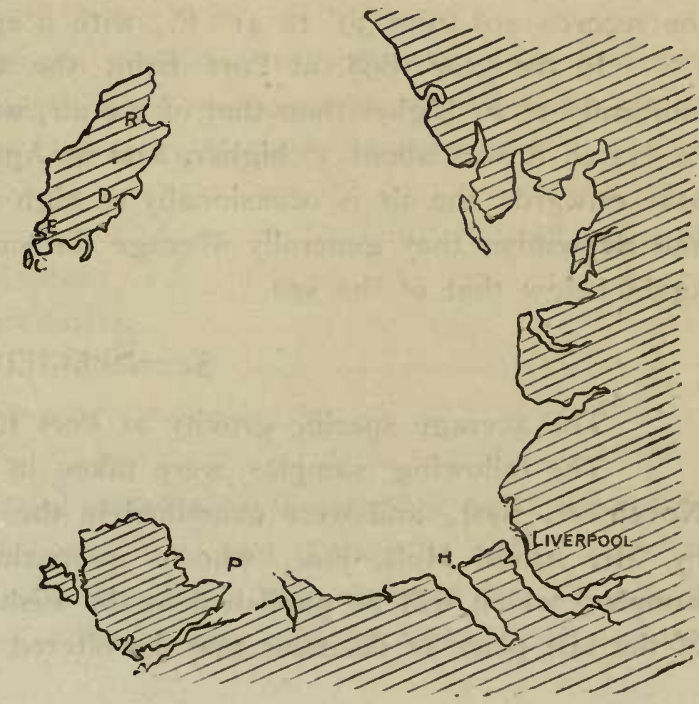

FIG. 4 . 


\section{Rivers and Estuaries.}

The chief rivers entering the Irish Sea are :-The Nith, the Annan, the Esk, and the Eden, falling into the Solway Firth ; the Derwent, and the Duddon, in Cumberland ; the Lune, the Kent, the Leven, and the Wyre, entering Morecambe Bay; the Ribble, at Preston; the Mersey, at Liverpool ; the Dee, at Chester ; the Clwyd and the Conway, in North Wales; the Dovey and the Teify, in Cardigan Bay; and the Slaney, the Liffey, and the Boyne, on the east coast of Ireland. All of these, and some smaller ones (23 in all in our Sea Fisheries District) are salmon rivers; and the Ribble, the Mersey, and the Dee form important estuaries in Liverpool Bay.

None of these rivers are, however, of very large size, no great volume of fresh water enters the area, and consequently the specific gravity, except actually in the estuaries and at the mouths of the streams, is relatively high, being generally at least $\mathrm{I}^{\circ} \mathbf{0 2} 5$.

\section{Temperature.}

The temperature of the sea-water, of course, varies much in the district, according to the depth, the locality, and the season. The temperatures of air and sea-water have been taken with regularity twice a day for years at the Marine Biological Station-at first on Puffin Island, and for the last ro years at Port Erin.

The lowest temperature recorded in winter is $37^{\circ} \mathrm{F}$. in February, 1898 and 1900, and the records show clearly how, during the greater part of spring and summer, before the maximum has been reached, the temperature of the sea lags behind that of the air, until, in September, the air approximates to, and then begins to be colder than the sea. The highest temperature we have recorded in summer is $7 z^{\circ} \mathrm{F}$. on August ${ }^{5} 5^{\text {th }}, 1893$, but that was exceptionally high. The following summer the highest record was $62^{\circ} \mathrm{F}$. These records are for the open bay. Of course, in shallow water on the shore, on some days, the temperature is higher than the above. On several occasions in front of the Laboratory it has reached $76^{\sim} \mathrm{F}$.

During March and April, while fish hatching was going on, the water in the hatchingboxes at Port Erin was found to range from $5^{\circ}$ to $53^{\circ} \mathrm{F}$., with a specific gravity of from $\mathrm{I}^{\circ} \mathrm{0} 265$ to $\mathrm{I} \cdot 0270$; while at Piel, in the Barrow Channel, at the same time of year, the records are from $39^{\circ}$ to $4 \mathrm{I}^{\circ} \mathrm{F}$., with a specific gravity of $\mathrm{I}^{\circ} \mathrm{0} 25^{8}$ to $\mathrm{I}^{\circ} \mathrm{0} 268$.

In the year 1898 , at Port Erin, the temperature of the sea in January was nearly uniformly $2^{\circ} \mathrm{F}$. higher than that of the air, while in February it averaged $4^{\circ}$ to $5^{\circ} \mathrm{F}$. higher. In March it was about $3^{\circ}$ higher, and in April the difference was reduced to $I^{\circ} \mathrm{F}$. Frong May onwards, the air is occasionally as high as or even higher than the sea, and in August and September they generally average the same. Then the air temperature begins to fall again below that of the sea.

\section{5.-Specific Gravity.}

The average specific gravity at Port Erin is about 1.0260 .

The following samples were taken in different parts of the district, in October and November, 1901, and were examined in the Zoological Laboratory, at University College, by Mr. Alfred Holt, jun., who is preparing a detailed paper upon these and other samples, which will be published in the Fisheries Laboratory Report for 1901. The value of the last place of decimals may be altered in some cases in that fuller paper. 


\begin{tabular}{|c|c|c|c|c|c|c|}
\hline LOCALITIES. & 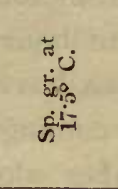 & 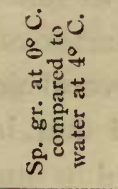 & 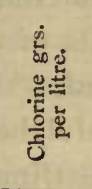 & 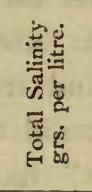 & 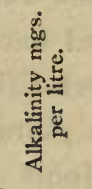 & 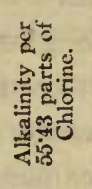 \\
\hline New Brighton .............. & $1 \cdot 02476$ & $1 \cdot 02605$ & $17 \cdot 25$ & $31 \cdot 17$ & $51 \cdot 20$ & $\cdot 1646$ \\
\hline Piel (Barrow Channel) .................. & $1 \cdot 02516$ & 1.02647 & 17.88 & $32 \cdot 30$ & $53 \cdot 66$ & $\cdot 1663$ \\
\hline Port Erin (High water after rain) & 1.02585 & 1.02719 & $18 \cdot 23$ & $32 \cdot 94$ & $54 \cdot 97$ & $\cdot 1672$ \\
\hline Port Erin (Low water) ……........... & $1 \cdot 02582$ & $1 \cdot 02716$ & 18.28 & $33 \cdot 03$ & $53 \cdot 0$ & $\cdot 1608$ \\
\hline Fleshwick (High water) ........ & $1 \cdot 02594$ & $1 \cdot 02729$ & $18 \cdot 41$ & $\begin{array}{ll}33-26 \\
33-1\end{array}$ & 53.2 & . 1600 \\
\hline Crosby Channel (1 hour flood) & $1 \cdot 02337$ & $1 \cdot 02459$ & 16.56 & 29.02 & $55: 5$ & $\cdot 1857$ \\
\hline 1 mile N. of Bar Lightship (Low water) & $1 \cdot 02527$ & $1 \cdot 02658$ & 18.0 & & $54 \cdot 29$ & $\cdot 1667$ \\
\hline Blackpool ............................... & $1 \cdot 02390$ & 1.02514 & & 30 & $55 \cdot 93$ & $\cdot 1778$ \\
\hline Landing Stage (High water) & 1.02313 & 1.02433 & $16 \cdot$ & $29 \cdot 99$ & $51 \cdot 74$ & $\cdot 1728$ \\
\hline 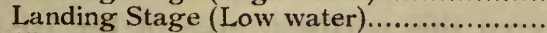 & $1 \cdot 01631$ & $1 \cdot 01714$ & $11: 3$ & $20 \cdot 46$ & $51 \cdot 11$ & 2500 \\
\hline 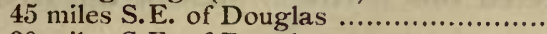 & $1 \cdot 02572$ & 1.02713 & $18 \cdot 50$ & $33 \cdot 42$ & 55.57 & $\cdot 1672$ \\
\hline 30 miles S.E. of Douglas & 1.02606 & $1 \cdot 02741$ & $18 \cdot 54$ & $33 \cdot 49$ & 54.00 & $\cdot 1615$ \\
\hline 15 miles S.E. of Douglas . & $1 \cdot 02601$ & $1 \cdot 02736$ & $18 \cdot 45$ & $33 \cdot 33$ & $52 \cdot 38$ & $\cdot 1574$ \\
\hline Douglas (Low water)....... & $1 \cdot 02572$ & $1 \cdot 02706$ & 18.49 & $33 \cdot 40$ & $54 \cdot 29$ & $\cdot 1628$ \\
\hline
\end{tabular}

\section{6.- Tides and Currents.}

In connection with the investigation of the surface life, in discussing the appearance and disappearance of swarms of certain Copepoda and Medusæ, and in considering the possible influence of the movements of food matters upon the migration of fishes, we tried some years ago by means of small "drift bottles" to ascertain the set of the chief currents, ticlal or otherwise, such as the movement of surface waters caused by prevalent winds. The Prince of Monaco started a few years before that the system of distributing over the North Atlantic large numbers of small floating copper vessels, with the object of finding out where they drifted to. This plan we have adopted, with slight modifications. In September, 1894, we selected a small, strong, buoyant bottle, measuring $7.5 \mathrm{~cm}$. by I.8 cm., which seemed well suited for the purpose, and which costs only $7 \mathrm{~s}$. per gross. We afterwards adopted a rather larger size of bottle, $8.5 \mathrm{~cm}$. in length, and substituted stamped and addressed postcards for the slips of paper, as getting rid of various postal difficulties that had occurred. I drew up a notice, as follows, to go in the bottles, and had a large number printed and numbered consecutively :-

NoticE-Anyone who finds this is earnestly requested to write the place, and date when found, in the space on the other side for the purpose, place the paper in an envelope, and post it to Professor Herdian, University College, Liverpool.

Postage need not be prepaid.

No

[OTHER SIDE.]

[Turn over.

Please write distinctly and give full particulars.

Locality, where found

Date when found.

Name and address of sender

A paper was then placed in each bottle, so folded that the number could be readily seen through the glass, the cork was well pressed down, and dipped in melted paraffin. Nearly two thousand of these bottles have, since that date, been dropped into the sea in various parts of our area, a record being kept of the locality and time when each was set 
free. Dozens were let off from time to time from the Isle of Man steam in crossing to Douglas and back, at intervals of quarter of an hour, and from our trawlers when dredging between Port Erin and Ireland. Several dozen have been let off from Mr. Alfred Holt's steamers in going round to Holyhead and in coming down from Greenock. Our fishery steamer "John Fell" has distributed a number along the coast in the northern part of the district, and others have been set free at stated intervals during the rise and fall of the tide from the Morecambe Bay Light Ship in the northern part of our area, north of the "head of the tide," and from the Liverpool North-west Light Ship to the south of the "head of the tide." Others, finally, have been despatched by Mr. R. L. Ascroft, by Mr. Andrew Scott, and by various members of the Committee in other parts of the area from small boats and on our dredging expeditions, in some cases, between the Isle of Man and Ireland. Altogether we have pretty well covered this northern area of the Irish Sea in our distribution of floating bottles.

The details of the bottles found and returned have been reported on in our Laboratory Reports for 1895 and 1896 , from which we copy the following particulars :Over 42 per cent.-more than 2 out of every 5 -of the bottles have come back to us. They come from various parts of the coast of the Irish Sea-Scotland, England, Wales, Isle of Man, and Ireland. Some of the bottles have gone quite a short distance, having evidently been taken straight ashore by the rising tide; while others have been blown ashore by the wind, e.g., two (post cards 2 I I and 214) let off near New Brighton stage on 9th October, I895, the tide ebbing and the wind N.N.W., were found next day near the Red Noses, I mile to the west. Others have been carried an unexpected length, e.g., one (No. 35), set free near the Crosby Light Ship, off Liverpool, at $12.30 \mathrm{p} . \mathrm{m}$., on October Ist, was picked up at Saltcoats, in Ayrshire, on November 7 th, having travelled a distance of at least 180 miles* in thirty seven days; another (H. 20) was set free near the Skerries, Anglesey, on October 6th, and was picked up one mile north of Ardrossan, on November

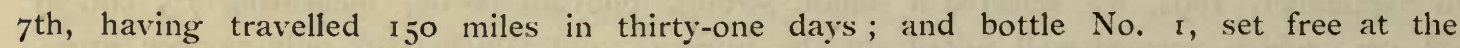
Liverpool Bar on September 30 , was picked up at Shiskin, Arran, about $16_{5}$ miles off, on November 12 th. On the other hand, a bottle (J. F. 34) set free on Norember 7 th, in the Ribble Estuary, was picked up on November I th at St. Anne's, having gone only 4 miles.

It may be doubted whether our numbers are sufficiently large to enable us to draw very definite conclusions. It is only by the evidence of large numbers that the vitiating effect of exceptional circumstances, such as an unusual gale, can be eliminated. Prevailing winds, on the other hand, such as would usually affect the drift of surface organisms, are amongst the normally acting causes which we are trying to ascertain. Mr. W. E. Plummer, of the Bidston Observatory, has kindly given us access to his records of weather cluring the periods in question, and we have noted opposite the bottles, from whose travels we are drawing any conclusions, an approximate estimate of the wind influences during the period when the bottle may have been at sea. There have been a few rather extraordinary journeys, e.g., one let off in the middle of Port Erin Bay, on April 23rd, was found at Fleetwood on July 6th ; another let off at Bradda Head, on June 3 rd, was found on Pilling Sands (near Fleetwood), on July 24 th.

* More probably, very much further, as during that time it would certainly be carried backwards and forwards by the tide. 
It is important to notice that the bottles may support one another's evidence, those set free about the same spot often being found in the same locality, $e . g$, , out of a batch of six set free off New Brighton, on Oct. $9^{\text {th }}$, 1895 , five have come back, and all were found at about the same place.

What is already well-known in regard to the tidal streams or currents in the Irish Sea, is that the tidal wave coming in from the open Atlantic reaches us mainly round the south of Ireland. The northern inlet is narrower, and admits only a comparatively small proportion of the total volume of water. For nearly six hours after low-water, at, say Liverpool, two tidal streams pour into the Irish Sea, the one from the north of Ireland, through the North Channel, and the other, the larger, from the southward, through St. George's Channel. Parts of the two streams meet and neutralise each other to the west of the Isle of Man, causing the large elliptical area, about 20 miles in diameter, and reaching from off Port Erin to Carlingford, where no tidal streams exist, the level of the water merely rising and falling with the tide. The remaining portions of the two tidal streams pass to the east of the Isle of Man, and eventually meet along a line extending from Maughold Head into Morecambe Bay. This line is the "head of the tide." During the ebb the above currents are practically reversed, but in running out the southern current is found to bear more over towards the Irish coast.

The tide at Liverpool reaches us about 8 hours after the same wave reaches Bristol, and an hour and twelve minutes later than it is at Holyhead. The tidal rise and fall at

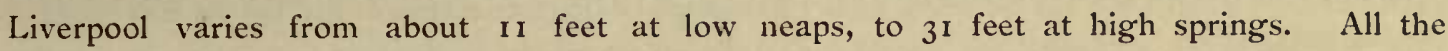
highest tides in our district occur at midday and at midnight, consequently the lowest spring tides, which are the best opportunities that the naturalist has for collecting marine animals on the shore, are about 6 a.m. and 6 p.m., an arrangement which allows of two tides a day being worked in summer, but prevents, on account of darkness, a really low spring tide from being seen during the winter half of the year.

There is some reason to believe that, as a result of the general drift of the surface waters of the Atlantic, and the shape and direction of the openings to the Irish Sea, more water passes out by the North Channel than enters that way, and more water enters by the South (St. George's) Channel than passes back, and that consequently there is, irrespective of the tides, a slow current passing from south to north through our district. The fact that so many of our drift bottles have crossed the "head of the tide" from S. to N., and that of those which have gone out of our district, nearly all have gone north to the Clyde Sea-area, supports this view, which we learn from Admiral Sir William Wharton, is a priori probable, and which is believed in by some nautical men in the district, from their experience of the drift of wreckage.

It may be objected to our observations by means of drift bottles that they are largely influenced by the wind and waves, and are not carried entirely by tidal streams. Well, that is an advantage rather than any objection to the method. For our object is to determine not the tidal currents alone, but the resulting effect upon small surface organisms, such as floating fish eggs, embryos and fish food, of all the factors which can influence their movements, including prevalent winds. The only factors which can vitiate our conclusions are unusual gales, or any other quite exceptional occurrences, and the only way to eliminate such influences is (I) to allow for them so far as they are known from the weather reports, and (2) to employ a large number of drift bottles and continue the observations over a considerable time. We have carefully considered the bearing of 
the weather records, and we think that the large number of bottles we have made use of ought to enable us to come to some definite results. Our conclusions so far then are :-

(I) A large number (over 42 per cent.) have been stranded and found and returned; (2) only a small proportion ( 33 per cent.) have been carried out of our part of the Irish Sea ; (3) nearly 12 per cent. have crossed the "head of the tide" showing the influence of wind in carrying floating bodies over from one tidal system into another; (4) most of the bottles set free to the west of the Isle of Man have been carried across to Ireland, only a small number $(3.8$ per cent.) of them have got round to the eastern side of the Island and been carried ashore on the English coasts ; $(5)$ the majority of the bottles set free off Dalby have gone to the Co. Down coast; $(6)$ a considerable number of bottles have been set free over the deep water to the east of the Isle of Man, where our more valuable flat fish spawn, and of those that have been returned, the majority had been carried to the Lancashire, Cheshire and Cumberland coasts. So we may reasonably conclude that the embryos of fish spawning off Dalby would tend to be carried across to the Irish Coast, while those of fish spawning in the deep water to the South and the South East of the Isle of Man would go to supply the nurseries in the shallow Lancashire and Cheshire bays, and possibly further north, and very few would be carried altogether out of the district. These nurseries, again, on the Eastern Coasts, it must be remembered, feed the offshore grounds and so benefit the Manx and the Irish and Welsh fisheries, and in fact the whole of the Irish Sea.

\section{7.-The Botrom Deposits}

1. The most extensive shallow-water deposit is sand. In most localities along the coasts of Lancashire, Cheshire, and North Wales, from the sea-shore out to the Io-fathom contour, the bottom is formed of more or less pure quartz sand. Occasionally in spots there are local patches of stones, of shells, or of mud; but these can generally be accounted for by tidal or estuarine currents, by the entrance of fresh-water streams carrying down alluvium, or by the presence of littoral or sub-littoral boulder clay. These spots are all, however, of small area, and the great extent of the bottom down to Io fathoms is sand.

2. Further out, however, between 10 and 20 fathoms, the sand becomes greatly mixed with mud, and much diversified by large tracts of shelly deposits or by patches of gravel, and the fauna on the bottom also becomes much more abundant. In some spots, at about 20 fathoms, it is made up over considerable areas almost entirely of Ophiuroids (Ophiocoma nigra and Ophiothrix fragilis), which fill the dredge haul after haul. At two localities off the Isle of Man, viz., along the east coast from Clay Head to St. Ann's Head, and off the west coast between Contrary Head and Niarbyl, at depths between 10 and 20 fathoms, are great nullipore deposits formed of Melobesic and Lithothamnion, which have a most characteristic appearance, smell, and fauna.

This area of the sea-bottom, from 10 to 20 fathoms, extends across from the north of Lancashire to the Isle of Man, so that opposite Barrow, for example, there is a wide extent of about 50 miles in length of sea-floor at depths of not more than 15 or 16 fathoms. The Isle of Man is connected with England by this plateau, and is separated from Ireland by deep water (see Fig. 3 above). 
3. Depths of over 20 fathoms are only found to the west, north, and south of the Isle of Man ; and depths of from 20 to $5^{\circ}$ fathoms give us the most varied bottom deposits and the richest fauna. As a rule, the sand is more or less mixed with mud, and, as the bottom goes deeper, the amount of mud gets greater. When there is a considerable admixture of mud with coarse sand it forms what is known to the trawlers as a "reamy" bottom, and that is the ground upon which the sole and some other fish are generally found spawning.

Shells and other hard parts of animals play an important part in the deposits at depths of about 20 fathoms and upwards. In places the dredge comes up filled with Pecten shells, dead and alive, chiefly $P$. opercularis and $P$. maximus. At other places the deposit is practically composed of the shells of Pectunculus glycimeris. These and other shell beds form a rich collecting ground to the naturalist, as they support an abundant and varied fauna. Zoophytes and polyzoa are attached to the shells, and these serve as shelter for nudibranchs and other small mollusca, worms, and ascidians. On the whole the heterogeneous deposits support a richer fauna than do the homogeneous deposits, such as sand or mud, and it is chiefly in the zone of depth we are now considering that the heterogeneous deposits occur.

4. The depths over $5^{\circ}$ fathoms contain a pure dark bluish-grey mud, which is very tenacious, and sets when dried into a firm clay. This is abominable stuff to dredge in and to work with on deck. It clings to everything that touches it ; it is almost impossible to see what is in it, and to get the animals out of it uninjured; it is too solid for the sieves, and the hose can be played upon masses of it almost indefinitely without dissolving it. The fauna of this zone is, in our district, quite peculiar and characteristic. In its shallower parts, about jo fathoms, it contains great numbers of living and dead Turritella terebra, upon many of which are attached one, two, or three specimens of the little red anemone, Sagartia expansa. In its deeper parts, up to 80 fathoms, are found Calocaris macundrece, Hyalinacia tubicola, a small Lumbriconereis, Panthalis oerstedi, Lipobranchius jeffreysii, Brissopsis lyrifera, Amphiura chiajii, and Isocardia cor. Numbers of large sausage-like muddy tubes, formed of stratified layers of interlacing threads of mucus in which the mud particles are closely entangled, are brought up in the dredge. These we have proved to be the tubes of Panthalis oerstedi, and the living annelid has several times been found in the tubes, but most of those we dredge up are empty, and the tubes are certainly far more numerous than the worms. Apparently the explanation is that the Panthalis forms a tube as it lies in the mud, and then when it moves away leaves its tube behind it (one can scarcely imagine the animal dragging such a tube through this tenacious deposit), and after a time forms another in a new situation.

These are the leading conclusions we have come to so far in regard to the distribution of sub-marine deposits in our area. Two further questions now present themselves : first, the biological one-the effect upon the fauna ; and secondly, the geological one-the origin of the deposits. In regard to the importance of the nature of the bottom to the animals living upon it there can be no doubt. Probably the nature of the deposit is the most important of the various factors that determine the distribution of animals over the sea-bottom within one zoological area. It is certainly more important than mere depth; a muddy bottom will support a similar fauna at ro fathoms in one place and at 50 fathoms in another. Probably the most important influence in the environment of a lower animal is its food, and once beyond the narrow sub-littoral zone in which algæ flourish-and to which, of course, certain phytivorous animals must be restricted-it is probably chiefly the nature of the bottom which 
determines the food.* Many animals feed upon the deposit, others browse upon the polyzoa and zoophytes which can only attach themselves and grow where there are sufficiently large objects, such as shell valves, from which they can get the necessary stability; while others, again, feed upon their neighbours, which subsist on the deposit or are attracted by the zoophytes, \&c. ; for example, soles are frequently caught upon ground (known to fishermen as "sole ground") where Flustra foliacea lives in abundance, and the probable connection is that the fish are dependent upon the numerous amphipoda and other small animals which frequent the tufts of Flustra. The same locality may vary so much from time to time in the temperature, the salinity, and the transparency of the water, that it is probable that none of these factors-so long as the variations do not exceed certain limits-have so much influence upon the bottom fauna as the nature of the deposit has. It is therefore quite to be expected that the fauna should vary from place to place with the nature of the bottom, and that is what we have observed frequently in our work round the Isle of Man. In practically the same water, identical in temperature, salinity, and transparency, at the same depth, with, so far as we know, all the other surrounding conditions the same, the fauna varies from place to place with changes in the bottom-mud, sand, nullipores, and shell beds, all have their characteristic assemblages of animals.

As to the further, and very important, question of the origin of the deposits, that is to a great extent a purely geological inquiry, and one which cannot, until we have accumulated a much larger series of observations, be fully discussed; but there are a few matters which may be briefly pointed out as giving some idea of the range and bearing of the question.

I. It is necessary to make a most careful examination of the deposits. For example, all muds are not the same in origin. A deposit of mud may be due to the presence of an eddy or a sheltered corner in which the finer particles suspended in the water are able to sink, or it may be due to the wearing away of a limestone beach, or to quantities of alluvium brought down by a stream from the land, or to the presence of a submerged bed of boulder clay, or, finally, in some places, to the sewage and refuse from coast towns.

2. We have kept in view the possibility of some correlation between the geological formations along the beach and the sub-marine deposits lying off the shore. There is no doubt that the nature of the rock forming the shore has a great influence upon the marine fauna, and has sometimes some effect upon the neighbouring deposits. For example, the contrast between the deposits lying off the two prominent headlands, the Great Orme, in North Wales, and Bradda Head, in the Isle of Man, is well marked. The Great Orme is composed of mountain limestone, and the result of its weathering and erosion is that large blocks are found lying scattered outside its base on the fine sand; but there is no deposit of smaller stones, gravel, and resulting sand farther out, probably because in the wearing of the rock and large detached blocks by the sea a great deal is removed in solution and the rest in suspension as very fine mud-this we have found to be the case round Puffin Island, which is also mountain limestone. Bradda Head, on the other hand, is a schistose metamorphic silurian rock, which breaks up into large fragments,

* The only food supply quite independent of the bottom is dead plankton, from the water above, which may reach the bottom uneaten; and possibly a small amount of decayed vegetation and other organic matters brought down by rivers from the land, and some of which may reach the sea-bottom, 
and these into smaller, and so forms deposits of dark slatey more or less angular gravel, and then very coarse sand, extending for some way out from the foot of the cliff.

The influence of the shore rocks upon the littoral fauna is an important subject upon which we have accumulated some observations; but the matter requires further work and detailed discussion, and must be left over for a future occasion.

3. Probably the great bulk of the silicious sand which forms so large a part of the floor of our sea is derived proximately-whatever may have been its ultimate

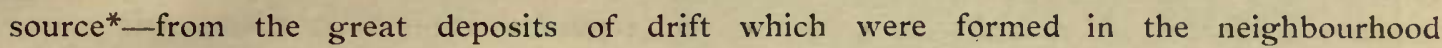
during the Glacial period, and large tracts of which may since have been broken up by the sea.

4. As examples of a few peculiar and specially noteworthy deposits, which are not simply "terrigenous" in their origin, the following may be mentioned:-

South-east of the Calf-sound, about two miles out, at a depth of 20 fathoms, there is a white shelly sand which seems to be almost wholly composed of animal remains. There are broken fragments of the lamellibranchs Pecten, Anomia, Pectunculus, Mactra, Venus, and Mytilus; of the gastropods Cyprau, Buccinum, Emarginula, Purpura, and Trochus; of various calcareous polyzoa, such as Cellaria fistulosa, Cellepora pumicosa, and lepralids; of Balanus and Serpula, and of various echinoderm plates and spines, and the whole shells of Echinocyamus pusillus. The deposit, when it comes up in the dredge, is of a gleaming whiteness, and has a very characteristic appearance. Such a deposit as this would form a rock almost wholly made up of fossils, and might compare well with some Tertiary fossiliferous deposits, such as the Coralline Crag.

A little further north, along the east coast of the Isle of Man, at about a corresponding depth and distance from land, we meet with a purely vegetable deposit formed of the nullipores Lithothamnion and Melobesia. On the other side of the island, again, between Port Erin and the Calf, at a depth of 18 fathoms, there is a tract of sea-bottom which, when brought up on deck, looks, at the first glance, like a peculiarly fibrous sand, but a closer examination shows that it is entirely composed of the comminuted plates, and especially the spines, of echinids, chiefly Spatıngus. We do not remember to have met with a reference to material such as this either amongst recent or fossil deposits.

There is another interesting deposit found in at least two localities on the sea-floor in our district, the one between the Calf and Holyhead, and the other off King William's Bank, between Ramsey and St. Bees. The deposit takes the form of irregular calcareous masses (Fig. 5), cementing together the dead shells and sand grains which are lying on the bottom, and making lumps like "clinkers." Hence one spot where it is found is called by the Manx trawlers the "Blacksmith's Shop," the Fleetwood trawlers call it the "Smithy." It is about 25 miles S.S.W. of the Calf of Man ; in ordinary clear weather the Chickens' Rock Lighthouse just dipping, and the Stack at Holyhead just rising above the water, and the depth is about 25 fathoms. We first heard of this interesting material from Mr. W. Beck, of Douglas, and he kindly sent a specimen for us to Mr. A. Leicester, at Port Erin. Mr. Leicester found the following shells in the concretion:-Pecten opercularis, Cyprina islandica, Venus lincta, Cardium echinatum, Nucula mucleus, Scrobicularia alba, Lucina borcalis, and Turritella terebra. We have obtained other specimens since. There is a fine 


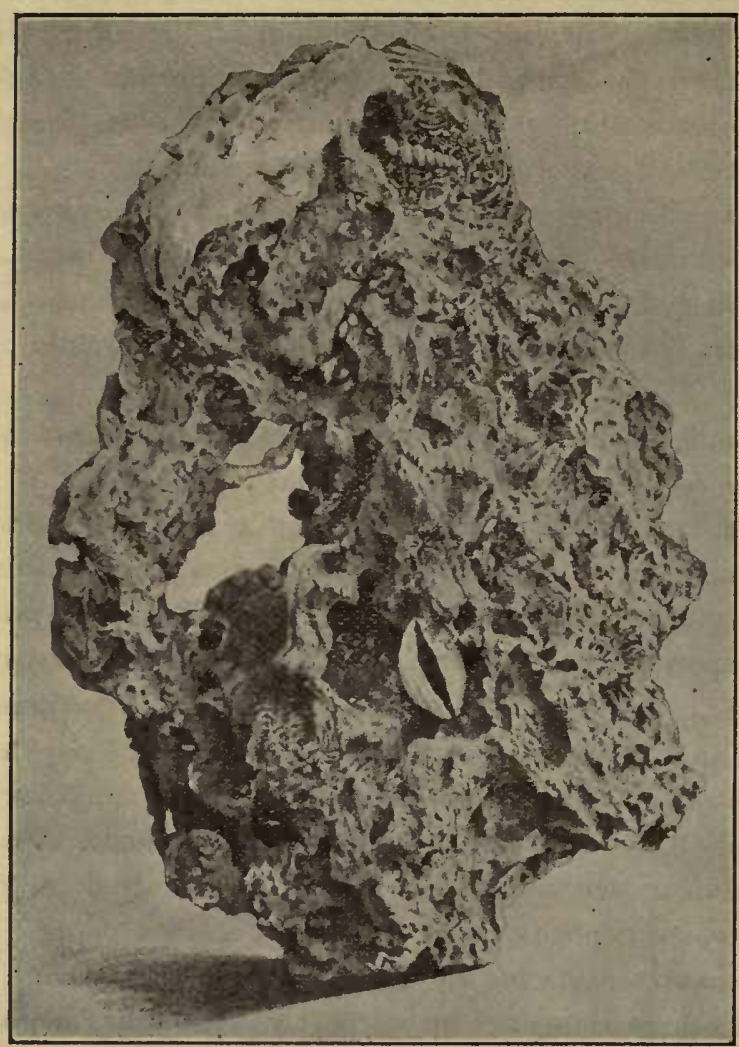

F1G. 5. lump in the Biological Station at Port Erin, and we have presented another piece to the Jermyn Street Museum in London. Mr. W. W. Watts, F.G.S., has made a careful examination by thin sections of the latter specimen, and he has kindly sent us the following notes in regard to it:- "The microscopic examination shows that it is practically a fine grained grit made up of the usual constituents of fragmental rocks cemented together, the cement being in greater quantity than the grains.

"These grains are chiefly chips of quartz, but I have also seen microcline, orthoclase felspar, plagioclase felspar, brown mica, a few grains of glauconite, and green and brown pseudomorphs, probably after grains of some ferromagnesian mineral like augite hornblende, or even possibly olivine, which it is impossible now to say; but I think most probably hornblende. There are one or two quite opaque grains, and several clear grains containing a good deal of minute magnetite. The grains vary in

size within small limits, the largest I have measured is 0.02 inch, and the smallest 0.002 inch ; but the average size would be about $0.004-0.005$ inch in longest diameter. They are, therefore, minute grains, and, as might be expected, extremely angular, not one in a hundred showing rounded outlines. They are chiefly such grains as would come from the denudation of granitic rocks or sediments derived from them.

"The cement is carbonate of lime, with a small impurity of carbonate of iron, present chiefly in certain layers, but not there in any considerable quantity. The cement is clearly crystalline in immediate contact with the grains, and also where lining cracks and cavities. Elsewhere it is more opaque, and is conspicuously crystalline. The section cuts across numerous shell fragments and a few polyzoa, and where there are any hollow structures, as in the inside of Lamellibranchs or Gastropods, they are filled up with a substance indistinguishable from the bulk of the concretion.

"The specimen shows no particular reason for the local deposit of cement, and the other constituents are doubtless the ordinary materials of the sea-bed. I cannot find any evidence that the cementing is due to any organic agency, and the thoroughly well developed crystals of carbonate of lime quite agree with this. It may be that the carboniferous limestone crops out on the sea bottom under the deposit, and if so there would very likely be submarine springs laden with carbonate of lime which might be precipitated there under less pressure or local loss of carbonic acid. It may be added that Mr. Clement Reid could not see in the specimen any identifiable shells of other than recent age," 
Sample bags of all the more important sub-marine deposits we have come upon have been sent, at Sir Archibald Geikie's request, to the Museum of the Geological Survey in Jermyn Street. They have been examined there by Mr. Clement Reid, F.G.S., who writes as follows in regard to them :-

" On comparing these samples with British deposits of Tertiary date, one finds a marked difference in lithological character. Dredgings from the Irish Sea, and also from the North Sea, are characterised by a much coarser and more gravelly texture than one would expect at such depths-coarser, in fact, than one finds in Pliocene deposits yielding a similar fauna, indicating similar or even smaller depths. A glance at these dredgings shows the reason for this, for they are largely composed of unworn or little worn fragments of rock, often entirely encrusted by organic growth. The stones evidently have not been transported far by water, or they would be well rounded, like the pebbles found in our Eocene beds. The incrusting organisms show also that the fragments have lain undisturbed on the sea-bed, yet they have been derived from far-distant sources. Though no Glacial strix were observed, and no undoubted sub-fossil Arctic shells have yet been found at these localities, yet there seems little doubt that the bulk of the material on the sea-bottom over this area has been derived from the breaking up of pre-existing Glacial deposits. This may occur at a depth of several fathoms through the gradual washing away of the muddy and sandy matrix of a boulder clay or Glacial gravel. Coarse gravel is thus caused to accumulate at a spot where the currents may be too feeble to transport anything but sand.

"This sub-marine origin of angular gravel deposits should not be forgotten, for it affects the lithological character of the sea-bottom over most of the area which was formerly glaciated, even as far south as Cornwall. On the other hand, it does not affect, except to a small extent, the sea-bed beyond the former limit of the ice, and it does not affect pre-Glacial deposits. Thus we must always expect to find at similar depths the same fauna associated with deposits of finer texture as soon as we leave the glaciated area, or when we go back into Tertiary times.

"It is also worth noting that the occurrence of a stony bottom at 20 or 30 fathoms-where normally there would be no deposit coarser than sand-will probably lead to a disproportionate increase of all incrusting organisms, and of all organisms needing a solid base. This has certainly taken place, as anyone studying our shoal-water Tertiary deposits will have observed. They contain few stones, and though each stone or dead shell may be covered with incrusting organisms, yet the relative proportion of these to the free forms is far smaller than seems commonly to be the case in the seas that now wash our shores. The sole exception to this rule among the British Tertiary strata is found in the Coralline Crag, in which the contemporaneous consolidation of the limestone was sufficient to provicle the necessary solid base for the incrusting and fixed organisms so abundant in that deposit.

"Notwithstanding this peculiarity of most of the dredgings, a few samples may well be compared with our Older Pliocene (Coralline Crag). I would particularly draw attention to certain localities where material almost entirely of organic origin has been obtained. Of these perhaps the most interesting are some samples full of Cellaric fistulosa (found to the south-east of the Calf Sound, 20 fathoms). They are in many respects strikingly like certain parts of the Coralline Crag. The more ordinary type of Coralline Crag, with its 
extremely varied polyzoon fauna, we cannot yet match in British seas :* it was probably formed, as the mollusca indicate, in a sea several degrees warmer than ours.

"It was hoped that in the course of these dredgings some light might be thrown on the Tertiary strata underlying the bed of the Irish Sea, for in the North Sea the dredge occasionally brings up hauls of Tertiary fossils. This expectation has not yet been realized; but possibly, by dredging in the channels, where the submarine scour is greatest, such deposits may yet be reached. It is very important to obtain some knowledge of the Tertiary bed of the Irish Sea, for Irish Pleistocene deposits contain a considerable admixture of extinct forms, which may be derived from Tertiary deposits below the sea level. The Glacial Drift of Aberdeenshire contains Pliocene Volutes and Astartes, derived from some submarine deposit off the Aberdeenshire coast. The so-called 'Middle Glacial Sands' of Norfolk are full of shells which I now believe to be derived from some older deposit, probably beneath the sea."

One point which this collection of deposits from comparatively shallow shore waters seems to bring out is that the classification of submarine deposits into "terrigenous" and "pelagic," which was one of the earliest oceanographic results of the "Challenger" Expedition, and which is still adhered to in the latest "Challenger" volumes as an accepted classification, does not adequately represent or express fully the facts. Terrigenous deposits are supposed to be those formed round continents from the waste of the land, and are stated to contain on the average 68 per cent. of silica. Pelagic deposits are those formed in the open ocean from the shells and other remains of animals and plants living on the surface of the sea above, and they are almost wholly free from quartz particles.

Ordinary coast sands and gravels and muds are undoubted terrigenous deposits. Globigerina and Radiolarian oozes are typical pelagic deposits. But in our dredgings in the Irish Sea, where the deposits ought all, from their position, to be purely terrigenous, we meet with several distinct varieties of sea-bottom which are not formed mostly from the waste of the land, and do not contain anything like 68 per cent. of silica; but, on the contrary, are formed very largely of the remains of bottom-haunting plants and animals, and may contain as little as 17 per cent. of silica. Such are the nullipore bottoms, and the shell sand and shell gravel met with in some places, and the sand formed of comminuted spines and plates of echinoids which we have found off the Calf Island. These deposits are really much more nearly allied in their nature, and in respect of the kind of rock which they would probably form if consolidated, $\uparrow$ to the calcareous oozes amongst pelagic deposits, than they are to terrigenous deposits, and yet they are formed on a continental area close to land in shallow water. Moreover, although agreeing with the pelagic deposits in being largely organic in origin, they differ in being derived not from surface organisms, but from plants (the nullipores) and animals which lived on the bottom. Consequently the division of deposits into "terrigenous" and "pelagic" ought to be modified or replaced by the following classification :-

I. Terrigenous (Murray's term, restricted)-where the deposit is formed chiefly (say, at least two-thirds, 66 per cent.) of mineral particles derived from the waste of the land.

* See, however, the deposit described on p. 18, where nearly 60 species of Polyzoa are recorded from one haul.-W. A. H. and R. A. D.

+ They seem closely comparable with the Coralline and Red Crag formations of Suffolk. 
2. Neritic* -where the deposit is largely of organic origin, its calcareous matter being derived from the shells and other hard parts of the animals and plants living on the bottom.

3. Planktonic (Murray's pelagic)-where the greater part of the deposit is formed of the remains of free-swimming animals and plants which lived in the sea above the deposit.

The last group is Murray's "pelagic" unchanged, and that, there can be no doubt, is a natural group of deposits; but " terrigenous" in the usual sense is an unnatural or heterogreneous assemblage containing some deposits, such as the gravel off Bradda Head and the sand of the Liverpool Bar, which are clearly terrigenous in their origin, along with others such as shelly sands and nullipore deposits which have much less to do with the waste of the land, but are very largely organic in origin and formed by animals and plants in situ. The proposal is then to recognise this latter group of deposits by separating them from the truly terrigenous under the name "Neritic." Probably some of the Coral sands described by Murray and Renard in their Challenger Report on Sea-Deposits would also fall into this category.

Dr. C. Kohn has kindly analysed a series of fair samples of deposits from different parts of the Irish Sea, with the following results :-

NERITIC.

TERRIGENOUS.

\begin{tabular}{|c|c|c|c|c|c|c|c|c|c|c|}
\hline & A.t & B. & C. & D. & E. & F. & G. & H. \\
\hline Silica. $\mathrm{SiO}^{2}$. & $16 \cdot 83$ & $46 \cdot 65$ & $54 \cdot 84$ & $23 \cdot 41$ & $84 \cdot 62$ & $83 \cdot 06$ & $7 \cdot \cdot 10$ & $78 \cdot 92$ \\
\hline Cal. Carbonate. CaCO & $79 \cdot 27$ & $38 \cdot 45$ & $39 \cdot 71$ & $59 \cdot 66$ & $6 \cdot 38$ & $9 \cdot 18$ & $9 \cdot 20$ & $8 \cdot 59$ \\
\hline Residue (other than Silica). & $3 \cdot 90$ & $14 \cdot 90$ & $6 \cdot 45$ & $19 \cdot 93$ & $9 \cdot 00$ & $13 \cdot 70$ & $13 \cdot 70$ & $12 \cdot 69$ \\
\hline & $100 \cdot 00$ & $100 \cdot 00$ & $100 \cdot 00$ & $100 \cdot 00$ & $100 \cdot 00$ & $100 \cdot 00$ & $100 \cdot 00$ & $100 \cdot 00$ \\
\hline
\end{tabular}

The localities and particulars are :-

A. 1 mile S.E. of Spanish Head, 16 fathoms, shell fragments.

B. I mile W. of Calf of Man, 20 fathoms, shells and spines.

C. 1 mile N.W. of Calf of Man, 18 fathoms, shell sand, spines.

D. 2 miles $W$. of Dalby, $\mathrm{x}_{5}$ fathoms, nullipores.

E. Liverpool Bar, 3 fathoms, sand.

F. Off Bahama Bank, ${ }_{3} 3$ fathoms, muddy sand.

G. King William Bank, 5 fathoms, coarse sand.

H. North end of "Hole," 20 fathoms, mud.

It will be noticed that the four terrigenous deposits (sands and muds) all show less than Io per cent. of calcium carbonate; while the four neritic have all more than $3^{8}$ per cent.-well over a third-of calcium carbonate, and one (A.) has over 79 per cent. The silica in these neritic deposits may be less than 17 per cent., and does not rise in any to 55 per cent. In round numbers it may be said that in these examples the silica makes up from 20 to 50 per

* Adopted from Haeckel's term for the zone of shallow water marine fauna, see "Plankton Studien," Jena, 1890 ; also Hickson's "Fauna of Deep Sea," 1894.

+ Shelly deposit. Contained $\mathrm{I}$ 'og per cent. of small stones not included in analysis.

¥ Contained $4^{\circ} 82$ per cent. of magnesium carbonate, in addition to calcium carbonate. 
cent., and the calcium carbonate from 40 to 80 per cent. In all the neritic deposits there are in the residue small quantities of calcium phosphate, of iron, and of alumina.

In some of these deposits the calcareous matter is formed almost entirely of Lithothamnion. Amongst the Nullipores from our neritic deposits Professor Harvey Gibson has identified the following species:- Lithothumnion polymorphum, L. calcurcum, L. agariciforme, L. fusciculutum, the variety fruticulosum, and Lithophyllum lenormandi.

One of these neritic deposits (A) has its calcareous matter formed by a large number of animals, belonging to various groups, in addition to nullipores. One sample (measuring 7 qts. $1 \frac{1}{2}$ pts., and weighing, when dry, i7 lbs. $3 t$ ozs.) which was grone over carefully for the purpose of identifying the constituent particles contains more or less fragmentary remains of at least the following 99 species, all of them forms that leave calcareous remains :-

NULLIPORES :

Lathothumnion fasciculatum

L. calcureum

Lithophyllum lenormandi

ECHINODERMaTA :

Echimus sphcert

Echinocyamus pusillus

Echinocardium cordatum.

VERMES :

Serpula, sp.

Spirorbis, sp.

POLYzoA :

\section{Cellaria fistulosa}

Cellepora avicularis

C. dichotoma

C. pumicosu

Idmonea serpens

Microporella cilintu

N. mulusii

M. violucea

Schizothecn fissa

S. divisa

Mustigophora hyndmanne

M. dutertrez

Mucronella penchii

M. variolosa

M. ventricosa

M. coccinea

Do., var. mamillata

Schizoporella auriculata

S. linearls

S. unicomis

S. simplex

S. vulgaris

S. discoiden
S. cristata

Membranipora catenularu

M. solidula

M. pilosi

M. nodulosu

M. discreta

M. auritu

M. cratecula

11. Acmingii

Hippothoa destuns

Cribrilına anmulatı

C. punctutu

C. gattyce

Crisia aculeuta

Etca recta

Amathia lendigera

Porella concinna.

Do., var. belle

$P$. minuta

Cribrilina rudiata

Phylactella collaris

P. labrosum

Micropora coriacea

Chorizopora brongniartii

Diustoporu patina

D. obelia

D. suborbicularis

Stomutopora johnstoni

S. incurvatu

Lepralia foliacea

L. pertusa

Lagenipora socialis

Simittia trispinosa

$S$. reticulatu

Lichenopora hispida 
Crustacea .

Balanus balanoides

Verrucu, sp.

Cancer pagurus

Mollusca :

Anomia ephippium

Lima elliptica

Pecten opercularis

P. pusio

Cardium edule

Venus casina

V. ovate

Nucula nucleus

Mytilus edulis

Saxicava rugosa

Tapes, sp.

Mactra solida

Pectunculus glycomeris
Acmoa testudinalis

A. virginea

Enurginula fissura

Helcion pellucidum

Trochus magus

$T$. millegranus

$T$. cinerurius

Pleurotoma, sp.

$P$., sp.

Murex erinaceus

Phasianella pullus

Natica, sp.

Buccinum undatum

Capulus hungaricus

Cypraa europea

Nassa incrassata

Rissoa, sp.

$R ., \mathrm{sp}$.

From a bag of this shelly Neritic deposit (A), described above, Mr. Andrew Scott has by careful examination managed to extract the following $3^{6}$ species of Copepoda, of which 4 are new records for our district and 8 others seem new to science :-P seudocyclops obtusatus B. \& R.; Ectinosoma sarsii, Boeck; E. melaniceps, Boeck; E. erytlirops, Brady; E. gracile, T. \& A. Scott ; Tachidius brevicornis, Müller; Stenhelia, n.sp.; Stenhelia, n. sp. ; Ameria longipes, Brady; A. longicaudata, T. Scott; A. reflexa, T. Scott ; A. gracile, n. sp.; Mesochra macintoshi, T. \& A. S.; Puramesochira dubia, T. Scott; Tetragoniceps consimilis, T. Scott ; Laophonte thoracica, Boeck; L. curticaudata, Boeck; Pseudolaophonte aculeata, n.gen. and n.sp. ; Normanella attenuata, n.sp.; Dactylopus stromii, Baird; D tenuiremis, B. \& R. ; D. Alavus, Claus; D. brevicornis, Claus ; Thalestris rufocincta, Norman; T. peltata, Boeck; Harpacticus chelifer, Müller; Zaus spinatus, Goodsir; Z. goodsivi, Brady; Idya gracilis, T. Scott ; Lichomolgus fucicolus, Brady; L. furcillatus, Thorell; Dermatomyzon nigripes (B. \& R.); Ascomyzon thompsoni, n.sp. ; Acontiophorus scutatus, B. \& R.; and two other species which have not yet been worked out.*

Mr. Thompson has also identified from a sample of the same deposit which he examined a number of the above species, and in addition the following five :Porcellidium, sp., Amcira attenuata, Laophonte spinosa, Scutellidium fasciatum, and Artotrogus orbicularis, making $4 \mathrm{I}$ species of Copepoda in all.

These $4 \mathrm{I}$ species, added to the 99 species from the same haul noted above and to the following 16 species recorded from the trawl at the time when the haul was taken, make in all ${ }_{5} 6$ species :-Mytilus modiolus, Pecten tigrinus, Trochus zizyphinus, Fissurella graca, Eulima polita, Pagurus prideauxii, Ophiothrix fragilis, Ophicoma nigra, Adamsia palliata, Sertularia abietina, Antenularia ramosa, Hydrallmania falcata, Tubularia, sp., Glycera, sp., Amphiporus pulcher, Flustra foliacea. It ought to be remembered, however, that a good many (by no means all) of the Mollusca and a few of the Polyzoa were dead.

* All the above new species have since been worked out and described by Mr. Scott, 


\section{III.-DISTRIBUTION OF FISH AND OTHER ANIMALS IN THE IRISH SEA.}

The great variety in the depths and other physical conditions described above, leads to great differences in the fauna or assemblage of animals in the various parts of the Irish Sea, and so provides suitable localities for very different kinds of fishes, and for the different stages of the fishes' life. Rocks and sea-weeds are characteristic of the Welsh and Manx coasts, sand and mud of those of Cheshire and Lancashire. The deep, cold, and relatively salt water round the Isle of Man, is very different from the less salt and sometimes much warmer waters of the shallow flats of Morecambe and Liverpool Bay. Trawling and dredging for scientific purposes has been carried on for some years now, (I) off Liverpool, Blackpool, and other points on the Lancashire Coast, and (2) off Port Erin, and neighbouring places at the Isle of Man, and the contrast in results is most marked. We have before us many records of hauls at both localities, and while Port Erin has very many species not found in Lancashire, the sandy

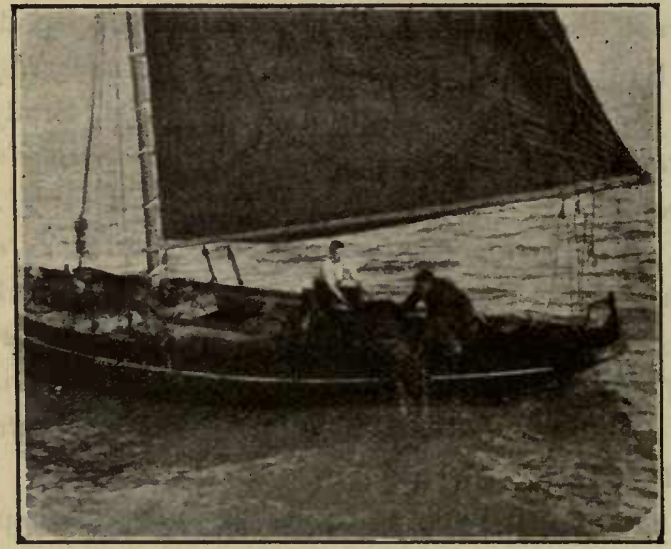

F1G. 6.-Praten boat getting the catch on board. bays of the latter show an abundance of individuals belonging to a few species which it would be difficult to match elsewhere in the district, or even possibly in Europe. Foreign naturalists who visit us and see a haul of our fish or shrimp trawl in Liverpool Bay, are generally much impressed by the profusion of specimens belonging to a small number of species-a haul numbering tens of thousands of fish alone, is frequently made ; while, when they come to Port Erin, they are equally struck by the profusion and variety of life, the relatively large number of species in one spot, as shown by a haul of the dredge or small trawl.

The following statistics of a few characteristic hauls may be of interest. They are not picked hauls, but were the first taken a few years ago (1895,) for the purpose of comparison with some statistics published from other seas. On the first of our expeditions from Port Erin, after the appearance of the summary volumes of the "Challenger" Expedition Report, in which examples of large and varied hauls are given, we counted the contents of the first haul of the small trawl. . The particulars are as follows:June 23 rd, 7 miles W. of Peel, on North Bank, bottom sand shells, depth 2 I fathoms, trawl 4 feet beam, down for 20 minutes; 232 specimens were counted, but there may well have been another I0O; they belonged to over II 2 species, and to 103 grenera. The list of these species is here given, and Marine Zoologists will see at a glance that it is nothing out of the way, but is a fairly good assemblage of not uncommon animals, such as is frequently met with when dredging in from 15 to 30 fathoms, on varied ground where a rich fauna is present, 
SPONGES :

Reniera, sp.

Halichondria, sp.

Cliona celata

Suberites domuncula.

Chalina oculata

Colenterata :

Dicoryne conferta

Halecium halecinmm

Sertularia abietina

Coppinia arcta

Hydrallmania falcata

Campanularia verticillata

Lafoëa dumosa

Antennularia ramos.

Alcyonium digitatum

Virgularia mirabilis

Sarcodictyon catenata

Sagartia, sp.

Adamsia palliata

EchiNoDermata :

Cucumaria, sp.

Thyone fusus

Asterias rubens

Solaster papposus

Stichaster roseus

Porania pulvillus

Palmipes placenta

Opliocoma nigra

Ophiothrix fragilis

Amphiura cliajii

Ophioglypha ciliatı

O. albida

Echinus sphara

Spatangus purpureus

Echinocardium cordatum

Brissopsis lyrifera

Echinocyamus pusillus

VERMES :

Nemertes neesii

Chatopterus, sp.

Spirorbis, sp.

Serpula, sp.

Sabella, sp.

Orvenia filiformis
Aphrodite aculeata

Polynoe, sp.

Crustacea :

Scalpellum vulgare

Balanus, sp.

Cyclopicera nigripes

Acontiophorus elongatus

Artotrogus magniceps

Dyspontius striatus

Zaus goodsiri

Laophonte thoracica

Stenhelia reflexa

Lichomolgus forficula

Anonyx, sp.

Galathea intermedia

Munida banffica

Crangon spinosus

Stenorhynchus rostratus

Inachus dorsettensis

Hyas coarctatus

Xantho tuberculatus

Portunus pusillus

Eupagurus bernhardus

E. prideauxii

E. cuanensis

Eurynome aspera

Ebalia tuberosa

PolyzoA :

Pedicellina cernua

Tubulipora, sp.

Crisia cornuta

Cellepora pumicosa and three or four undetermined species of Lepralids

Flustra securifrons

Scrupocellaria reptans

Cellularia fistulosa

Mollusca :

Anomia ephippium

Ostrea edulis

Pecten maximus

$P$. opercularis

$P$. tigrinus

P. pusio

Mytilus modiolus

Nucula nucleus 


\section{Cardium echinatum}

Lissocardium norvegicum

Solen pellucidus

Venus gallina

Lyonsia norvegica

Scrobicularia prismatica

Astarte sulcata

Modiolaria marmorata

Saxicava rugosa

Cyprina islandica

Chiton, sp.

Dentalium entale

Emarginula fissura

Velu ina lavigata
Turritelia terebra

Natica alderi

Fusus"antiquus

Aporrhais pes-pelicani

Oscanius membranaceus

Doris, sp.

Coryphella landsburgi

Tritonia plebeia

\section{Tunicata:}
Ascidiella virginea
Styelopsis grossularia
Eugyra glutinans
Botryllus, sp.
$B$., sp.

The following are two other similar hauls taken with different instruments (dredge and trawl), but both in less than 20 fathoms. On October 27 th, 1895 , in the steam-trawler " Rose Ann," we counted the first haul of the dredge ( 2 feet of scraping edge), and the first haul of the small trawl (4 foot beam), with the following results :-

First haul of dredge, across mouth of Port Erin Bay, from Bradda Head towards the Calf Sound, depth I 7 fathoms, bottom dead shells, 93 species in 81 genera.

\section{A scetta primordialis}

Cliona celata

Hulecium halecinum

Sertularella polyzonias

Hydrallmania falcata

Antennularia antennina

Lafoea dumosa

Obelia, sp.

Asterias rubens

Henricia sanguinolenta

Solaster papposus

Ophiothrix fragilis

Echinus sphara

Polynoe, sp.

Serpula, sp.

Pomatoceros triqueter

Spirorbis, sp.

Terebella nebulosa

Mucronella peachii

$M$. ventricosa

Smittia reticulata

Membranipora craticula

M. flemingii

M. dumerilli

M. imbellis
Microporclla malusii

M. ciliata

Lichenopora lispida

Schizoporella linearis

S. hyalina

Idmonea serpens

Scrupocellaria reptans

Tubulipora flabellaris

Crisia, sp.

Diastopora suborbicularis

D. patina

Porella concinna

Chorizopora brongniartii

Cellepora costazii

Bulanus balunoides

Chthamalus stellatus

Cyclopina gracilis

Misophria pallida

Thalestris clausii

Ectinosoma spinipes

Cyclopicera lata

C. nigripes

Lichomolgus maximus

Dermatomyzon gibberum

Artotrogus magniceps 
Zaus goodsiri

Iphimedia obesa

Melitu obtusatu

Lilljeborgia kinathani

Aora gracilis

Erichthonius abditis

Phtisica marina

Gnathia (Anceus), sp.

Hyas araneus

$H$. coarctatus

Hippolyte varians

Spirontocaris spinus

Eupagurus bernhardus

Galathea intermedia

Ebalia tuberosa

Portunus, sp.

Achelia echinata

Anomia ephippium

Nucula nucleus

Mytilus modiolus

Pecte'n opercularis

P. maximus
P. pusio

Saxicava rugosa

Venus lincta

Tapes, sp.

Cyprina islandica

Chiton, sp.

Emarginula fissura

Velutina lavigatu

Capulus hungaricus

Buccinum undatum

Fusus antiquus

Trochus cinerarius

Eolis viridis

Polycera quadrilineatu

Perophora listeri

Ciona intestinalis

Ascidiella virginea

Ascidia mentula

A. scabra

Styelopsis grossulariu

Cynthia morus

The first haul of the small trawl, on the same occasion, off the Halfway Rock, in 18 fathoms, yielded II species in 93 genera, as follows:-

Leucosolenia coriacea

Suberites domuncula

Cliona celatu

Coppinia ureta

Sertularia abietina

Antennularia ramosa

Plumularia, sp.

Sagartia nivea

Sarcodictyon catenata

Palmipes membranacens

Soluster endeca

Asterias rubens

Henricia sanguinolenta

Porania pulvillus

Echinus sphoera

Echinocyumus pusillus

Lincus marinus

Amphiporus pulcher

Micrura fasciolatu

Filograna implexa

Serpula, sp.
Pomatoceros triqueter

Polynoe, sp.

Etea recta

Scrupocellaria scrupea

$S$. reptans

Idmonea serpens

Schizotheca fissa

Crisia ramulosa

C. cornuta

Cellepora pumicosa

C. dichotoma

Alcyonidium gelatinosum

A. mytili

Cellaria fistulosa

Membranipora pilosa

$M$. craticula

M. Acmingï

M. imbellis

Porella concinna

Chorizopora brongniurtii

Smittia trispinosa 
S. reticulata

Schisoporella linearis

Mucronella peachii

M. ventricosa

M. coccinea

Diastopora obelia

Microporella malusii

Hippothoa divaricata

$H$. distans

Stomatopora johnstoni

Bulanus balunoides

Thalestris peltutu

Ductylopus fluvus

Laophonte spinosa (?)

Ectinosoma atlanticum

Cyclopicera gracilicauda

Lichomolgus liber

Dyspontius striatus

Acontiophorus scutatus

Artotrogus orbicularis

Stenothoc marina

Leucothoe spinicurpu

Amphilochus manudens

Cyproidea brevirostris

Tritceta gibbosa

Cressa dubia

Podocerus cumbrensis

Spirontocaris spinus

Stenorhynchus, sp.

Portumus, sp.

Eupugurus bernhardus

E. cuunensis

Galathen intermediu.

G. dispersu

Pandalus annulicornis
Crangon allmani

Xuntho tuberculatus

Pycnogonum littorale.

Anomiu ephippium

Ostrea edulis

Mytilus modiolus

Pecten maximus

P. tigrinus

P. pusio

P. opercularis

Astarte, sp.

Venus casina

Tapes, sp.

Nucula nucleus

Saxicava rugosa

Pectunculus glycimeris

Chiton, sp.

Cyprina islandica

Tectura virginea

Emarginula fissura

Pleurotoma, sp.

Trochus millegramus

T. zizyphinus

Goniodoris nodosa

Amaroucium, sp.

Didemnum, sp.

Leptoclinum maculatum

Botryllus, sp.

Ascidiella virginea

Ascidia mentula

A. plebcia

Corella parallelogranma

Styclopsis grossularia

Cynthia morus

A third haul, on this same occasion (October 27 th) grave us, from 16 fathoms, ${ }^{6} 6$ species (see above, p. 19).

In order to get another case, on entirely different ground, not of our own choosing, on the first occasion after we commenced counting these hauls, when we were out witnessing the trawling observations of the Lancashire Sea-Fisheries steamer "John Fell," we counted, with the help of Mr. Andrew Scott and the men on board, the results of the first haul of the shrimp trawl. It was taken on July 23 rd at the mouth of the Mersey estuary, inside the Liverpool Bar, on very unfavourable ground: bottom muddy sand, depth 6 fathoms. The shrimp trawl ( $1 \frac{1}{2}$-inch mesh) was down for $\mathrm{r}$ hour, and it brought up over seventeen thousand specimens referable to the following thirty-nine species, belonging to thirty-four genera :- 
Solea vnlgaris

Pleuronectes platessa

$P$. limanda

Gadus callarias

G. aglefinus

G. merlangus

Clupea sprattus

C. harengus

Trachinus vipera

Agonus catuphractus

Gobius minutus

Raia clavata

R. maculata

Mytilus edulis

Tellina tenuis

Mactra stultorum

Fusus antiquns

Curcinus manas

Portunus, sp.

Pagurus bernhardus
Crangon vulgares

Sacculina, sp.

Amphipoda (undetermined)

Longipedia coronata

Ectinosoma spinipes

Sunaristes paguri

Dactylopus rostratus

Cletodes limicolu

Caligus, sp.

Flustra foliacea

Aphrodite aculenta

Pectinaria belgica

Nereis, sp.

Asterias rubens

Hydractinia echinata

Sertularia abietina

Hydrallmania falcata

Aurelia murita

Cyancea, sp.

These numbers have been exceeded on many other hauls in the ordinary course of work by the Fisheries steamer in Liverpool Bay. For example, on this occasion the fish numbered 5,943, and we have records of hauls in which the fish numbered over 20,000. The shrimps sometimes probably number as many again, and if the starfishes and other abundant invertebrates are added, the total must sometimes reach such enormous numbers as from 45,000 to 50,000 specimens in a single haul of the trawl in shallow water, not including microscopic forms. Hauls such as this are doubtless as prolific of individuals as any of those hauls sometimes quoted containing large numbers of specimens (of a very few species) of Copepoda and Schizopoda from waters deeper than 50 fathoms, and are certainly far more prolific in species and genera; while hauls such as the three quoted above under dates June $23^{\text {rd }}$ and October 27 th compare favourably as to variety of life, i.e., as to number of species and genera, with the deep water hauls of the "Challenger" expedition made with a far larger trawl.

On the next occasion, when on board the "John Fell," on August 3rd, I895, two members of the party (A. O. Walker and W. A. Herdman), identified the species brought up in the first haul of the trawl ( 5 -inch mesh), taken in Red Wharf Bay, Anglesey, at a depth of 4 to 7 fathoms. They were 78 species, belonging to 67 genera, as follows :-

Solea vulgaris

\section{S. Intea}

Pleuronectes platessa

$P$. limanda

P. flesus

Gadus callarias

G. aglefinus

G. merlangus
Callionymus lyra

Raia maculata

Fusus antiquus

Buccinum undatum

Natica alderi

Pleurotoma, sp.

Philine, sp.

Eolis, sp. 
Polycera quadrilineata

Corbula gibba

Mactra stultorum

Scrobicularia alba

Portunus depurator

Corystes cassivelaunins

Hyas coarctatus

Stcnorhynchus phalangium

Eupagurus bernhardus

Crangon vulgaris

Pscudocuma cercaria

Diastylis rathkei

D. spinosa

Balanus balanoides

Paratylus szeammerdammii

Harpinia neglectu

Ampelisca lavigata

Monoculodes longimamus

Amphilochus melanops

Parinmbus typicus

Achelia echinata

Aphrodite aculeata

Nereis, sp.

Terebella, sp.

(?) Syllis, sp.

Serpula, sp.

Spirorbis, sp.

Cellaria fistulosu

Flustra foliacea

Eucratea chelata

Scrupocellaria reptans
Bugula, sp.

Cellepora punicosa

C. avicularis

Porella compressa

Mucronella peachii

Mcmbranipora membranacea

M. pilosa

Alcyonidium gelatinosum

Vesicularia spinosa

Gemmellaria loricata

Lichenopora hispida

Crisin eburnea

C. cornuta

Idmonea serpens

Asterias rubens

Amphiura squamata

Ophioglypha albida

Tealia crassicornis

Alcyonium digitatum

Clytia johnstoni

Lafoëa dumosa

Hydrallmania falcata

Hulecium halecinum

Antennilariu ramosa

Coppinia arcta

Sertularella polyzonias

Sertularia abietina

$S$. argentea

Diphasia rosacea

D. tamarisca

Tubularia indivisa

This was a haul-from very shallow water - which combined mere quantity of life, i.e., number of individuals, with variety of life or number of species and genera. The ten species of fish were represented by 879 individuals, and we estimated that there were some hundreds of crabs and of starfishes, and some thousands of shrimps. The numbers of the Molluscs, of the hermit-crabs, of Balanus and of Spirorbis were also very large.

From these statements it is clear that whether it be a question of mere mass of life or of variety of life, haul for haul, the shallow waters can hold their own against the deep sea, and form in all probability the most prolific zone of life on this globe. And of this zone, as seen in the Irish Sea, two very distinct types of abundance are seen, the Manx waters abounding in species, and the Lancashire in individuals.

Now all these animals, large or small, bottom-haunting or free-swimming, if not themselves fish, and edible, are related, directly or indirectly, as food or enemies, or competitors in the struggle for existence, with the subjects of our commercial fisheries. The various fishes move or migrate about the Irish Sea according to the seasons, the temperature, and the 
distribution of food. One locality serves as spawning grounds, another as the " nurseries," in which the young fish congregate in enormous numbers, and still other localities serve as feeding grounds at different times of the year. If we omit the more active migratory fish (such as the Herring), many of the others, of more sedentary habits (such as the flat fishes), probably never leave the Irish Sea throughout their lives. Their spawning grounds are in the deep water round the Isle of Man, their "nurseries" on the Lancashire coast, and their feeding grounds"elsewhere over the area according to the season and the age of the fish.

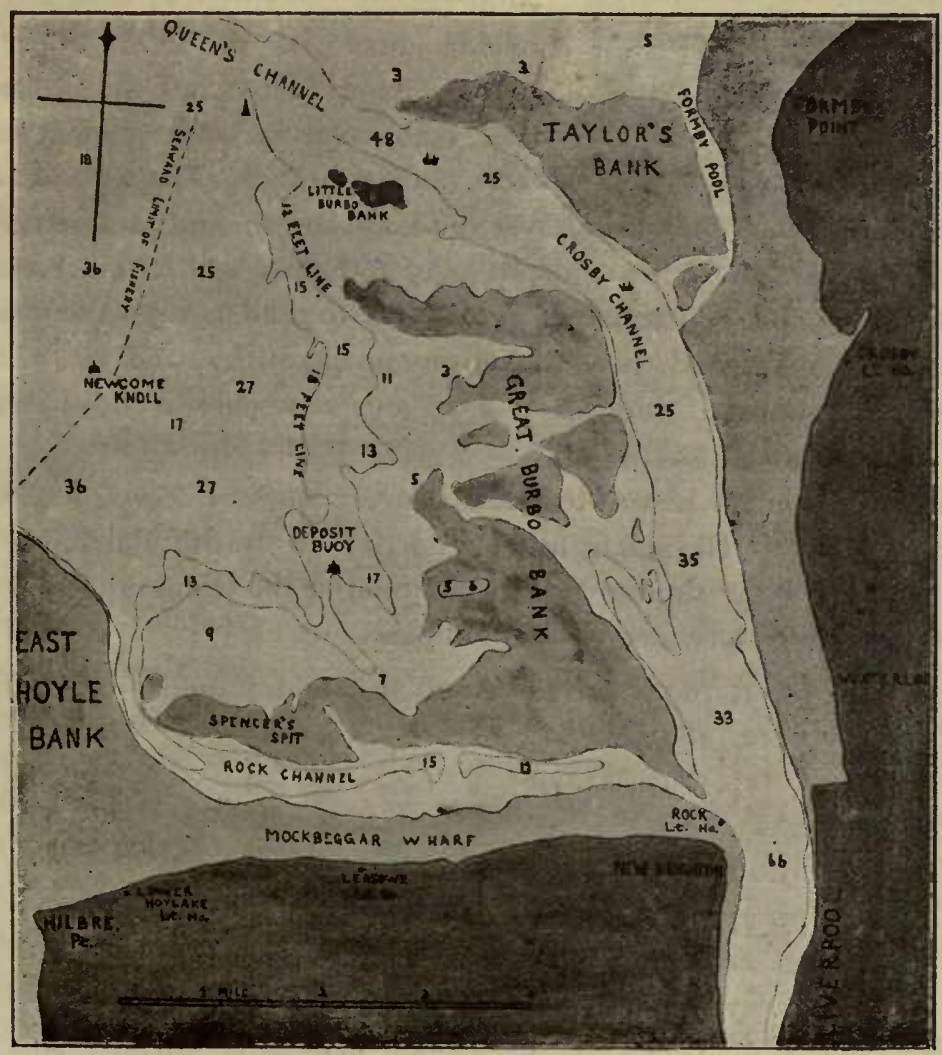

FIG. 7.-Mersey Slurimping Grounds.*

The banks and channels off the mouth of the Mersey (see Fig. 7), and the similar areas along the coast by Southport and Blackpool, from the Dee to Morecambe Bay, form one of the most remarkable flat-fish nurseries in the world. It is also, however, a famous shrimping ground, and, without at the moment going into the question of how far the one fishing industry is interfering with the prosperity of the other, there can be no doubt of the fact that the operations of the shrimpers at present result in an enormous destruction of young fish. It is a common experience on these grounds at certain times of year to catch thousands of very small fish at each haul, in the proportion of about a thousand young fish for each quart of shrimps taken.

*From the article by Johnstone and Jenkins in our last "Sea-Fisheries Laboratory Report, 190I." 
Here are a few hauls which show this remarkable state of affairs :Sept. 25th, 1893, off Blackpool, 14,892 small fish and 3 quarts of Shrimps.

Dec. 28th, 1893 ,

Nov. 211, I 894 ,

$\begin{array}{lrr}, & 20,889 & , \\ , & 10,810 & , \\ , & 12,695 & , \\ , & 19,800 & , \\ , " & 18,536 & , \\ , & 13,161 & , \\ , & 5,378 & , \\ ,, & 2,430 & ,\end{array}$

$\begin{array}{lcll}, & 22 \frac{1}{2} & , & , \\ , & 1 \frac{1}{4} & , & , \\ , & 3 & , & , \\ , & 10 & , & , \\ , & 18 & , & , " \\ , & 13 & , & , \\ , & 4 \frac{1}{2} & , & , \\ , & \text { only a } & \text { a few } & \text { shrimps }\end{array}$

Oct. 3 Ist, 1895 ,

Dec. I 8 th, 1895 ,

Jan. 21 st, 1896 ,

Feb. 6th, 1901,

Mar. 19th, 1901,

(n)

These hauls were taken with the shrimp trawl, and the haul lasted in each case from 40 to 60 minutes. The fish were all edible species of the most important kinds, comprising soles, plaice, dabs, cod, haddock, and whiting. The ground off Blackpool is an area of the territorial water measuring over 3 miles in length, and containing about i I square miles, extending from the shore to a depth of 5 fathoms, which has been closed against trawling for the last so years. The hauls quoted above, and many others in our statistics, show that young fish congregate there in enormous quantities, and there can be no cloubt of the value to the neighbouring fishing grounds of this sanctuary as the habitat of a reserve stock of young fish.

Similar hauls made in the rest of the Lancashire "nursery" grounds, where shrimping takes place freely, such as Heysham to the north and Burbo Bank, off the Mersey (see Fig. 7), to the south, show similar results, although the total numbers of young fish taken are not so great. Here are a few samples:-

Heysham, August 4, 1892, I, I 44 small fish and 7 quarts of shrimps.

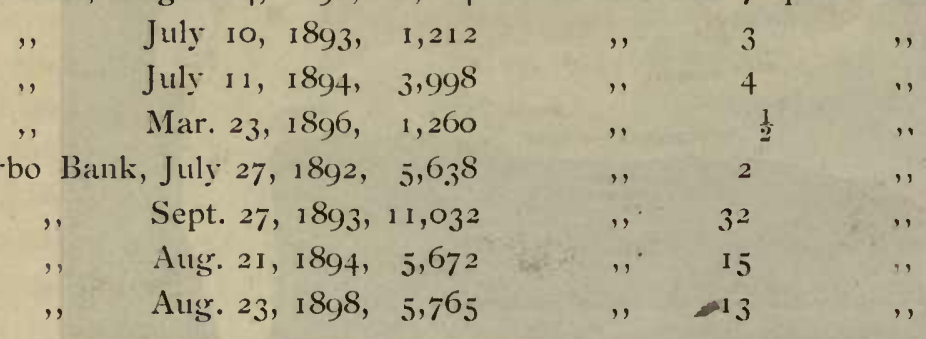

In the last quoted haul 562 of the young fish were soles. We have reason to think that the number of young soles on the Blackpool closed ground has kept steadily increasing of late years.

Our experimental hauls have shown us over and over again that the shank net is much less destructive to young fish than the shrimp trawl, while catching quite as many shrimps. In comparative hauls that were made on the Blackpool ground on December 28 , 1893, the shrimp trawl took $22 \frac{1}{2}$ quarts of shrimps and 20,889 undersized fish, while two shank nets took $2 \mathrm{I} \frac{1}{2}$ quarts of shrimps and 8,929 fish, thus saving 11,960 young fish with a loss of only one quart of shrimps. Mr. Dawson has devised a modification of the shank frame, which consists in having the bottom of the net attached to a bar set about three inches above the ground, the result being that as the shrimps spring upwards when disturbed they clear the bar and so enter the net, while the fish, which remain at a lower level, escape underneath. In the experiments which have been made on the Lancashire coast, this bar shank net gives good results, but it has not been adopted commercially. 
The question has often been raised as to how far the young fishes brought up in the shrimp traivl, if not actually dead, are so seriously injured, that they would not recover, even if promptly returned to the sea. We have made many experiments, and kept many records bearing upon this matter. In 1893 , we devised a series of "vitality" experiments, which were carried out on the Fisheries' steamer "John Fell," for several years. Sample fish from the various hauls, were placed, after their condition had been recorded, in a large tub, through which there flowed a constant circulation of sea water. The condition of the fish at stated intervals, half-an-hour and then hourly, was noted, and the ultimate recovery

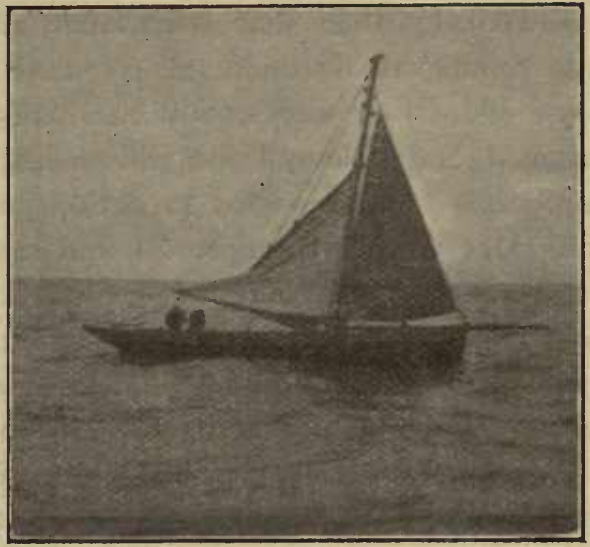

F1G. 8.-Boat working a Shrimp Trawel. or death. The result, naturally, depended greatly upon the kind of haul, the length of the drag, the weight of the catch, the muddiness, and other particulars; but it was also found that some fish are much more delicate than others, and can stand less knocking about and pressure. Flat fish on the whole can stand more than round fish. Soles seemed to be specially hardy, about 95 per cent. surviving; while Plaice came next, 8I per cent. of those caught, some with the fish and others with the shrimp trawl, having recovered after being in the tub on the average for about an hour. It is obvious, then, that under ordinary circumstances the majority of such fish caught might still live if returned promptly to the sea. But even if one puts the most favourable interpretation upon such experiments, it is obvious that there is an immense amount of destruction going on in the Lancashire fish "nurseries."

These extensive "nurseries" are an important link in the life-cycle of the more sedentary fish of the Irish Sea. They depend upon the off-shore spawning grounds for their supply, and in their turn they give recruits to the stock of adolescents and adults on the fishing grounds.

Taking the Plaice as a typical sedentary flat-fish, and the one to which attention has been largely directed in our district, ${ }^{*}$ we find that the females become mature in our seas at a size of from 13 to $I_{5}$ inches, and the males at about I inches; they are probably at that time about 3 or 4 years old. The spawning of the plaice takes place from February to the end of May and the female fish lays from 300,000 to 400,000 ova. The egg is of relatively large size, as edible fish-eggs go, being from $1.6 \mathrm{~mm}$. to nearly $2 \mathrm{~mm}$. in diameter. The spawning takes place in deep water, say 20 to 30 fathoms, at a distance from land, and the egg floats at or near the surface of the sea during its development. At a temperature of $10^{\circ} \mathrm{C}$, the embryonic development, from the fertilisation of the egg till the larva is hatched, takes about 12 days; and then there emerges from the eggcovering a little plaice larva of about $6.5 \mathrm{~mm}$. in length. At first the larva does not eat, and subsists upon the remains of the nourishing matter that was in the egg; but this yolk sac only lasts for about a week, and shortly before it has disappeared the larva begins to feed, at first upon Diatoms and minute larval Molluscs. A fortnight later, three weeks from hatching, it measures about $7.5 \mathrm{~mm}$, and now feeds

* See the Memoir on the Plaice by F. J. Cole and J. Johnstone, appended to the Lancashire Fisheries Laboratory Report for Igoı. 
upon larval Crustacea. Up to the age of about a month, the little fish is perfectly symmetrical; then that remarkable rotation of the head sets in, which results in both eyes coming to lie upon the coloured side of the animal. The complete metamorphosis takes about two weeks, and the little animal is then $13 \mathrm{~mm}$. in length. The fish, now flattened and coloured like the adult, rests upon the left side, and feeds chiefly upon Copepoda. A somewhat rare Copepod, called Fonesiella hyana, which was not known until Mr. I. C. Thompson found and described it from our district, is apparently a favourite food of young plaice at this period, since we frequently find it in their stomachs. When a size larger again, say from $3 \mathrm{~cm}$. to 7 or $8 \mathrm{~cm}$, the animal feeds upon small worms and upon the feebler Crustacea, such as Mysis. Later on again, and during the remainder of its life, the plaice feeds mainly on Lamellibranch Mollusca, such as Mactra and Donax. From the time of its metamorphosis onwards the plaice is a bottom-living fish, feeding on the ground, in which it frequently lies partially buried. It has small powers of migration, and in such a district as the Irish Sea is all its life exposed to man and liable to be captured. In its early youth it is harried by the shrimpers of all kinds along the shores, and in the estuaries, when it gets a little larger but is still immature, it is the object of an extensive fishery on the coast by means of stake nets, and on the in-shore grounds by trawlers; finally, in the open sea, it is one of the chief sources of revenue to the deep-sea trawler. In this constant liability to be captured, it contrasts markedly with migratory fish, such as the herring and mackerel, and even with fish such as the cod, which at times pass beyond our local fishing operations. Hence the danger of over-fishing leading to a serious decrease of such an important food-fish as the plaice in British waters.

Our Lancashire statistics, taken over the last Io years, although in many respects not so continuous and complete as we should desire, give us many valuable items of information in regard to the distribution and abundance of young and old fishes at different seasons. The following extracts as to the plaice are of interest. They are all from hauls with the shrimp trawl :-

$$
\begin{aligned}
& \text { June } 2 \text { Ist, } 1893 \quad \ldots \quad \ldots \quad \text { Heysham } \quad \ldots \quad \ldots \quad \text { 5 } 1 \text { io plaice, about } 1 \frac{1}{2} \text { inches long. } \\
& \text { August } \mathrm{I} \text { ith, } 1892 \quad \ldots \quad \quad, \quad \ldots \quad \ldots 1,200 \quad, \quad \ldots \quad, \quad 2 \quad 2 \quad,
\end{aligned}
$$

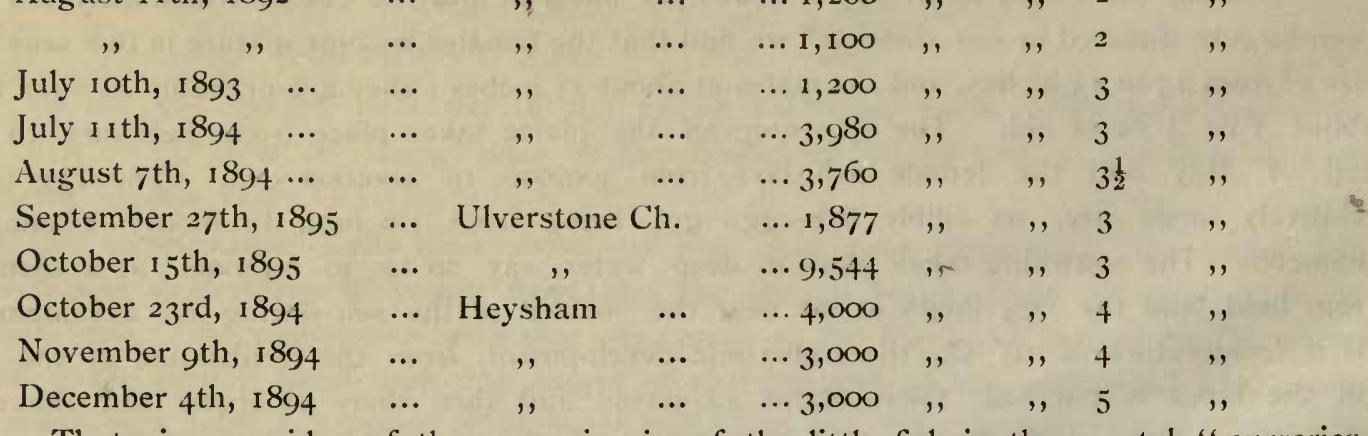

That gives an idea of the range in size of the little fish in the coastal "nurseries," where the minute plaice, which has just completed its metamorphosis, usually appears in May, and from which it gradually moves out into deeper water about the end of autumn. These times are, of course, liable to some variation, from year to year, according to the season and state of the weather. Then larger, but still immature fish, say from 5 to I 1 or 12 inches in length, are found a little further out along the banks, such as just outside the Blackpool ground, and outside the Liverpool Bar, in depths of about to fathoms. Larger mature 
specimens are also frequently found in the inshore grounds in quantity in autumn, as, for example, in the sandy bays and in the channels between the banks, where they come to feed; but the first severe frost in winter drives them away. They either burrow more deeply in the sand, or move off shore altogether to deeper water. These large fish are then "filling up" with spawn, and at the end of the year, and in January, are found congregating on the spawning banks far out from land. Our chief areas in the Irish Sea where the plaice spawns are midway between Lancashire and the Isle of Man, and to the south and west of the Isle of Man, at depths of from 20 to 30 or 40 fathoms. It is on these and other off-shore grounds that the chief fishery for large plaice by the deep-sea trawlers takes place.

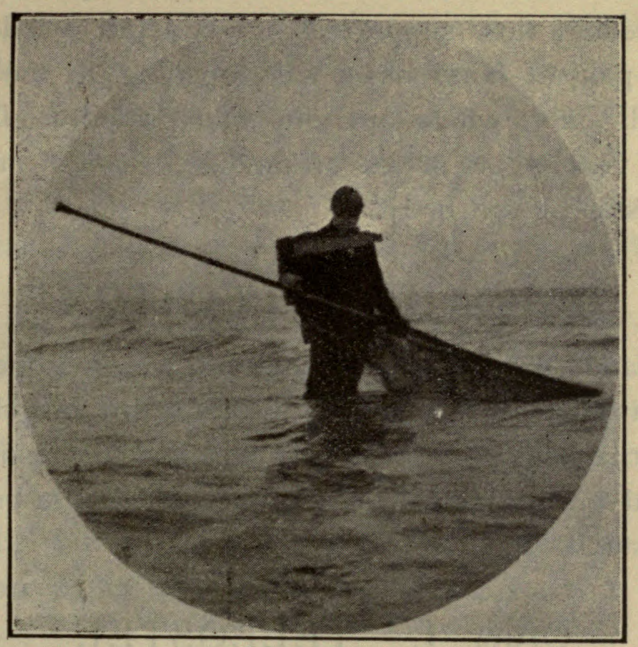

FiG. 90-Shrimping wath a "Push-net." 


\section{IV.-THE FISHES OF THE IRISH SEA.}

\section{In this section the fishes are arranged systematically in Zoological Classifi- cation,* beginning with what are usually regarded as the highest or most specialized forms.}

\section{Class PISCES.}

Vertebrate aquatic animals with an anterior and a posterior pair of limbs in the form of fins; having median fins supported by skeletal or dermal fin-rays; provided with jaws, and having a pair of blind nasal sacs opening to the exterior but not into the mouth; breathing by gills only, which open by one or more gill clefts near the front of the body; heart entirely venous; a series of modified scales and sensory organs form a "lateral line" along the side of the body.

\section{Division I. TELEOSTOM I}

Branchial arches and gills covered by one large opercular fold; gills free upon the gill arches, not enclosed in pouches. Skeleton largely or wholly bony, with both membrane and cartilage bones. Mouth terminal or nearly so. The pelvic fins usually placed far forward on the body. The roof of the fore-brain is not nervous. The ova are numerous and small.

\section{Order I. TELEOSTEI.}

Skeleton bony, vertebræ solid. Heart with a bulbus, and no conus arteriosus; no intestinal spiral valve. Tail homocercal. Optic nerves simply cross. There are seven branchiostegal rays supporting a part of the gill cover.

This includes our ordinary bony fishes, as distinct from the sturgeons (Chondrostei), and the cartilaginous fishes (Elasmobranchii), such as skates and sharks.

\section{Section PHYSOCLYSTI.}

Air-bladder, when present, without a duct in the adult animal. Gills pectinate.

This includes the great bulk of our ordinary bony fishes, as distinct from the Herring tribe and the Salmonidæ.

\section{A. ACANTHOPTERI.}

The dorsal fin is protected by some unjointed spines. The position of the pelvic fins is variable. The inferior pharyngeal bones are paired.

This includes a very large number of our common shore fishes, most of which are not marketable. They are distinguished by their stiff spiny fins from the important foodfish of the Cod and flat-fish tribes (Anacanthini) which follow.

\footnotetext{
* The classification given here takes no account of fossil forms, nor of groups unrepresented in our seas.
} 


\section{Family PERcide.}

LABRAX LUPUS (Lac.) - The Bass.

(Day's British Fishes, vol. I., p. 8, Pl. II.)

(Fish. Mus., Zool. Dep., Univ. Coll., Liverpool.) Local Name, "Sea-Perch."

This active fish ranges from Norway to the Mediterranean, and is usually found in shoals. In Britain it is commonest on the southern coasts. In our district it has been recorded from "the Dee and round the neighbouring coast" (Byerley), off Formby, and othed places along the Lancashire coast. It is common at times along the coast of North Wales, and in the Menai Straits, where it is known as "Sea-perch," and it is also taken in the Barrow Channel in summer on long lines baited with Tealia.

The Bass appears to spend the winter in the deep sea, and comes to the coast in summer, generally May, June, and July. In our district the Bass appears about July, and is almost entirely taken by lines, except occasionally and accidentally in salmon nets, weirs, and even in trawls, in shallow water.

Bass are sometimes taken in large quantities in Barrow Channel with draft nets, in Morecambe Bay, and also in the Menai Straits, at Holyhead, and elsewhere round the coast of Anglesey. They disappear about September, and go off again to the deep water.

\section{Serranus cabrilla (Linn.) - The Gaper.}

(Day's British Fishes, vol. I., p. I4, Pl. IV.)

This species ranges from the south and west of England to the Mediterranean. It is also found at Madeira and round the Cape of Good Hope.

It is recorded by Eyton* "several taken by lines in a small rocky bay between Rhoscolyn and Holyhead," but our district must be about the extreme northern limit of its clistribution. It breeds in the end of summer.

\section{Family Mullide.}

Mullus barbatus, var. surmuletes, Linn.-Red Mullet.

(Day's British Fishes, vol. I., p. 22, P1. VIII., Fig. 2.)

This variety, the only mullet recorded from our waters, is the "surmullet," or striped red mullet. It ranges from Scandinavian seas to the Mediterranean, and is also found at the Canary Islands. In British seas it is most abundant on the south and west. The only records in our district are from Eyton, who says he once saw an enormous shoal of this fish in the harbour at Holyhead, numbers of which were taken in the nets; and from Prof. White, of Bangor, who tells us that he has two small ones, taken in the Menai Straits, in August. We cannot hear of any others cases of red mullet having been taken in our neighbourhood in recent years.

\section{Family SPARIDE.}

\section{Cantharus lineatus (Montagu)-Black Sea-Bream.}

(Day's British Fishes, vol. I., p. 26, Pl. IX.)

The black sea-bream, or "old wife," extends from the south of Norway to the Mediterranean, and is also found at the Canary Islands. In British seas it is apparently confined to the south and west, and is fairly common along the west coast of England. 


\section{Sparus centrodontus, De la Roche-Common Sea-Bream.}

(Day's British Fishes, vol. I., p. 36, PI. XIII.)

(Fish. Mus., Zool. Dept., Univ. Coll., Liverpool.) Local Name, "Sea-Bream."

This fish ranges from Scandinavian seas to the Mediterranean, through both the North Sea and the North Atlantic. On the British coasts it is especially abundant on the south and west. It may be caught in our district in the trawl, and is sometimes brought into the Liverpool market. "Common near Holyhead" (Eyton); taken in the Barrow Channel near Piel, occasionally in Menai straits (White), and abundant in summer outside Port Erin Bay, where it is caught by lines. Frequently taken in and near Morecambe Bay, and on the fishing grounds between Lancashire and the Isle of Man.

\section{Family SCORPENIDE.}

\section{Sebastes norvegicus (Ascan.)-Norway Haddock.}

(Day's British Fishes, vol. I, p. 42, Pl. XVIII.)

This is a northern fish, ranging from Greenland and Spitzbergen, down to the British seas, and as far as New York on the other side of the Atlantic. Byerley recorded a specimen as taken in our district in $185_{1}$, and there is one in the Liverpool Public Museum, recorded as having been taken in 1871 , from 20 miles north west of the Bell buoy (now the Mersey Bar Light Ship.)

\section{Family CotTide.}

\section{Cottus scorpius, Linn.-Short-spined Cottus.}

(Day's British Fishes, vol. I. p. 49, Pl. XIX.)

(Fish. Mus., Zool. Dep., Univ. Coll., Liverpool.) Local name, "Bull-head."

This fish is variously called the sea-scorpion, the father-lasher, the short-spined cottus and the sting-fish, but that latter designation is much better kept for the true sting-fishes belonging to the genus Trachinus. It is a northern form, extending from the Arctic regions down to British seas, and, like some other northern species, attains to a very much larger size in the colder waters. On the coast of Greenland it is said to reach a length of 6 feet, while in our seas the usual size is about as many inches. It is found in the North Sea and the Baltic and all around the British Isles. In our district it is taken commonly in shrimp trawls in shallow water, and is sometimes found in shore-pools, where it lays its eggs in spring. It is common at Port Erin and elsewhere in the Isle of Man; also about Piel in the Barrow Channel, and in the Menai Straits and round Anglesey.

\section{Cottus bubalis, Euphr.-Long-spined Cottus.}

(Day's British Fishes, vol. I., p. 51, Pl. XX.)

(Fish. Mus., Zool. Dep., Univ. Coll., Liverpool.) Locul name, "Bull-head."

This fish, like the last, is also sometimes known locally as the "father-lasher." It ranges in distribution from the Arctic regions to the coasts of Spain, and is found all round the British coasts; In our district it is caught occasionally in the Dee (A. O, 
Walker), Menai Straits (White), and on the North Coast of Wirral (Byerley); "taken also near Piel in Barrow Channel; and common at Port Erin. It lays its eggs in winter.

\section{Trigla tucerna, Linn.--Yellow Gurnard.}

(See T. hirundo, Day's British Fishes, vol. I. p. 59, Pl. XXIV.)

(Fish. Mus., Zool. Dep., Univ. Coll., Liverpool.) Local names, "Tubs" and "Gurnets."

This species ranges from Norway to the Mediterranean, and occurs all round the British Islands, especially on the off-shore grounds.

This yellow or "sapphirine" gurnard is known locally as "Tubs." It is said to be "very common" by Byerley (1854), but is really much the rarest of the 3 species of gurnard found in our district. It is only occasionally found in any numbers in the trawl on the off-shore grounds, or more rarely on lines, and for the most part in summer. We have taken it in the Barrow Channel, near Piel. It breeds during the spring and early summer (January to June), and Mr. A. O. Walker, when trawling in the Dee for shrimps in March, has taken the young. He records them as common in 1857 . They are also found in other places in our in-shore waters, e.g., near the Deposit buoy at the mouth of the Mersey. Small specimens of this species are of a greyish colour, and the pectoral fins are marked with blue spots, while the older fish are of a light yellow colour.

\section{Triglat PINI, Bloch.--Red Gurnard.}

(See $T$. cuculus, Day's British Fishes, vol. I., p. 58 , Pl. XXIII.)

The Red Gurnard, known locally here as "Soldiers," is usually taken in the trawl and occasionally on lines, but there is no special fishery for it. It is not so abundant as the grey, but not so scarce as the yellow in Lancashire waters. It is taken mostly on rough ground in spring and sumner, especially May to July. Byerley (1854) speaks of it as the least frequent of our three species of gurnard, but that is certainly not the case now. It is sometimes in quantity on the off-shore grounds, is taken in the Menai Straits, and is fairly common at Port Erin and the neighbourhood.

The distribution is in the main like that of the last species, from Scandinavian seas to the Mediterranean.

\section{Trigla gurnardus, Limn.-Grey Gurnard.}

(Day's British Fishes, vol. 1., p. 62, Pl. XXV.)

(Fish. Mus., Zool. Dep., Univ. Coll., Liverpool.) Local Name, "Knowds" or "Gurnets."

The distribution is practically the same as that of the two previous species, i.e., from Norway to the Mediterranean.

The Grey Gurnard (locally "Knowds") is taken by the trawl, sometimes in large numbers, especially in the latter part of the year, and in the deeper waters. This is an abundant British species, and is our commonest gurnard in the Irish Sea. It may be taken all over our district. We have had it from the Barrow Channel and Menai Straits, and it is very common in the neighbourhood of Port Erin, and also off Maughold Head, Isle of Man. 


\section{Family Cataphracti. Agones cataphractus (Linn.) - Pogge. \\ (See Day's British Fishes, vol. I., p. 67, P1. XXVIll., Fig. 1.)}

(Fish. Mus., Zool. Dep., Univ. Coll., Liverpool). Local Name, "Toad-fish."

This little fish, the Pogge (or armed Bull-head), is very common in shallow water, and is constantly brought up in the shrimp trawl; it is especially abundant at the mouths of our estuaries. A. O. Walker finds it very common in the Dee estuary, and it is also abundant off Liverpool, in the Barrow Channel, Menai Straits, and elsewhere.

It ranges from the coasts of Iceland and Norway through the Baltic and North Sea to the British Islands.

\section{Family Pediculati.}

Lophius piscatorius (Linn.)-Angler.

(Day's British Fishes, vol. I., p. 73, Pl. XXIX.)

(Fish. Mus., Zool. Dep., Univ. Coll., Liverpool). Local Name, "Devil-fish."

This fish, also known as the Fishing Frog or Devil-fish, is fairly common all round the British coast, and sometimes attains a large size (6 feet). It is commonest in the south, and is frequently taken stranded on the beach, or in weirs and other nets in the Dee, the Mersey, the Barrow Channel, the Menai Straits, and other parts of our area; it is occasionally taken on long lines in the neighbourhood of the Calf, Port Erin. Although not marketable, when caught in the trawl the tail-part is frequently cut off, sold and eaten. It is sometimes caught in Rhos Weir, near Colwyn Bay, and Mr. Siddall, Chester, tells us that in June, 1901, he found one there $4 \mathrm{ft}$. 6ins. long and $2 \mathrm{ft}$. wide, which had a round brass tray of 12 inches diameter fixed in the back of its mouth, and fitted so tightly that it could not be removed. It ranges from the Baltic to the Mediterranean, and is also recorded from Newfoundland to the Cape of Good Hope.

\section{Family Trachinidas.}

Trachinus vipera, Cuv. \& Val.--Lesser Weever.

(Day's British Fishes, vol. 1., p. 81, Pl. XXXI.)

(Fish. Mus., Zool. Dep., Univ. Coll., Liverpool.) Local name.-."Sting-fish."

This fish, also known as the Viper Weever or the "Sting-fish," is the smaller of the two British species of Trachims, but is much the more abundant in our district, and is also more venomous than $T$. draco. It was shown by Byerley (Proc. Lit. \& Phil. Society, Liverpool, vol. I. p. I56) that both the double-grooved opercular spine and also the spines of the first dorsal fin are poison organs.

Taken in large numbers while shrimping, and are eaten locally; but do not seem to be sold anywhere in our district. It is said that the head and dorsal fin are cut off, and the fish is then fried. The presence of these poisonous fishes amongst the shrimps is one of the reasons why shrimping is not carried on during the night, as it would be dangerous to attempt sorting out the catch in the dark.

We find it up to 7 inches in length at the mouth of the Mersey. It ranges from the North Sea to the Mediterranean, and is common all round the English coast. We have taken it 
off Liverpool, in the Barrow Channel, the Dee estuary, and the Menai Straits, and it is abundant along the outlying banks.

\section{Trachinus draco, Linn.-Greater Weever.}

(Day's British Fishes, vol. I., p. 79, Pl. XXX.)

(Fish. Mus., Zool. Dep., Univ. Coll., Liverpool.)

This species is certainly much rarer than the last with us. Eyton says "occasionally found on the Welsh Coast"; Byerley records it somewhat doubtfully. We trawled two specimens from the "John Fell," off the Welsh Coast, in May, I9or, and Professor White tells us he finds it in the Menai Straits in July, August and September. We have taken it outside the Aberdovey Bar. It ranges from Scandinavia along Western Europe to the Mediterranean, and has also been recorded from Madeira, New Guinea, West Coast of Africa, Cape of Good Hope and Peru. It is distributed all around the British Coast, but especially in the south and west.

\section{Family ScOMbride.}

Scomber scombrus, Linn.-Mackerel.

(Day's British Fishes, vol. I., p. 83, Pl. XXXII and XXXIII.)

(Fish. Mus., Zool. Dep., Univ. Coll., Liverpool.)

This is a gregarious, wandering, pelagic fish which approaches the British coast from the deep water of the North Atlantic in early summer. It spawns in May and June.

Small mackerel generally appear in Cardigan Bay and at the Isle of Man in June, and work round the coast to Anglesey, and then along the north coast of Wales, so as to reach the Liverpool district in July and August, and if the water remains smooth, with winds hanging off the land, the shoals may remain for some time, and large numbers be caught both with lines and stake nets. As soon as a westerly wind sets in and any sea rises, they leave our waters. Only very occasionally are any individuals found here of large size like those found off Kinsale, in the south of Ireland.

They are caught at Formby and other places along the Lancashire coast by stake nets, and in the deeper water by lines. At Holyhead anchored nets are used. They are taken also in Barrow Channel and the Menai Straits. They are more certain to visit the Isle of Man with regularity each season than to reach the Lancashire waters, and they are very abundant in summer outside, and occasionally inside Port Erin Bay.

\section{Scomber colias, Gmel.--Spanish Mackerel.}

(Dạy's British Fishes, vol. I., p. 91, Pl. XXXIV.)

This is a Mediterranean fish (also found off Japan); but stragglers occasionally appear in our seas (Brighton, Swansea, west coast of Ireland, \&c.). It is doubtful whether they ever get further up the Irish Sea than the south of Wales.

Orcynus thynnus (Linn.)-Tunny.

(Day's British Fishes, vol. I., p. 93, Pl. XXXV.)

This, the short-finned Tunny, is a southern and Mediterranean fish, which just reaches our southern coasts, but stragglers occasionally go further north, and have been taken in the 
Clyde, Moray Firth, Firth of Forth, \&c. "Dr. Jacob obtained one 8 feet 3 inches long oft Dublin Bay, in the autumn of $184 \mathrm{I}$, and which weighed fully 300 Ibs."

The long-finned Tunny (Orcynus germo) has much the same distribution as the present species, but has not been recorded for the Irish Sea area.

ThyNNus PELAMYs (Linn.)-Bonito.

(Day's British Fishes, vol. I, p. 100, PI. XXXVII.)

The Bonito, like the Tunnies, is a southern and pelagic fish, and really has its home in the tropical Atlantic; but occasional specimens reach our shores, and have been taken in the Firths of Forth and Clyde, at Plymouth, \&c. Couch records an example found at Whitehaven, in Cumberland, and "in August, 1880, one, 2 feet long, which weighed $6 \frac{3}{4}$ lbs., was secured at Hawgill, Solway Firth" (Day). It has also been taken off the Isle of Man.

ECHENEIS REMORA, Linn.--Remora.

(Day's British Fishes, vol. 1., p. I08, Pl. XXXIX., Fig. 2.)

This fish does not really belong to the British fauna, but has been occasionally brought into our seas by the larger fishes to which it is in the habit of attaching itself by its dorsal sucker. One of these records refers to our district, and is as follows :- "In July, 1848, one was captured at Clontarf, Dublin Bay, adhering to the gills of a blue shark Carcharias glaucus, ten feet long, which had been observed in shallow water and driven ashore the previous night. A second remora was attached to the gills on the opposite side, but when disturbed it disappeared inwards by the branchial orifices, and was not seen again." (Day.)

\section{Family CORYPhenids.}

\section{LAMPris Luna (Gmel.)-0pah.}

(Day's British Fishes, vol. I., p. I 8 , Pl. XLII.)

The Opah, King-fish or Sun-fish, belongs to deep waters, and ranges from Scandinavian seas to the Mediterranean. It is also found in Japanese seas.

It has been recorded from many places round the British coast, including Conway (Couch), Belfast Bay, Wexford, \&c., on the shores of the Irish Sea. Byerley records that a specimen was caught in the estuary of the Dee in 1839 , by a Hoylake fisherman; and the fish has since been taken at Rhos Neigr, on the coast of Anglesey.*

\section{Family Carangide.}

\section{CARANX trachurus (Linn.)-Horse-Mackerel.}

(Day's British Fishes, vol. I., p. I 24, Pl. XLIV.)

The "Scad," or Horse-Mackerel, is a migratory fish, appearing on the British coast from deep water in early summer, but apparently very variable. It rarely comes into the Irish Sea, but Parnell, in 1834 , mentions prodigious numbers being on the Welsh coast. They are much commoner in most years on the Cornwall coast. Our fisheries steamer has taken it when trawling between the Lancashire coast and the Isle of Man.

The species ranges from Norway to the Cape of Good Hope, and has also been found in Chinese and Australian waters, and at Valparaiso-a very wide distribution.

\footnotetext{
* Report of Chester Society of Natural Science for 1900-I (p. 20).
} 


\section{Family CytTide.}

\section{Zeus FABER, Linn.-John Dory.}

(Day's British Fishes, vol. I., p. ${ }_{3}^{8} 8$, Pl. XLVIII.)

(Fish. Mus., Zool. Dep., Univ. Coll., Liverpool.)

The "John Dory" is caught occasionally in the trawl in the warmer month in any part of the district. It is never abundant, nor of large size ; most of those we have seen of late years have been about $\mathbf{5}$ inches in length ; but we have trawled some larger ones in Carnarvon Bay, and between Lancashire and the Isle of Man, e.g., at I4 miles N.W. of Morecambe Bay Lightship in 20 fathoms, in May, Io inches long. Professor White has taken it down to I inch in length in the trawl in Carnarvon Bay in October.

It ranges from Norway to the Mediterranean, but is commonest in British seas on our southern coasts.

\section{Family XIPHIIDÆ. \\ Xiphias Gladius, Linn.-Sword-fish. \\ (Day's British Fishes, vol. I., p. 146, Pl. XLIX.)}

The Sword-fish ranges from Scandinavian seas to the tropical Atlantic and the West Indies. In summer and autumn it appears around the shores of Great Britain, especially in the south and west. It has been recorded from the Bristol Channel and from off the Wexford coast, and so no doubt occasionally enters our area.

\section{Family ScIÆNIDÆ. \\ Sciana aquila, Risso,- Shade-fish. \\ (Day's British Fishes, vol. I., p. I50, P1. L.)}

This fish extends almost from Arctic to Antarctic Seas, and is frequently found on our southern coasts. It has also been recorded from many other places round Britain, including Carmarthen Bay, and occasionally enters our district. It is recorded (by Mr. T. J. Moore) in the stock books of the Liverpool Free Public Museum as having been taken outside the Queen's Channel, Mersey estuary, in October, 1870.

\section{Family GobIIDe.}

Gobius flavescens, Fabr.-Two-spotted Goby.

(See G. ruthensparri, Day's British Fishes, vol. I., p. 16o, P1. LII.)

(Fish. Mus., Zool. Dep., Univ. Coll., Liverpool).

This Goby ranges from Norway and Denmark to the coasts of France. It extends all round the coast of Britain, and has been recorded from our district as being common in the estuary of the Dee, where it lays its eggs inside empty $M y$ shells and guards them from shrimps and other enemies (A. O. Walker), and from Holyhead (Eyton), and Menai Straits (White). We also find it in our other estuaries. It is called by some of the fishermen locally "the Lady-hen," 


\section{Gobius Paganellus, Gmel.-Paganellus.}

(Day's British Fishes, vol. I., p. 162, Pl. LII., fig. 2.)

Probably in rock-pools at Port Erin, and elsewhere. There can be scarcely any doubt that this species is found in our district, though we fear that it has frequently in the past been confused with $G$. niger, and therefore, until a more critical discrimination has been made, we do not like to trust our records.

\section{GobIUS NIGER, Linn.--Rock Goby.}

(Day's British Fishes, vol. I., p. 163, Pl. LII., fig. 3).

This is the largest British Goby, and frequents rocky coasts from Scandinavia to the South of Europe. It is widely distributed round our coast, but not abundant. It is by no means always black, and is liable to be confused with the last species.

In pools at Hilbre Island, at low tide (Byerley, I851), Holyhead (Eyton), Menai Straits (White).

\section{Gobius minutus, Gmel.--One Spotted Goby.}

(Day's British Fishes, vol. I. p. 165, Pl. LII, Fig. 4.)

(Fish. Mus., Zool. Dep., Univ. Coll., Liverpool.) Local name, "Jack Sharp."

This is our commonest Goby, being plentiful along our sandy shores and in pools. Both Byerley and Walker have recorded its abundance in our district. It is constantly caught in the shrimp nets of our estuaries, from the Dee to the Barrow Channel. It extends all around the shores of Europe, chiefly in sandy localities.

Mr. Walker says, "It is common all along the North Coast of Wales and the Dee estuary. It deposits its eggs on the under surface of an empty Mya shell, which it half buries in sand, and then lies under with the head out guarding its nest."

\section{Gobius Parnelli, Day-Speckled Goby.}

(Day's British Fishes, vol. I., p. 167, Pl. LII., Fig. 5.)

This little species extends around the coast of England, and has been recorded in the Solway Firth, the northern boundary of our district.

\section{Gobius pictus, Malm.-Goby.}

\section{(Day's British Fishes, vol. I., p. 167, P1. LIII., Fig. 1.)}

This little Goby ranges from Scandinavian seas to the English Channel, but is rare. A specimen was captured by Mr. A. O. Walker, at Colwyn Bay, on the north coast of Wales, and was sent to Day for description in his book (see p. 168). Some specimens obtained by Mr. Walker in shore pools at Colwyn Bay, in June I894, and sent up to Dr. Günther at the British Museum, were identified by Dr. Günther as being his species G. rhodopterus, but it is still doubtful whether or not that species is merely a synonym of G. pictus. Mr. Walker writes to us (July 1901), that it is "not uncommon in shore pools at Colwyn Bay." Professor White finds it in the Menai Straits.

\section{Gobius JefFreysiI, Günther-Goby.}

(See G. quadrimaculatus, Day's British Fishes, vol. I., p. r68, Pl. LIII.)

(Fish. Mus., Zool. Dep., Univ. Coll., Liverpool.)

This species ranges from Norway to the Mediterranean, but is rare in our seas. A specimen, identified as this species, was obtained on one of our trawling expeditions off the south end of the Isle of Man. 


\section{APHiA PEllucida (Nard.)-Transparent Goby.}

(Day's British Fishes, vol. I., p. 169, PI. LIII., Fig. 3.)

(Fish. Mus., Zool. Dep., Univ. Coll., Liverpool.)

This fish, also called the Nonnat, a French name, goes about in shoals, and occasionally appears in some parts of our district in large numbers. We have obtained them from the Menai Straits, and from Piel Island, in the Barrow Channel, where it has been taken along with shoals of young herring. Professor White found it in great abundance in Menai Straits in 1897 , but since then only stray individuals have been taken.

The species ranges from Norway to the Mediterranean and Black Sea.

\section{Family Callionymide.}

\section{Callionyus lyra, Linn.-Dragonet.}

(Day's British Fishes, vol. I., p. 174, Pl. LIV.)

(Fish. Mus., Zool. Dep., Univ. Coll., Liverpool.)

This beautiful little fish is variously known as the Gemmeous Dragonet, the Dusky Skulpin, and by some fishermen, locally, the "Bishop."

It extends from Norway to the coasts of France, and is common round our coasts. In this district it is captured in the shrimp and fish trawls. The females seem to be commoner on the shrimping grounds than the males. We find it frequently at the mouth of the Mersey, and in our other estuaries, and have taken it also in the Barrow Channel, the Menai Straits, and at the mouth of the Dee, in shrimp trawls. It is frequently taken in the dredge inside and especially outside Port Erin Bay.

\section{Family Discoboli.}

Crclopterus lumpus, Linn.-Lumpsucker.

(Day's British Fishes, vol. I., p. 179, Pl. LV.)

(Fish. Mus., Zool. Dep., Univ. Coll., Liverpool.) Local name, "Hen-fish."

The Lumpsucker, or Hen Fish, is on the whole a northern fish, ranging from Arctic Seas (Iceland) to the northern parts of France. In our seas it is commonest off the Scottish coasts, but has also been recorded at various places round the English and Welsh coasts. In our district it is not uncommonly cast ashore. We have found it at Hoylake and Hilbre Island, at the Isle of Man, in Morecambe Bay, and in the Dee estuary. Mr. Walker tells us he has found it at Colwyn Bay and at Rhos Weir. It is sometimes taken in the shrimp nets in our estuaries. It has been found as far up the Mersey as Tranmere, above Birkenhead. It is also found in the Barrow Channel, round Piel, in the Menai Straits, and is occasionally taken on long lines around the Calf, Port Erin, in early spring.

\section{Liparis vUlgaris, Flem.-Sea-snail.}

(Day's British Fishes, vol. I., p. I84, Pl. LVI., Fig. I.)

(Fish. Mus., Zool. Dep., Univ. College, Liverpool). Local name, "Sucker."

This common Sea-snail, or Sucker, ranges from Arctic Seas to the coast of France. It seems to be commoner in Scotland than with us, but is found in various parts of our district. It has been taken as far up the estuary of the Mersey as between the Dingle and Garston in a 
shrimp trawl (A. Scott.) "Very often taken in shrimp nets and in pools at low tide" (Byerley.) We have also taken it in Morecambe Bay in the shrimp trawl, and in the Menai Straits. It is also occasionally found under stones and amongst Laminaria in Port Erin Bay. We find that it feeds on the shank (Pandalus annulicornis).

\section{Liparis montagui (Don.)-Montagu's Sucker.}

(Day's British Fishes, vol. I., p. I86, Pl. LVI., Fig. 2.)

(Fish. Mus., Zool. Dep., Univ. Coll., Liverpool.)

Montagu's or the diminutive Sucker is commoner on our southern coasts than Liparis vulgaris. It is not uncommon on our shrimping grounds. We have taken it in the shrimp trawl off Formby, in the Rock Channel, Liverpool, and in other places in our estuaries. It has also been recorded from Holyhead (Eyton), the Dee estuary (Walker), and A. Scott has taken it in the shrimp trawl between the Dingle and Garston on the Mersey, along with the last species, in December, 1894 .

\section{Family Gobiesocid $x$.}

\section{Lepadogaster bimaculatus (Don.) -Double-spotted Sucker.}

(Day's British Fishes, vol. I., p. 192, Pl. LVII., Fig. 3.)

(Fish, Mus., Zool. Dep., Univ. Coll., Liverpool.)

This species ranges from Scandinavia to the Mediterranean. It has been recorded in Belfast Lough, Strangford Lough, and elsewhere on the shores of the Irish Sea; it is common in Port Erin Bay, and must occur in other parts of the district.

\section{Lepadogaster govanil (Lacép.)-Cornish Sucker.}

(Day's British Fishes, vol. I., p. 189, Pl. LVII., Fig. 1.)

(Fish. Mus., Zool. Dep., Univ., Coll., Liverpool.)

This little species is common in Port Erin Bay and must also occur elsewhere in the district.

\section{Lepadogaster decandolil, Risso--Connemara Sucker.}

(Day's British Fishes, vol. I., p. I91, Pl. LVII., Fig. 2.)

This rarer species is occasionally taken in Port Erin Bay.

\section{Family BlenNIDA.}

ANarrhichas lupus, Linn.-Wolf-fish.

(Day's British Fishes, vol. 1., p. 195, Pl. LVIII.)

This is a northern form, and is commoner in the North Sea and along the East coast than with us, and is not uncommon in the Clyde district. It has, however, been recorded from Belfast, Dublin Bay, and other points round the shores of the Irish Sea. It is recorded in the Liverpool Free Public Museum from "the Rock Buoy, Irish Sea, 4/2/78"; and we have a specimen in the University College Museum, which is possibly local.

Prof, White tells us that he finds young specimens in the Menai Straits, 


\section{Blennius Gattorugine, Bloch.-Gattorugine.}

(Day's British Fishes, vol. I., p. 198, PI. L.IX.)

This fish was first found off Anglesey by Pennant; also Holyhead (Eyton); but we have no certain records of its capture since.

Blenvius galerita, Linn.-Montagu's Blenny.

(Day's British Fishes, vol. I., p. 200, P1. LX., Fig. 1).

Once captured in the creek dividing Holyhead Island from Anglesey (Eyton).

BLENNiUs ocellaris, Linn.-Butterfly Blenny.

(Day's British Fishes, vol. I., p. 20I, P1. LIX., Fig. 2.)

(Fish. Mus., Zool. Dep., Univ. Coll., Liverpool.)

This species ranges from the British Isles to the Mediterranean. It has only been found at a few places in our seas, but "is recorded as having been dredged up on a scallop bank, in twenty fathoms of water, off Ballaugh, in the Isle of Man, in June, $18_{34}$ " (Forbes). A single specimen was trawled from our Lancashire Fisheries steamer "John Fell," I 5 miles W. by N. of Morecambe Bay Lightship, on May 29th, 1894, and was sent by Captain Wignall to our Fisheries Laboratory, at Liverpool, where it was identified by Mr. A. Scott.

Blexius PHolis, Linn.--Shanny.

(Day's British Fishes, vol. I., p. 203, Pl. LX.)

(Fish. Mus., Zool. Dep., Univ. Coll., Liverpool.) L Local name, "Shanny."

This common species ranges from Scandinavia to the Mediterranean. It is found almost everywhere in pools between tide-marks round the British coast. It is one of the commonest of shore fishes in our neighbourhood, both on the Lancashire side, and at Port Erin and elsewhere in the Isle of Man, and in rock pools in North Wales and Anglesey; also in the Barrow Channel.

It is interesting to "notice that Pennant found it to be common in Anglesey, and that Donovan "observed that in the 30 years that had elapsed since Pennant's remarks were published, he found it had disappeared (except in one spot), and this he attributed to the tangle having been almost eradicated for the use of glass-makers, \&c."

Carelophus ascanir (Walb.) - Yarrell's Blenny.

(Day's British Fishes, vol. I., p. 206, P1. LX., Fig. 2.)

(Fish. Mus., Zool. Dep., Univ. Coll., Liverpool.)

This fish ranges from Scandinavia to the British Isles. Although rare, it has been recorded from many points round our coasts, several of which are off the east coast of Ireland.

\section{Pholis gunNellus (Linn.)-Butterfish.}

(See Centronotus gunnellus, Day's British Fishes, vol. I., p. 208, P1. LXI., Fig. r.)

(Fish. Mus., Zool. Dep., Univ. Coll., Liverpool.) Local Name, "Butterfish."

This common little fish extends from Iceland and Greenland to the shores of France. It is abundant all round our coasts in shore pools, and under stones between tide marks. 
It is also sometimes caught in our shrimp nets. We have it commonly at Port Erin and elsewhere in Isle of Man, Menai Straits, north coast of Anglesey, North Wales, and Piel in the Barrow Channel.

\section{ENCHelyopts viviparus (Linn.)-Viviparous Blenny.}

(See Zoarces viviparus, Day's British Fishes, vol. I., p. 2 I , Pl. LXI., Fig. 2.)

This fish ranges from Scandinavia to the south of Europe. It seems commoner on the Scottish coast than here, but has been recorded from Co. Down, on the Irish side of our district. We have not yet found it in Lancashire, but it occurs on the Welsh coast-"Holyhead and Barmouth common" (Eyton); and Professor White tells us that he has seen "one or two specimens" at the Menai Straits.

\section{Family Atherinide.}

Atherina presbyter, Cuv.-Atherine.

(Day's British Fishes, vol. I., p. 225, Pl. LXV., Fig. 1.)

This is a southern form ranging to the Mediterranean, but probably not further north than Scotland. It is found in Co. Down and other localities on the western side of our district and, Professor White tells us, he has had it from the Menai Straits.

\section{Family MugiLide.}

\section{Múgir, chelo, Cuv.-Lesser Grey Mullet.}

(Day's British Fishes, vol. I., p. 232, Pl. LXVII.)

(Fish. Mus., Zool. Dep., Univ. Coll., Liverpool.) Local Name, "Mullet."

This fish has a wide range, from Scandinavia to the Mediterranean and Madeira: It is gregarious, and is especially abundant in estuaries. It is found and fished for throughout our district. It is caught in stake and seine nets at Southport, and at Piel in the Barrow Channel. There is also a fair fishery for. it in North Wales, where it is taken in draft nets, and sometimes in the estuary of the river Dorey. It is also taken in autumn, in Port Erin Bay, commonly in October. Between June and September large numbers come into the seatlake at Cemlyn, on the north of Angleser.

\section{Family Gasterosteide.}

Gastekosteus aculeatus, Linn.-Three-spined Stickleback.

(Day's British Fishes, vol. I., p. 238 , Pl. LxVIII.)

(Fish. Mus., Zool. Dep., Univ. Coll., Liverpool.) Local name, "Jack Sharp."

This semi-marine species has been recorded from Belfast Lough and other spots on the Irish side of our area, and also occurs at Piel, in the Barrow Channel, in the Menai Straits, and at various other points on our coast, as well as up the streams.

Gasterosteus pungituus, Linn.-Ten-spined Stickleback.

(Day's British Fishes, vol. I., p. 244, Pl.; LXVIII, Fig. 4.)

This species occurs along with the last on both shores of the Irish Sea. It has been recorded from various places in Co. Down and also in Lancashire. 


\section{Gasterosteus spinachia, Linn:-Fifteen-spined Stickleback.}

(Day's British Fishes, vol. I., p: 246, Pl. LXVIII, Fig. 5.)

(Fish. Mus., Zool. Dep., Univ. Coll., Liverpool.) Local name," "Jack Sharp."

This is more of a marine species than the last two. It ranges from the Bartic to the Bay of Biscay. It has been recorded from Anglesey; from pools amongst rocks at Hilbre Island, Caldy Blacks, \&c. (Byerley); and we have had it from Morecambe, Menai Straits, and the Barrow Channel. It is common in Port Erin Bay in summer.

\section{B. PHARYNGOGNATHI.}

Right and left lower pharyngeal bones fused with each other to form a single bone in floor of mouth.

This little section includes the Wrasses, and is distinguished from the last group by the fused condition of the lower pharyngeal bones in the floor of the mouth.

\section{Family LABRIDæ.}

\section{Labrus maculatus, B1.-Ballan Wrasse.}

(Day's British Fishes, vol. I., p. 252, Pl. LXX, and LXXI.)

(Fish. Mus., Zool. Dep., Univ. Coll., Liverpool.)

This Wrasse is distributed from Scandinavia to the Mediterranean.

It has been recorded from the Skerries, Anglesey (Donovan), and Colwyn Bay on the North Wales coast; and we find it at Piel in Barrow Channel, and in the Menai Straits. It is occasionally taken by our Fisheries steamer on the off-shore grounds between Lancashire and the Isle of Man.

\section{LABRUS MIXtus, Fries and Eks.-Cook Wrasse.}

(Day's British Fishes, vol. I., p. 256, Pl. LXXII.)

(Fish. Mus., Zool. Dep., Univ. Coll., Liverpool.)

This species ranges from Scandinavia to the Mediterranean.

In our district it has been, recorded from Anglesey (Pennant), and from the Manx coast. It is abundant in and around Port Erin Bay in summer. We have seen it brought into Fleetwood by trawlers.

Crenilabrús Melops (Linn.)-Gilt-head.

(Day's British Fishes, vol. I., p. 260; Pl. LXXIII.)

(Fish. Mus., Zool. Dep., Univ. Coll., Liverpool.)

This fish-is sometimes called Baillon's Wrasse, or Sea-partridge, sometimes the Gilt-head or Gold-sinny. It ranges from Norway to the Mediterranean. Byerley records a specimen taken at Hoylake in $185^{\circ}$.

CteNolabrus RUPESTRIS (Linn.)-Gold-sinny.

(Day's British Fishes, vol. 1. p. 264, P1. LXXIV.)

It - ranges from Norway to the Mediterranean. North Wales (Eyton); shore near Aberystwyth ; also Liverpool Bay. 


\title{
Centrolabrus exoletus (Linn.)-Rock Cook.
}

\author{
(Day's British Fishes, vol. I., p. 267, Pl. LXXVI.)
}

(Fish. Mus., Zool. Dep., Univ. Coll., Liverpool.)

We have taken this species two miles east of Port St. Mary, in the Isle of Man (February 2nd, 1896).

\section{ANACANTHINI.}

There are no spines on the dorsal, anal and pectoral fins; the fin rays are soft, and jointed; the pelvic fins, if present, are far forward in a thoracic or jugular position ; the air bladder, if present, has no duct.

This is a most important group of fishes, as it includes the two great tribes of food fishes, the cod family and the flat fishes.

\section{Family GaDID}

One of the most important families of fishes from the economic point of view.

Gadus callarias, Linn.--Cod.

(Day's British Fishes, vol. I., p. 275, Pl. LXXVIII.)

(Fish. Mus., Zool. Dep., Univ. Coll., Liverpool.) Local names, "Cod" and "Codling."

The cod is probably the most useful of all fishes to man. No part of the body seems valueless. In additition to its prime importance as a food, oil is extracted from the liver, the head, tongue and sounds can be made to form a good article of food, the offal and bones, when steamed, dried and ground up, are converted into very good manure, said to be equal as a fertilizer to Peruvian guano, the roe is a splendid bait used in the sardine fisheries of France and Spain, and from the swim-bladder isinglass is made.

It comes from deep water into the Irish Sea in the late autumn in order to spawn about the beginning of the year, and the chief fishery is during the winter. It is sometimes very abundant at the mouth of the Dee, and very large takes are at times made along our coast by the steam trawlers. Although at one time a valuable line fishery flourished along the Lancashire coast, the cod is now caught mostly in the trawl from Lancashire, and still wholly by lines in the Isle of Man. Large numbers are taken by the long lines around the Calf, Port Erin, in winter and early spring. These lines are baited with whelks taken in pots, and usually the cod are caught by lines earlier in the season than their capture in the trawl. In some places lug-worms are also used as bait, especially in lines set near shore. The trawling is most successful at night and during the cold months of the year (Nov. to April). The young are taken as "Codling" on various parts of our shores, in the Barrow Channel, Menai Straits, \&c.

The spawning in spring takes place in the offshore waters, and the young cod does not appear on the coasts till June, when it is about an inch long. It frequents rocky and seaweedy shores till the autumn when it moves out again into deeper water. 
Gadus aeglefinus, Linn.-Haddock.

(Day's British Fishes, vol. I., p. 283, Pl. LXXIX.)

(Fish Mus., Zool. Dep., Univ. Coll., Liverpool.)

This is a valuable food fish in this district, although it is to some extent variable, occasionally disappearing for a term of years. It has visited the Lancashire coast in large numbers for the last few years, but is now apparently leaving. About twelve years elapsed between the last visit and the previous one.

In our district, it has been most plentiful, when present, during the last four months of the year. It is caught with the trawl. Last year the value of the fishery was $£ 35,000$. It is frequently taken on long lines round the Calf Island, Port Erin.

\section{Gadus Luscus (Will.) - Whiting-pout or Bib.}

(Day's British Fishes, vol. I., p. 286, Pl. LXXX.)

(Fish Mus., Zool. Dep., Univ. Coll., Liverpool.)

This species ranges from Scandinavia to Italy.

It has been recorded on the Carnarvonshire coasts and Menai Straits, and we take it occasionally in the trawl net in our district. We also have it from Port Erin bay, 12 inches in length. It is not uncommon there in winter.

Gadus minutus, Linn.-Poor-cod.

(Day's British Fishes, vol. I., p. 288, P1. LXXXI.)

(Fish. Mus., Zool. Dep., Univ. Coll., Liverpool.)

This little species ranges from. Scandinavia to the Mediterranean. It occurs in our district, and we take it frequently with other fish in the trawl, in deeper water, all the year round, but never many at a time. Byerley writes in regard to its occurrence near Liverpool: "Very abundant early in August, 1854 , as many as 5 or 6 having been seen in a single pool at ebb-tide. They have since increased greatly in numbers, poor persons gathering them in sufficient quantities for food. I have seen them also at Hilbre Island."

Gadus merlangus, Linn.-Whiting.

(Day's British Fishes, vol. I., p. 290, P1. LXXXII.)

(Fish. Mus., Zool. Dep., Univ. Coll., Liverpool.)

The Whiting ranges from Scandinavia to the Mediterranean. It is usually abundant in our district, but during the last few years has been rather scarce in Lancashire waters. Before that it was very abundant. This year (1901) there are plenty on the Welsh Coast about Aberystwyth.

The whiting is a winter fish, and is caught in the trawl mainly from December to February. Large quantities of the immature young are frequently taken in shallow water with the shrimp nets. We have taken nearly six thousand in one haul, in August, in the Crosby Channel, all about 4 inches long.

Gadus virens, Linn.-Coal-fish.

(Day's British Fishes, vol. I., p. 293, Pl. LXXXIV.)

(Fish. Mus., Zool. Dep., Univ. Coll., Liverpool.) Local name, "Bluffin" (for young),

"Bloghan" in Isle of Man.

This fish ranges from the Arctic seas (Spitzbergen) to the Mediterranean. It is common off our rocky coasts, and is very abundant round the Isle of Man, It is taken in the 
trawl throughout the district, but not in abundance. Walker records it as being present, but not very common, at Colwyn Bay and Rhos Weir. It is also taken in the Menai Straits and off the North Wales coast, and round Piel in the Barrow Channel. - Large numbers are often caught in autumn off Port Erin with lines, and also with drag nets in the bay, which they are said by the fishermen to enter in pursuit of herring fry.

\section{GADUS POLLACHIUS, Linn.--Pollack.}

(Day's British Fishes, vol. I., p. 296, Pl. LXXXIII., Fig. 2.)

The Lythe or Pollack ranges from Scandinavia to the Mediterranean.

In our district it is abundant off the Coast of Wales and round the Isle of Man. It is found in plenty in the Menai Straits. It is caught chiefly by lines. Byerley says "caught, but not frequently, by the Hoylake fishermen" (1854). It is common at Port Erin, especially in autumn. We have taken the young from 4 to 6 inches in length on the Blackpool closed ground in December.

\section{Merluccius vulgaris, Cuv.-Hake.}

(Day's British Fishes, vol. I., p. 300, Pl. LXXXV., Fig. I.)

The range is wide-from Arctic Seas (Greenland) to the Mediterranean and Madeira.

This fish is not abundant in the greater part of our district. Few are found in Lancashire waters, and on the Welsh coast. But it is trawled in fair quantity to the west and south of the Isle of Man. It is usually taken on long lines round the Calf Island. We found it in abundance there in April, 1896 . Large numbers are taken by the steam trawlers near the "Smalls" Lighthouse, at the southern end of our area.

\section{Phycis Blennoides (Brün.)-Forked Hake.}

\section{(Day's British Fishes, vol. I., p. 303, Pl. LXXXV., Fig. 2.)}

Ranges from Scandinavia to the Mediterranean. This fish only comes to our coasts during the winter. It has been recorded off the Flintshire coast, North Wales; and we have taken it from deep water off the Isle of Man. Mr. Walker found it in Rhos Weir on April 24th, I888-the specimen is now in the Grosvenor Museum, Chester. He tells us that only three specimens have been taken in the Weir in 35 years.

\section{Molva vulgaris, Flem.--Ling.}

(Day's British Fishes, vol. I., p. 305, Pl. LXXXVI.)

Although the Ling ranges from Spitzbergen to the Mediterranean, it is in the main a northern fish, and is very common in the north of Scotland. It is not abundant in our district, but is occasionally taken with the trawl, and occasionally with lines, at any time of year. It is taken on the long. lines round the Calf, Port Erin ; also at Cemlyn, on north of Anglesey.

\section{Onus mustela (Linn.)-Five-bearded Rockling.}

(See Motella mustela, Day's British Fishes, vol. I., p. 314,Pl. LXXXVIII., Fig. 2.)

(Fish. Mus., Zool. Dep., Univ. College, Liverpool.)

This species ranges from Iceland to the south of Europe. It is found round most parts of the British coasts. Byerley records it as found in the Mersey near Hale, and as taken occasionally by Hoylake fishermen. We have also obtained it from Hoylake, from Newcombe 
Knowl Buoy, from Menai Straits and Colwyn Bay, from Port Erin, in the Isle of Man, and trom Piel, in the Barrow Channel. We find it under stones at low tides at Spaldrick, Port Erin.

\section{Onus cimbrius (Linn.)-Four-bearded Rockling.}

(See Motella cimbria, Day's British Fishes, vol. I., p. 316, PI. LXXXIX., Fig. I.)

This species is a northern form, rare in the British Islands. Mr. E. W. L. Holt has recorded it from the Bristol Channel. It probably extends up the Irish Sea.

\section{ONUS TRICIRRATUS (B1.)--Three-bearded Rockling.}

(See Motella tricirrata, Day's British Fishes, vol. I., p. $3^{1} \%$, Pl. LXXXVIII, Fig. 1.)

(Fish. Mus., Zool. Dep., Univ. Coll., Liverpool.)

This Rockling ranges from Norway to the Mediterranean. It has been recorded from North Wales, from the estuary of the Dee, and from various localities on the east coast of Ireland. We have had specimens from Hoylake and Hilbre Island, and from Piel, in the Barrow Channel. Is is not uncommon in Port Erin Bay.

\section{RanicePs Raninus (Linn.)--Tommy Noddy.}

(Day's British Fishes, vol. I., p. 320, Pl. XC.)

This is a northern form, rarely extending south of the British Isles. "It was first described from an example taken at Beaumaris, in Wales, by Mr. Davies," and Professor White tells us that he has a specimen caught on aline in the Menai Straits.

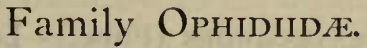

Ammodytes lancelatus, Lesauv. -Greater Sand-eel.

(Day's British Fishes, vol. I., p. 329, P1. XCII., Fig. I.)

(Fish. Mus., Zool. Dep., Univ. Coll., Liverpool.)

This form extends from northern Europe to the Mediterranean. It is not so common in our seas as the smaller sand-eel, but has been recorded from localities on the east coast of Ireland, and in the estuary of the Dee, and Menai Straits; and we have seen a specimen obtained in Morecambe Bay, and one from the sand close to the Biological Station at Port Erin.

Ammodytes tobianus, Linn.-Lesser Sand-eel.

(Day's British Fishes, vol. I., p. 33I, Pl. CXII, Fig. 2.)

(Fish. Mus., Zool. Dep., Univ. Coll., Liverpool. Local name, "Sand-eel"

The range is practically the same as the last species, but this smaller form, or sandlaunce, is much commoner in our seas. At Fleetwood, and other places on the Lancashire coast, there is a fishery for it in summer. It is dug out of the sand with spades, old sickles, and other implements, and is also caught in the shrimp trawl. Taken in Barrow Channel, in Menai Straits, and very abundant at Port Erin in autumn. It is frequently taken in our Lancashire estuaries with shrimp nets.

\section{Family Pleuronectide.}

The fiat-fish family, which inclucles the Turbot, the Plaice, and the Sole, is not only one of the most important families from the economic point of view, but is also one of 
the most remarkable because of the curious metamorphosis which transforms the symmetrical, evenly-developed young fish into the flattened, unsymmetrical adult. The body is flattened from side to side, and the animal lies with one side, usually the left, on the bottom. The head is twisted, so that both eyes come to be on the upper surface, which is darkly pigmented, while the lower side is white. The dorsal fin grows forward along one side of the head, and does not lie between the eyes. The two flattened surfaces are really the right and left sides of the animal. There is a pectoral and a pelvic fin, and a gill-cover on each, just as in the case of an ordinary fish such as the cod or herring.

In most of our flat fishes it is the right-hand side of the body which is uppermost, and bears the eyes; but in the turbot and brill, the megrim and the scald fish, and the three species of Top-knots, the left side is the one that is uppermost, is pigmented, and bears the eyes. In all the eggs are pelagic-small, buoyant, and transparent.

\section{Hippoglossus vulgaris, Flem.-Halibut. \\ (Day's British Fishes, vol. II., p. 5, P1. XCIV.)}

The halibut is a northern fish, ranging from Arctic seas down to the English Channel, and, although found all round our coast, is more abundant off the Scottish coast than in our sea. "Pennant mentions it from the Menai Straits, and in April, 1829, an example $7 \frac{1}{2}$ feet long, and $320 \mathrm{lb}$. weight was recorded from off the Isle of Man-Mag. Nat. Hist. I 829, i. p. 84 " (Day). Byerley states that the Hoylake fishermen take one or two in a year; and we hear of it as taken occasionally to the east of the Isle of Man. It is also occasionally still taken by the Hoylake and Fleetwood trawlers, but must be regarded as very scarce in our waters.

\section{Drepanopsetta platessoides (Fabr.)-Long Rough Dab.}

(See Hippoglossondes limandoides, Day's British Fishes, vol. II., p. 9, Pl. XCV.)

(Fish. Mus., Zool. Dep., Univ. Coll., Liverpool.)

This is apparently a fish of somewhat restricted range - the North Sea and neighbouring shore of north-western Europe. It is commonest on the east coast of Scotland, and is rare in our district, where there is no fishery for it. Byerley records it as "rare near the shore, more frequent in deep water." Prof. White tells us he has found it in the Menai Straits ; and we took one specimen from the "John Fell," in March, 1895, in " the Hole," Irish Sea.

\section{Rhомвus maximus (Linn.)-Turbot.}

(Day's British Fishes, vol. II., p. II, Pl. XCVI.)

(Fish. Mus., Zool. Dep., Univ. Coll., Liverpool). Local name, "Turbot."

The Turbot ranges from the north of Europe to the Mediterranean, and is fished all round our coast. In the Irish Sea it frequently occurs in the trawl all over the district, on the off-shore grounds, and at all times of year. It is most commonly taken at night. The young from 2 to 8 inches in length are caught in the shrimp nets in shallow water (we have taken them 2 inches long in the Blackpool closed ground in January), and rather larger ones in fish trawls along the banks. It is also taken in Barrow Channel, and along the Cardigan coast, and is not uncommon round the Isle of Man. Turbot are occasionally taken in Port Erin Bay, close to shore, with the drag net; one weighing $8 \frac{3}{4} \mathrm{lbs}$. was caught in October, 190r. Prof. White tells us it is caught occasionally in the weir in the Menai Straits, one caught there last summer weighed $14 \mathrm{lbs}$. 
Rhombus Lavis, Rondel.-Brill.

(Day's British Fishes, vol. II., p. I4, Pl. XCVII.)

(Fish. Mus., Zool. Dep., Univ. Coll., Liverpool). Local name, "Brett."

The Brill, or Brett, ranges from Shetland to the Mediterranean. It is most abundant on our southern coasts; but many are taken with trawls along with the turbot. It is usually more numerous than the turbot, both on the Lancashire coast, in-shore and off-shore grounds, and also in Cardigan Bay to the south. It is taken in the Barrow Channel, Menai Straits, also off Port Erin and neighbourhood, where it is said by fishermen to be much less common than formerly. We have taken the young down to 3 inches in length on the Blackpool closed ground in January.

\section{Scophthalmus noRvegicus, Günth.-Norwegian Top-knot. (Not in Day's British Fishes.)}

(Fish. Mus., Zool. Dep., Univ. Coll., Liverpool.)

This is a northern fish which ranges from Norway down to the English Channel.

It has been found recently in our seas on several occasions :- by Mr. Ernest Holt from the west coast of Ireland, and by Cunningham near Plymouth. We have a specimen in the Collection at University College, Liverpool, which was obtained in the district. It measures three inches in length.

\section{Scophthalmus unimaculatus (Risso.)-Bloch's Top-knot.}

(See Zeugopterus unimaculatus, Day's British Fishes, vol. II., p. 17, Pl. XCIX.)

(Fish. Mus., Zool. Dep., Univ. Coll., Liverpool.)

This little fish ranges from Denmark to the Mediterranean, but is very rare round the British coast. It has been taken a couple of times off Belfast; it is recorded (by Mr. T. J. Moore) in the books of the Liverpool Public Museum as being obtained "from Manx fishing boats" ; and we have two specimens which were trawled from the Fisheries Steamer "John Fell," on 17th May, 1894, at 1o miles W. $\frac{1}{2}$ N. from Morecambe Bay Light-ship, at a depth of 23 fathoms. These pretty little fish differ in some points from the figure given by Day, especially in the position of the spot, and in the length of the dorsal and ventral fins which, as in Z. punctutus, pass under the tail. In these two points our specimens agree perfectly with the figure and description given by the late Mr. George Brook in the Fourth Ann. Rep. Fishery Bd. for Scotland, p. 225, Pl. IX., as has been pointed out to us by Mr. Andrew Scott.

\section{Zeugopterus punctatus-(B1.) - Muller's Top-knot. \\ (Day's British Fishes, vol. II., p. I8, Pl. C.) \\ (Fish. Mus., Zool. Dep., Univ. Coll., Liverpool.)}

This species ranges from the North of Europe to France. It is the commonest of the little "Top-knots" in our seas. It has been recorded from all round the British coast, including several places in our area :-Anglesey (Gosden), neighbourhood of Mersey (Byerley, 1851 , and we have taken it at the south end of the Isle of Man.

\section{Lepidorhombus Megastoma (Donovan.)-Megrim.}

(Day's British Fishes, vol. II., p. 2I, Pl. XCVIII.)

(Fish. Mus., Zool. Dep., Univ. Coll., Liverpool.) Local name, "Megrim."

This species, variously called the Megrim and the Sail fluke, ranges from the North of Europe to France. It is very scarce on the Lancashire coasts, but still is got there occasionally. Pennant records it from Flintshire, Byerley from off the Dee, and White from 
the Menai Straits. It is much more plentiful, however, to the West and S.W. of the Isle of Man in deep water, on the mud. There it is trawled all the year round, but is taken chiefly in summer. In size it extends up to about 18 inches.

\section{Arnoglossus laterna (Walb.)-Scald-fish.}

(Day's British Fishes, vol. II., p. 22, Pl. XCIX., Fig. 2.)

(Fish. Mus., Zool. Dep., Univ. Coll., Liverpool.) Local Name, "Scald-fish."

This smaller form, the Scald-fish, ranges from Norway to the Mediterranean. It is sometimes abundanit between the Isle of Man and Ireland, and less frequently on the east coast. Byerley recorded it from mouth of Dee in 1854 . We occasionally dredge it still off the mouth of the Dee.

The size we find it here is only up to about 7 inches.

\section{Pleuronectes platessa, Linn.--Plaice.}

(Day's British Fishes, vol. II., p. 25, P1. CI.)

(Fish. Mus. Zool. Dep., Univ. Coll., Liverpool). Local Nume, " Plaice-fluke."

The plaice is easily distinguished by its orange-red spots, by the small smooth scales, by the rough bony ridge extending back between the eyes, by the straight lateral line and by the wide, flattened teeth. There are also strong crushing teeth in the throat, by means of which it breaks the shells of the bivalves, such as Mactra and Donax, upon which it largely feeds.

This important fish ranges from Iceland to the South of Europe, and is common all round our coasts. Plaice vary greatly in their average size in different localities, and there are probably several distinct races. Those from the north are, as a rule, the largest. In the Irish Sea the plaice is mature at about 13 to ${ }_{15}$ inches for the female, and 1 I inches for the male. The plaice is a great source of income to the inshore trawler. It is not only found on the fishing grounds lying off the coast but is also taken in large numbers in the bays, estuaries, and channels-in fact this fish is to be found on nearly every fishing ground inside the District as well as outside the boundary line in the Irish Sea. The spawning grounds, like those of the sole, lie at long distances from the shore (see above, p. $3^{1}$ ).

The plaice is taken to a large extent by the use of the trawl net, but there are also a great number of stake-nets used in the capture of this fish; these are set on the sands, in the bays and estuaries, and in some cases the nets formerly extended to a length of over 1,000 yards, but are now reduced to 300 yards owing to the action of the Fisheries Committee. These nets are set in different forms, some being in the shape of a semi-circle, and others with two straight arms, one long and the other a short one, with a poke or bag in the centre. The arms guide the fish coming off the banks into the bag, and here the force of the tide passing through the bag keeps them secured until the net runs dry. Plaice are also taken on hooks and lines, and by the use of tees, i.e., a line with horse hair snooding with ordinary pins attached instead of hooks; the bait, generally worms, is threaded on the pin, and, when swallowed by the fish, the pin is released and gets across the throat of the fish, which it secures. Hedge baulks-fixed implements of large capacity made of watling, with a trap or cage in the centre-are also used for taking plaice (see Fig. 10). Stream nets, instruments made of netting, fixed on stakes and set across the channels and streams, were formerly in use, 
but are now abolished under the Bye-Laws as destructive engines. Draw nets are permitted, but all nets have now to be made to a specified size of mesh, in order to allow of the escape of the smaller fish. Of late, plaice cannot be said to have increased in numbers along this coast, but this is, we think, attributable to over fishing; for, besides fixed instruments for their capture, a very large fleet of boats works amongst them inshore, and the deep-sea sailing trawlers and steam trawlers fish for them outside the boundary line of the district. Plaice are therefore taken in the Irish Sea in many ways, on various grounds, all the year round; and very large numbers of the young are destroyed. We have taken over ten thousand, all about $4 \frac{1}{2}$ inches long, in one haul of the shrimp trawl off the mouth of the Mersey in September.

\section{Pleuronectes microcephalus, Don.-Lemon Dab.}

(Day's British Fishes, vol. II., p. 28, Pl. CII.)

(Fish. Mus., Zool. Dep., Univ. Coll., Liverpool.) Local name, "Lemon Sole."

This fish, distinguished by its oval shape, its small head and mouth, and its rich yellow colour marked with brown, is known by many local names in addition to lemon sole, such as smear dab and merry sole. It is a northern fish mainly, and ranges from Iceland to France, and is found all round our coast, especially in the deeper waters. It is fished in fair numbers in some parts of our district, such as off the Isle of Man, in Cardigan Bay, and in Red Wharf Bay, Anglesey. We also have it recorded from the mouth of the Dee (A. O. Walker), and from the Barrow Channel and Menai Straits, as well as from our offshore trawling grounds, e.g., between the Morecambe Lightship and the Isle of Man, where it is in fair numbers. It spawns between March and August, 20 miles or more from land, and we have found it spawning in our district chiefly in April and May. A ripe male and a half-spent female, both trawled on May 19th, 1893, at 20 miles N.W. of Morecambe Bay Lightship, measured both of them $9 \frac{1}{2}$ inches. The ova, when laid, measure $14 \mathrm{~mm}$. in diameter, and hatch out in about a week. We have used this fish for hatching experiments on occasions at the Port Erin Biological Station.

Pleuronectes limanda, Linn.-Dab.

(Day's British Fishes, vol. II., p. 3I, Pl. CIV.)

(Fish. Mus., Zool. Dep., Univ. Coll., Liverpool.) Local name, "Sand Scar" or "Garve."

The common Dab has spiny scales, which make the skin rougher than in the Plaice, and the ridge between the eyes is smooth; but the best easily seen characteristic of the Dab is the nearly semi-circular curve of the lateral line behind the head.

This fish ranges from the north of Europe to the French coast, and is abundant on sandy ground round the British Isles. It is very common in the Irish Sea, where it is often known by the local name of "Garve," or "Garve fluke." In our district the food of the Dab is chiefly mollusca: It is taken principally by the trawl net, but also by the use of tees (see under Plaice, above), and to a certain extent in stake nets. It is generally found in the same grounds with the plaice, and spawns, like the plaice, in deep water at a distance from shore, usually 20 to 30 miles off land in the Irish Sea. On the spawning ground we find large numbers of dabs, from $4 \frac{1}{2}$ to I I or 12 inches in length, congregated; the average size is about 8 or 9 inches. It spawns from March to May or June. Out of a large number we have examined we find that the smallest ripe female (in April) we have found was $5 \frac{1}{2}$ inches, and the smallest ripe male 5 inches, while the smallest spent female (in May) was $5 \frac{3}{4}$ inches, and the smallest spent male $5 \frac{1}{2}$ inches; but the majority of the ripe and spent fishes are from 8 to to 
inches long. The female produces about 100,000 ova at a time. The egr is small, about $0.8 \mathrm{~mm}$. in diameter, and hatches in anything from 3 to say 12 days, according to the temperature of the water. By many, especially by fishermen, and those living near to or at the fishing centres, as a food it is thought equal if not superior to the plaice ; but the market price is much less, and it is therefore not sought after to the same extent as the plaice.

\section{Pleuronectes flesus, Linn.-Flounder.}

(Day's British Fishes, vol. II., p. 33, Pl. CV.)

(Fish. Mus., Zool. Dep., Univ. Coll., Liverpool.) Local name, "White Fluke."

In this "fluke" the scales are all small and smooth, except a few large spiny ones which form projections about the back of the head. The colour of the pigmented surface is nearly black, while the underside is opaque china-white. The flounder has only 40 to 45 ventral fin-rays, fewer than any other flat-fish, which is a useful character available for identification at all periods of life.

The flounder ranges from the North of Europe to the French coast, and is abundant round the British coast, especially in estuaries. It ascends rivers and streams into completely fresh water.

In our district the flounders come down the rivers and go to sea (" make their run") early in January in order to spawn at sea. They are said to be driven down the rivers by the frost. While at sea they are commonly caught in the trawl along with the plaice; both fish are found spawning together in February to April. The egg of the flounder measures about $0^{\circ} 95 \mathrm{~mm}$. in diameter, and usually hatches out in seven days. Flounders are also taken by stake nets on the shore and by spearing in shallow water.

At the Lancashire Sea-fish Hatchery at Piel, Mr. Andrew Scott has during the last few years hatched out large numbers of young flounder larvæ from eggs obtained from parent fish collected in November and December, and kept in tanks throughout the spawning season. It is found that it requires about ${ }_{15}$ O females and 100 males to supply about 15 millions of fertilised eggs for the hatchery, and of these about 14 millions or over 90 per cent. can be successfully hatched out.

\section{Pleuronectes cynoglossus, Linn.-Witch.}

\section{(Day's British Fishes, vol. II., p. 30, Pl. CIII.)}

(Fish. Mus., Zool. Dep., Univ. Coll., Liverpool.) Local nume, "Witch."

The Witch is distinguished from the Plaice by the more elongated oval outline of body ; and by the smaller head and mouth; by the absence of a curve on the front part of the lateral line, and by there being no red markings on the brown upper surface, while the lower is not a bright white. There are more dorsal and ventral fin-rays than in any other British flat-fish, over 100 in the dorsal and about 90 in the ventral.

This fish - the Witch or Pole-dab-is found mainly around the British Isles, extending but little to the north or south. It occurs, however, on the North American coast. It is a deep-ivater fish.

In our district fair quantities are found west of the Isle of Man and off the Calf Island. It is caught in the trawl, at all times of the year, and generally on a muddy bottom. It seems to feed chiefly on worms. There are not so many off the Lancashire and Welsh coasts, but still it does occur there, and we have taken it off St. Bees Head, Cumberland, and in the 
Menai Straits. The witch spawns from May to July. The female produces from 500,000 to 800,000 ova, which measure $1 \cdot 15$ to $1 \cdot 19 \mathrm{~mm}$. in diameter, and hatch out in about a week. We have made use of this species for some experiments in fish-hatching at the Port Erin Biological Station.

\section{Solea vulgaris, Quen.-_Sole.}

(Day's British Fishes, vol. II., p. 39, P1. CVI.)

(Fish. Mus., Zool. Dep., Univ. Coll., Liverpool.)

The true, or black, Sole and its immediate allies are distinguished from other flat-fish by the narrow, elongated, oval body, the rounded snout with the mouth a little way behind, and the curved jaws.

The true Sole ranges from Scandinavian seas to the Mediterranean, and is found around our coast generally, but is commoner in the South than in Scotland. It is a shallowwater fish. It is of frequent occurrence throughout our district, and forms one of our most important fisheries. A well-grown sole is usually from $\mathbf{I}_{5}$ to 18 inches long. The smallest ripe female we have found was $11 \frac{1}{4}$ inches, and the smallest ripe male ro inches. The Sole spawns from March to June, and produces 100,000 ova. The egg is about $1 \cdot 5 \mathrm{~mm}$. in diameter, and is distinguished from other flat-fish eggs by having many small oil globules scattered in patches over the surface of the food-yolk. The larva hatches out in about to days. We have frequently had the female sole spawning in captivity in our tanks at the Piel Hatchery, but have not yet succeeded in getting the eggs fertilised by the male.

The sole fishery of the Lancashire and Western Sea Fishery District is very valuable. The Board of Trade estimates it at $£ 28,900$ for last year, 1900. Statistics are, however, not taken at all centres where fish are landed, and the Board of Trade draws attention to the fact that this value only represents the fish when first landed direct from the fishing grounds, and points out that at a later stage of the industry, with the cost of carriage, etc., added, it is much enhanced.

The sole is captured by the use of the trawl net. The sole grounds in and adjacent to the district are numerous, and extend from the northern to the southern limits of the district. Soles are taken all the year round; in the warmer months they come near the coast, and frequent our estuaries and bays; during the colder months they go offshore into deeper water. They are occasionally taken in drag nets close to the shore, as at Port Erin, in the Isle of Man.

The spawning grounds lie at considerable distances from the shore. The sole has been taken in increasing numbers during the last few years. Bye-laws for the protection of the small sole have been in force for some years, but it is difficult, with any degree of accuracy, to attribute the increase to this, or in fact to any particular cause ; it may, however, reasonably be contended, especially as the increase appears to have been gradual, that the bye-laws have had some beneficial effect. The size of mesh formerly used in trawl nets for the capture of soles was four inches, that is, one inch from knot to knot: this was increased to six inches or one and a half inches from knot to knot, which allows large numbers of small soles to escape. There are also closed grounds in a certain part of the district, and other regulations for the protection of small soles, and lately deep-sea trawlers have used the larger mesh, whether fishing inside or outside the district. 
Solea lascaris (Risso.)-Sand sole.

(Day's British Fishes, vol. II., p. 42, Pl. CVII.)

This fish ranges from our own seas to the Mediterranean, and so is a southern form, and is most abundant on our southern coasts. It is probably found in the southern part of our area.

\section{Solea Variegata (Don.)-Thickback.}

(Day's British Fishes, vol. II., p. 43, Pl. CVIII., Fig. r.)

(Fish. Mus., Zool. Dep., Univ. Coll., Liverpool.) Local name "Lucky sole."

This is also a southern form, ranging from our own coasts to the Mediterranean, and common in Italy. Although most abundant on our southern shores, it occurs in our district, and is caught occasionally in the trawl in various parts of the Irish Sea. We never, however, see it above 7 inches in length. We have it recorded from the mouth of the Dee, and from 2 I miles W.N.W. from Morecambe Bay Lightship, April, 1894, three specimens identified by Mr. Andrew Scott.

\section{SOlea lutea (Risso.)-Solenette.}

(Day's British Fishes, vol. II., p. 44, Pl. CVIII., Fig. 2.)

(Fish. Mus., Zool. Dep., Univ. Coll., Liverpool.)

The range of this little species is also from Great Britain to the Mediterranean, but unlike the two previous kinds of sole it is exceedingly abundant in the Irish Sea. It is found all round our district, and is constantly brought up in the shrimp trawls along with the young of other flat fishes. It attains to a size of 6 inches in length, but not many are found over $4 \frac{1}{2}$ or 5 inches. As this little sole is frequently found in quantity, along with young stages of the true sole, there is some risk of confusion between the two by fishermen and others, who may not know of the existence of this little species. This was pointed out in our first "Fisheries Laboratory Report," in 1892 , and the characteristics by which the solenette could be distinguished from soles of the same size were stated.

\section{LOPHOBRANCHII.}

Gills in the form of little bunches under a large opercular fold, with a narrow opening. Scales in the form of segmental bony plates.

\section{Family Syngnathide.}

Siphonostoma typhle (Linn.)-Broad-nosed Pipe-fish.

(Day's British Fishes, vol. II., p. 257, Pl. CXLIV., Fig. 3.)

(Fish. Mus., Zool. Dep., Univ. Coll., Liverpool.)

This fish is distributed round the coasts of Europe, but is rare in most places.

Once taken at Holyhead (Eyton). We took a small specimen six inches long at Port Erin, Isle of Man, on September 3 oth, I 894.

Syngnathus acus, Linn.-Greater Pipe-fish.

(Day's British Fishes, vol. II., p. 259, Pl. CXLIV., Figs. I, 2.)

(Fish. Mus., Zool. Dep., Univ. Coll., Liverpool.) Local name, "Horned eel."

This species ranges from the northern coasts of Europe to France.

In our district Byerley records it from the Dee and the Mersey; Walker has taken it in the Dee and at Colwyn Bay; White at Menai Straits; and Moore records it, in the books of 
the Liverpool Free Public Museum, from New Brighton, at the mouth of the Mersey. We have it also from Piel in the Barrow channel, and it is occasionally taken in Port Erin bay. We get it at times in the Lancashire estuaries, and along the banks in shrimp nets.

Nerophis aequoreus (Linn.)--Snake Pipe-fish.

(Day's British Fishes, vol. II., p. 26I, P1. CXLIV., Fig. 4.)

This little species is also called the "painted sea-adder." It ranges from the northern seas down to the English Channel.

Byerley records it from the Dee, and it is also taken at the Isle of Man.

Nerophis ophidion (Linn.)-Straight-nosed Pipe-fish.

(Day's British Fishes, vol. II., p. 262, Pl. CXLIV., Fig. 5.)

Several times captured near Holyhead (Eyton).

Nerophis Lumbriciformis (Yarrell)-Worm Pipe-fish.

(Day's British Fishes, vol. Il., p. 263, Pl. CXLIV., Fig. 6.)

(Fish. Mus., Zool. Dep., Univ. Coll., Liverpool.)

Holyhead, common (Eyton); Menai Straits (White); common, under stones at lowwater of spring tides, in Port Erin bay.

Hippocampus antiquorum, Leach-Sea-horse.

(Day's Brit. Fishes, vol. 11., p. 265, Pl. CXLIV., Fig. 7.)

This is a southern species, the British Islands being about its northern limit. It ranges through the Mediterranean and Atlantic and Pacific Oceans, and is also found at Japan and Australia.

It is rare in our northern seas, but has been recorded from Dublin Bay, Belfast Bay, and other localities on the east coast of Ireland.

\section{E. PLECTOGNATHI.}

Body covered with bony plates and spines; gill opening very narrow; jaw bones united so as to bound a very small mouth; pelvic fins absent or spinulose.

\section{Family Gymnodontes.}

\section{Orthagoriscus mola (Linn.)-Sun-fish.}

(Day's British Fishes, vol. 11. p. 272, Pl. CXLVIII.)

This is a pelagic fish ranging widely through temperate and tropical regions. It visits our shores mostly in summer, and is commoner in the English Channel than further north, but has been taken in the Clyde. It is recorded in the stock-books of the Liverpool Free Public Museum as having been taken "off Southport" in 1864 .

\section{Orthagoriscus truncatus (Retz).-Oblong Sun-fish.}

This fish does not really belong to the British fauna, but it has been recorded by Day from Pembroke and Swansea, in South Wales. 


\section{Section PHYSOSTOMI.}

Air-bladder, when present, with a duct. Pelvic fins abdominal or absent. Dorsal fins with segmented, fissate, flexible rays. Gills pectinate.

There are two groups in this section, viz., the one including those important families the Herrings and the Salmonidæ, where posterior paired fins are present, and the other, including the Eels, where the fins in question are absent.

\section{A. PHYSOSTOMI ABDOMINALES.}

Pelvic fins present, and abdominal in position.

\section{Family Sternoptychide.}

Maurolicus pennantil (Walb.)-Pearl Sides.

(Day's British Fishes, vol. II., p. 49, Pl. CIX., Fig. 2.)

This species ranges from Scandinavian seas to the Mediterranean.

It has been recorded from off Flintshire, and off Dublin; from the Cheshire shore, near Bromborough Pool, in 1873 (Moore, Liverpool Free Public Museum). We also have a specimen, which is probably local.

\section{Family Salmonide.}

Salmo salar, Linn.-Salmon.

(Day's British Fishes, vol. II., p. 66, Pl. CX.)

The Salmon ranges from Arctic seas (up to $80^{\circ} \mathrm{N}$. lat.) down to the Atlantic shores of France. The annual migration to the rivers is for the purpose of spawning.

The Irish Sea receives in all about 30 salmon rivers (see above, p. 6). The salmon is occasionally taken by the trawls in our district, and sometimes in the weirs in the Menai Straits and elsewhere. We understand that it is sometimes taken in drag nets close to the shore at Port Erin in October, after dark.

\section{Salmo trutta, Linn.--Sea Trout.}

(Day's British Fishes, vol. II., p. 84, Pl. CXI., Fig. 2.) Local name, "Salmon-mort."

The salmon-trout, or sea-trout, ranges from the Baltic to the Loire, in France.

It is known locally in Lancashire as "Salmon-mort." Taken in Barrow Channel, in weirs occasionally, and elsewhere on the coast; and close to shore, in drag nets, at Port Erin in October.

\section{Salmo Fario, Linn.--Trout.}

\section{(Day's British Fishes, vol. II., p. 95, Pl. CIX., Fig. 3.)}

This fresh-water fish is occasionally found in the sea, or in estuaries. The finest trout are sometimes in brackish water, but they do not go far into the sea.

\section{Osmerus eperlanus (Linn.)--Smelt or Sparling.}

(Day's British Fishes, vol. II., p, I2I, P1. CXXI., Fig. I.) Local name, "Sparling."

The sparling ranges from the north of Europe to France, and is common round our coast, but irregular in its habits. It spends part of the year in rivers, and the remainder in the 
sea. In our district there is usually a fishery in spring in Morecambe Bay, and at Conway, with seine nets. It is also occasionally caught in trawls and shrimp nets. Fishing for smelts is prohibited from the ist of April to October 3 ist.

Byerley records many in the Mersey, in the channel between the Garston Docks and the cast iron docks. Walker says it was formerly common in the estuary of the Dee, but is now rare. Taken in Barrow Channel. We find the young, $3 \frac{1}{2}$ inches long, off Blackpool in February.

\section{Argentina sphyraena, Linn.-Hebridean Smelt.}

(Day's British Fishes, vol. II., p. ${ }_{3} 6$, PI. CXXV.)

(Fish. Mus., Zool. Dep., Univ. Coll., Liverpool.)

This fish ranges from Norway to the Mediterranean. It is rare in British seas, but has been found in the Clyde sea-area to the north of our district; and we have a specimen in the Zoological Museum at University College, Liverpool, that may have come from the Irish Sea.

\section{Family Scombresocida.}

\section{Belone vulgaris (Will.)-Garfish.}

(Day's British Fishes, vol. II., p. 146, Pl. CXXVII., Fig. I.)

(Fish. Mus., Zool. Dep., Univ. Coll., Liverpool.) Local name "Green-bone."

This fish is also known as "Green-bone" and "Sea-needle." It ranges from Iceland to the Mediterranean, but is migratory and gregarious, and so may appear in numbers in a locality, and again disappear. In our district it is fairly common at times, and is sometimes seen in the market. It is taken on mackerel lines outside Port Erin Bay.

It is taken in seine nets in Cardigan Bay (e.g., at Pwllheli), and is also caught sometimes in set nets and hose nets. In the Ulverston Channel it is taken in stake nets. Byerley records it as being on the coast of Cheshire about the mackerel season; and Walker states that it is frequently taken in the weirs at Rhos in shoals. It has been taken in the ship canal at Eastham, and in the Queen's Dock, Liverpool, in recent years.

Prof. White says "Have found them spawning in Menai Straits up to end of June. Big ones disappear to be replaced by smaller ones 15 to 16 inches long. Young ones, $2 \frac{1}{2}$ to 3 inches long, seen in September."

\section{Scombresox saurus, Walb.-Skipper.}

\section{(Day's British Fishes, vol. II., p. I51, Pl. CXXVII., Fig. 2.)}

This fish has a wide range, being found at both sides of the Atlantic, and extending down to the coasts of Africa.

In our district it is recorded from near Belfast and other points on the east coast of Ireland, and also from South Wales (Swansea Bay).

\section{Exocoetus evolans, Linn.-Flying flsh.}

This is a pelagic fish which does not belong to our fauna; but it occasionally gets carried into our seas. It has been recorded by Day from Carmarthen, in the south of Wales. Day also records that a shoal of $E$. volitans, Linn., was observed at the mouth of the Bristol Channel in August, 1876. 


\section{Family CLUPEIDÆ.}

This is the very important family to which the Herring, Sprat, Pilchard, Anchovy, and Shad belong. The members of this family are characterised by having:-No spines in the fins, no barbels, the scales very thin, one dorsal and one ventral fin, and the pelvics placed below the dorsal. The mouth is large and the teeth small. The gill openings are very large, so that the gills are much exposed. There is a well developed air-bladder opening by a duct into the stomach.

These fish live in shoals. They feed on Copepocla and other floating food which they strain out of the water. They are widely distributed in tropical and temperate seas, near coasts. They periodically come into shallower water, and even enter the estuaries; the sprat and herring are often found in brackish water, and the shads regularly go up the rivers to spawn.

The spawn of the herring is demersal, that is it is heavy and adhesive, so that it sinks in the water, and adheres to weeds, shells, and stones, at the sea-bottom. The eggs of the sprat, on the other hand, are pelagic, transparent, and buoyant. The herrings that spawn in winter (January to March) are a different race from those that spawn in summer or autumn. The winter herring frequently spawn in brackish water, while the summer herring keep further from land. The great Scottish spawning beds to the north of our district, on the Ballantrae Bank, off Ayrshire, are frequented by the winter herring, and the spawning takes place in February and March; while the herring that appears on the east coast of Scotland, and is the subject of the great fishery in July and August, is the summer herring.

\section{Engraulis encrasicholus (Linn.)-Anchovy.}

(Day's British Fishes, vol. II., p. 206, Pl. CXXXVIII, Irig. I.)

(Fish. Mus., Zool. Dep., Univ. Coll., Liverpool.)

The Anchovy ranges from the Baltic to the Mediterranean, and is usually exceedingly abundant where it occurs. It is mostly on our southern coasts that anchovy fishing is carried on, and in our district we only get occasional stragglers. Curiously enough, the fish was first obtained in our seas by Ray from the estuary of the Dee. It is recorded by Penmant, from Flintshire. Byerley records it from the Dee, Walker says, "Frequently taken in Rhos Weir," and Professor White says it is common in spring and summer in Menai Straits Two were trawled off the Liverpool bar on May 2oth, I90I, from our fisheries steamer. Last year (1900) some were obtained by Capt. Eccles.

\section{Clupea harengus, Linn.-Herring.}

(Day's British Fishes, vol. II., p. 208, Pl. CXXVIII., Fig. 2.)

\section{(Fish. Mus., Zool. Dep., Univ. Coll., Liverpool.)}

Mr. Walker writes in regard to Rhos Weir :- "The principal shoals visit North Wales in October and November, some also early in May and June. From 200 to 500 a tide were taken in the first week in June, 1891 ; about 500 on November 24,1894 , with roes about half grown ; on October Ist, 1895 , a lot of small ones, about $2 \frac{1}{2}$ inches long, were taken in the weir, and on October 17 th, about 70 full grown."

In this district most of our herring come towards the end of the year-the "winter herring"-but there may also be some in spring, the "summer herring." Like many 
migratory fishes they are sometimes irregular in their appearances; they are much more certain in Cardigan Bay, Wales, than off the Lancashire coast, where they used to be very abundant; but have not been in numbers for several years. The fishery round the Isle of Man, which used to be very important, also appears to have fallen off of late years; but it is said that the boats engaged in the "Back" herring fishery this year have had good hauls of spawning fish. On May 2oth, Igor, we trawled many young herring off Blackpool, from the "John Fell."

Herring are taken in Cardigan Bay, round Anglesey, and along the north coast of Wales in set nets, anchored nets, and stake nets. These fish are generally shot herrings.

We have known many also taken up the Mersey between Rock Ferry and Eastham.

The Morecambe boats followed the herring up, and took large quantities there a few years ago Many young herrings are destroyed with shrimp nets in the estuaries and along the banks. The Herring produces about 30,000 eggs, which hatch out in from a week to a fortnight, according to the temperature.

\section{Clupea pilchardus, Walb.-Pilchard.}

(Day's British Fishes, vol. II., p. 224, Pl. CXXXIX., Fig. I.)

This is a southern species, very abundant off the coast of France and south coast of England. It is recorded by Day from South Wales (Swansea).

\section{Clupea sprattus, Linn.-Sprat.}

(Day's British Fishes, vol. II., p. 23I, Pl. CXXXIX., Fig. 2.)

(Fish. Mus., Zool. Dep., Univ. Coll., Liverpool.)

Byerley records the Sprat as common off our coast. We have on occasions taken it commonly in the trawl. We obtained a few along with young herring off Blackpool, on May 20th, 1901. They are frequently caught in the shrimp nets in this district, and are found with the young herring in spring. The local name for sprats and young herring in the Barrow Channel is "Shads." Young herring and sprats occasionally enter Port Erin Bay in abundance ; many thousands of sprats were stranded in September, I900.

The sprat, unlike the herring, goes away from the shore to spawn, and seems to spawn any time between January and July. The pelagic egg hatches out in 3 or 4 days.

\section{Clupea finta, Cuv.-Twaite Shad.}

(Day's British Fishes, vol. II., p. 236, Pl. CXLI.)

(Fish. Mus., Zool. Dep., Univ. Coll., Liverpool.)

This fish ranges from Scandinavian seas and rivers to the Mediterranean (Nile). It enters rivers to breed. It occurs occasionally along the coast of Wales and Lancashire, and is recorded by Day from Heysham in Cumberland; "Sometimes in the Dee" (A. O. Walker); "taken in the Mersey, 20, 10, 76" (Moore, Liverpool Free Public Museum). We have obtained specimens from Formby in July, and small ones 5 inches long, in the Blackpool Closed Ground in April. Prof. White finds they go up the River Ogwen, Menai Straits, in May to spawn.

\section{Clupea Alosa, Linn.-Allis Shad.}

(Day's British Fishes, vol. II., p. 234, P1. CXL.)

(Fish. Mus., Zool. Dep., Univ. Coll., Liverpool.)

This species is rarer in our district than the Twaite Shad. Prof. White tells us that he has two specimens obtained from the Ogwen, Menai Straits. 


\section{B. PHYSOSTOMI APODES.}

Without pelvic fins.-This section includes the family of the Eels.

\section{Family Muranidae.}

ANGuilla vulgaris, Turton.-Eel.

(Day's British Fishes, vol. II., p. 24I, Pl. CXLII., fig. I.)

(Fish. Mus., Zool. Dep., Univ. Coll., Liverpool.) Local name, "Snigg."

They are abundant on our coasts, and are caught in the estuaries of our rivers, and especially near sewers, generally in eel nets and eel baskets, but are also taken by hook and line. The young eel (" eel-fare") ascend our rivers in enormous numbers early in the year, March to May. Full-grown eels descend to the sea in winter and probably spawn in deep water.

The immature transparent fish known as "Leptocephalus brevirostris" is the larva of the common eel. It is about three inches in length, and on its transformation becomes reduced to a young eel of about two inches.

\section{Conger vulgaris, Cuv.-Conger eel.}

(Day's British Fishes, vol. II., p. 250, Pl. CXLII., Figr. 2.)

(Fish. Mus., Zool. Dep., Univ. Coll., Liverpool.)

The conger eel has an extraordinarily wide range, being found not only round the shores of Europe, but also in the Indian Ocean, at Japan, and at Tasmania. It is common in the Irish Sea. Byerley records it from the Mersey and the Dee. It is caught at Hilbre Island amongst the rocks at low tide by men provided with long, curved, and pointed iron rods. It is also caught in the Rock Channel (Mersey), amongst the stones at Southport pier, and elsewhere on the Lancashire coast; also along the coasts of Wales, Isle of Man, especially where rocky, as at Port Erin. It is caught by line fishing in the Menai Straits and elsewhere, and also in trawls. It is frequently taken by the Fleetwood trawlers on the off-shore grounds. The immature stage known as "Leptocephalus morrisii" occurs in the estuaries of the Mersey and Dee, in the Wyre, and in the Barrow Channel.

\section{Order II. CHONDROSTEI.}

Internal skeleton cartilaginous ; skull and skin of body provided with membrane bones; vertebral column with a persistent notochord. Heart with a conus arteriosus; intestine with a spiral valve.

\section{Family ACIPENSERIDA.}

\section{Acipenser sturio, Linn.--Sturgeon.}

(Day's British Fishes, vol. II., p. 280, Pl. CL., fig. I, 2, 3.)

(Fish. Mus., Zool. Dep., Univ. Coll., Liverpool.)

The Sturgeon ranges in Europe from the Baltic to the Mediterranean and their rivers. In our district it is occasionally taken in the trawl and in salmon nets. Byerley records it as being sometimes captured on the North of Wirral and in the Mersey; Walker records it from 
the Dee and from the Mersey, and White from Bangor. We have it also from Barrow Channel; it has been occasionally caught in the Ribble, and it has been taken, rarely, around the Isle of Man.

\section{Division II. ELASMOBRANCHII.}

With five to seven pairs of branchial arches bounding and separating the gill clefts, which are converted into gill-bearing pouches by septa continuous with the outer skin; there is no opercular fold. The intestine has a spiral valve, and ends in a cloaca. Without membrane or cartilage bones; skin with numerous small enamelled denticles; skeleton mainly cartilaginous. Males provided with a pair of claspers. Ova few and large.

\section{Order I.* SELACHII.}

Mouth transverse and ventral; head with a snout or rostrum. Heart with a conus arteriosus. The paired fins are not archipterygial. The caudal fin is heterocercal.

\section{Sub-order I. ASTEROSPONDYLI.}

(Sharks and Dog-fishes.)

If the centra of the vertebræ are calcified it is in a radiating or stellate form. Spiracles absent or reduced. Anal fin present. Pectoral fins separated from the head.

\section{Family CARCharIIDE.}

\section{Carcharias glaucus (Linn.)-Blue Shark.}

(Day's British Fishes, vol. II., p. 289, Pl. CLII.)

This shark is widely distributed in the Atlantic and Pacific Oceans, and is frequently found in our seas during the warmer parts of the year. We also have records of their capture round the Isle of Man and off the Welsh coasts. They are common off the "Smalls," attending the schools of herring. A specimen in the Liverpool Free Public Museum, taken off the Orme's Head in September, I882, measured 5 feet ro inches in length.

Galeus vulgaris (Linn.)-Tope.

(Day's British Fishes, vol. II., p. 292, Pl. CLIII.)

(Fish. Mus., Zool. Dep., Univ. Coll., Liverpool.) Local name, "Dog-fish."

This fish has a very wide range throughout the oceans of the world. It is abundant in our seas, especially in summer. It has been frequently taken off Anglesey, and the coast of North Wales, since Pennant recorded it from Flintshire. It is sometimes taken on lines set for cod. One was caught at Piel, in Barrow Channel, in August, 1900. We have also seen it taken in the Horse Channel at the mouth of the Mersey, at the Bar, and above Liverpool in the estuary. There was a line fishery for this fish at one time off Formby, which was followed by the Southport fishermen. They are still sold in Darwen and Blackburn, in Lancashire, for food, and are known locally as "Darwen salmon."

* Extinct forms, such as the Ichthyotomi, and groups wholly unrepresented in our seas, such as the Holocephali, are omitted from this classification. 


\section{Sphyrna zygaena (Linn.)-Hammer-head.}

(= Zygaena malleus, Cuv.)

(Day's British Fishes, vol. II., p. 294., Pl. CLIV.)

This shark has a very wide range over the seas of the world, extending to Japan.

It does not properly belong to our fauna, but has been recorded by Day from South Wales (Carmarthen Bay).

\section{Mustelus vulgaris, Müller and Henle-Smooth-hound. \\ (Day's British Fishes, vol. II, p. 295, Pl. CLV.)}

This Shark ranges along the Atlantic coasts of Europe and in more southerly seas, and appears in our seas in summer. It has been recorded at various places off the east coast of Ireland in our district ; also at Colwyn Bay, by Walker, and Menai Straits, by White. It is occasionally taken around the Isle of Man.

\section{Family LAMNIDE.}

Lamna CORnubica (Gmel.)-Porbeagle.

(Day's British Fishes, vol. II., p. 297, Pl. CLVI.)

(Fish. Mus., Zool. Dep., Univ. Coll., Liverpool.) Local name, "Beaumaris Shark."

This fish, which ranges to Japan, comes from the North Atlantic into our seas in summer and autumn.

It was recorded from Beaumaris by Pennant, and is still found in that neighbourhood; also off the Irish coast opposite ; and is occasionally taken, in summer, on long lines, in the neighbourhood of the Calf, Port Erin.

\section{Alopias vulpes (Gmel.) - Thresher.}

(Day's British Fishes, vol. II., p. 300, P1. CLVII.)

This voracious shark extends in the North Atlantic from Norway to the Mediterranean.

It has been recorded from Dublin Bay and other points on the east coast of Ireland, and A. O. Walker records that it is sometimes caught in the weir at Rhos, where one 9 feet long, including the tail, was taken on July 16 th, 1893 .

\section{Selache maxima, Cuv.-Basking Shark.}

(Day's British Fishes, vol. II., p. 303, P1. CLVIII., Fig. r.)

This large shark is sometimes very abundant off the west coasts of Ireland and Scotland. "On the west coast in some years they are abundant, in others only stray fish." (Day). Recorded from Carnarvonshire and Anglesey (Pennant).

\section{Family Scyllinde.}

Scyllium canicula (Linn.)-Lesser-spotted-Dogfish.

(Day's British Fishes, vol. II., p. 309, Pl. CLIX., Fig. I.)

(Fish. Mus., Zool. Dep., Univ. Coll., Liverpool.) Local name, "Fay-dog."

This common dogfish is found round the coasts of Europe and the Mediterranean. It is frequently taken on cod lines and in trawl nets in our district Common on the Welsh coast (Eyton), Menai Straits, \&c Very common around the Isle of Man. 
Scyllium catulus, Gunn.-Nurse-hound.

(Day's British Fishes, vol. II., p. 312, P1. CLIX., Fig. 2.)

This larger spotted dogfish is found round the coasts of Europe generally, but is not so common in our seas as the last species. It is occasionally taken off Port Erin and round the Isle of Man; and Prof. White tells us he has taken one, $3 \frac{1}{2}$ feet long, this year in Carnarvon Bay.

Pristiurus melanostomus (Rafin.)-Black-mouthed Dogfish.

(Day's British Fishes, vol. II., p. 3I4, Pl. CLX., Fig. I.)

(Fish. Mus., Zool. Dep., Univ. Coll., Liverpool.)

This dogfish occurs throughout N.W. Europe and the Mediterranean, and is sometimes found in our district. We have a local specimen in the College Museum.

\section{Family SpINACide.}

Acanthias vulgaris, Risso.-_Picked Dog-fish.

(Day's British Fishes, vol. II., p. 3155, Pl. CLX., Fig. 2.)

(Fish. Mus., Zool. Dep., Univ. Coll., Liverpool.)

This common Dog-fish has a wide range in temperate seas. It occurs in great abundance all around our coasts. It is commonly taken on cod lines and in trawl nets in our district ; frequently on long lines around the Calf, Port Esin.

Echinorhinus spinosus (Cuv.)-Spinous Shark.

(Day's British Fishes, vol. II., p. 323, Pl. CLXII., Fig. 2.)

This Shark has a wide distribution, from the north of Europe to the Cape of Good Hope. It has been recorded from many points round the British coast, including one in our district. "Mr Moore has recorded one from Ireland, captured September 25th, 1882, near Skerries, about 15 miles to the north of Dublin" (Day).

\section{Sub-order II. TECTOSPONDYLI.}

(Skates and Rays).

If the centra of the vertebra are calcified, it is in the form of concentric rings. Spiracles are always present. Large pectoral fins, fused with and surrounding the sides of the head; body usually flattened dorso-ventrally. The tail fin is feeble, and there is no anal fin ; gill-slits on the ventral surface, and spiracle on the dorsal.

\section{Family RHINIDж.}

RHind sQuatina (Limn.)-Monk-fish.

(Day's British Fishes, vol. II., p. 326, P1. CLXIII.)

(Fish. Mus., Zool. Dep., Univ. Coll., Liverpool.) Local name, "Abbot."

The "Monk," or "Angel-fish," has almost a world-wide distribution, and is common off our coasts in spring and summer. It occurs not unfrequently in the trawl net in the Lancashire district. We have taken it as near Liverpool as the Rock and Horse Channels, 
and the Deposit Buoy. We have also taken it near Piel in the Barrow Channel, and off Maughold Head; and Mr. Walker records it from Rhos weir and Colwyn Bay, and Professor White from the Menai Straits. It has been frequently taken off the Isle of Man, one is recorded from Port Erin, and we have taken it also in the Ribble, and have seen in taken on the offshore grounds by the trawlers.

\section{Family TORPEDINIDE.}

TORPEDo NobILIANa, Bonap.--Torpedo.

(Day's British Fishes, vol. II., p. 331, P1. CLXIV.)

(Fish. Mus., Zool. Dep., Univ. Coll., Liverpool.)

The Electric Ray ranges from Great Britain to the Mediterranean and Madeira. It occurs occasionally in the Irish Sea. Byerley records that a specimen was taken by Hoylake fishermen in the summer of 1853 ; and we obtained one brought into Liverpool in 1892 . The latter specimen measured 3 feet 6 inches in length, and 2 feet 4 inches across the widest part. One is also recorded in the books of the Liverpool Free Public Museum as having been "caught in Meols Bay, Southport (weighing $30 \mathrm{lbs}$ ), 18/10/84;" and Professor White tells us he has obtained two within the last ten years from Carnarvon Bay.

\section{Family RaIIDE.}

Raia båtis, Linn.-Blue Skate.

(Day's British Fishes, vol. II., p. 336, Pl. CLXVI.)

(Fish. Mus., Zool. Dep., Univ. Coll., Liverpool.) Local name, "Skate."

This is "the skate" of our local fishermen, and is our largest species. It is widely distributed in N.W. Europe and the Mediterranean, and is common all round the British Islands. In our district it is abundant in all parts, and is taken both by line and by trawling all the year round on nearly all our fishing grounds. The young are frequently taken in the shrimp nets in shallow water.

\section{Raia Macrorhynchus, Raf.-Flapper Skate.}

(Day's British Fishes, vol. II., p. 338, P1. CLXVII.)

This species (?) is said to range from our seas to the Mediterranean. It has been recorded from Dublin Bay (McCoy), and our fishermen say that they occasionally trawl a skate on the off-shore grounds which seems to correspond in character with this species. We have not yet seen any specimens ourselves which could be satisfactorily distinguished from $R$. batis.

\section{RaIA ALBA, Lacép.-White Skate.}

(Day's British Fishes, vol. II., p. 339, Pl. CLXVIII.)

This species has the same distribution as $R$. batis, but is not so common. "Pennant obtained it off Carnarvonshire, and records one from the Menai Straits, taken in July, 1768 , nearly 7 feet long, and 5 feet 3 inches broad." "Yarrell also records this fish from Liverpool" (Day). Byerley records it from Liverpool, as R. marginata. Mr. E. W. L. Holt, who has been paying special attention to British Raiidæ informs us that some of the records of this species refer to $R$. batis. It is occasionally taken on long lines off Port Erin. 
Raia clavata, Linn.-Thornback Ray.

(Day's British Fishes, vol. II., p. 343, Pl. CLXXI.)

(Fish. Mus., Zool. Dep., Univ. Coll., Liverpool.) Local name, "Ray."

This is "the Ray" of our local fishermen. It is found all round the coasts of Europe and into the Mediterranean, and is abundant in our district. It is caught both by trawls and lines all round the Irish sea at all times of the year.

\section{Raia maculata, Mont.-Spotted Ray.}

(Day's British Fishes, vol. II., p. 345, Pl. CLXXII.)

(Fish. Mus., Zool. Dep., Univ. Coll., Liverpool.)

This species ranges from our coasts southwards to the Mediterranean, Byerley records it from the entrance to the Dee estuary, and we have found it off the banks round the mouth of the Mersey. We trawled it off the Liverpool Bar on May 20th, I9or. It is not uncommonly taken on long lines off Port Erin. White records it from Menai Straits. Mr. E. W. L. Holt informs us that this species is generally confused with $R$. blanda which he and $\mathrm{Mr}$. Calderwood described in $1895^{*}$. He thinks it probable that both species occur in our district, but we have not yet distinguished Raia blanda.

\section{Raia Radiata, Don.-Starry Ray.}

(Day's British Fishes, vol. II., p. 347, Pl. CLXXIII.)

This is essentially a northern species, extending from Iceland to the English Channel, or rarely to the coasts of France.

In our district it is caught occasionally by the trawl on hard ground at all times of the year, on the " off-shore" grounds. Menai Straits (White).

\section{Raia circularis, Couch.-Cuckoo Ray.}

(Day's British Fishes, vol. II., p. 348, Pl. CLXXIV.)

(Fish. Mus., Zool. Dep., Univ. Coll., Liverpool.)

This species ranges over the shores of Western Europe and into the Mediterranean, but is rare in many parts.

It is recorded from Dublin Bay and other parts of the East Coast of Ireland; Menai Straits (White), and we have found it on the Lancashire Coast, but it is not common

\section{(?) Raia miraletus, Couch-Sandy Ray.}

(Couch, Fish. Brit. Isles, vol. I., p. II2, Pl. XXVII.)

Mr. E. W. L. Holt writes to us as follows in regard to this and the last species :" $R$. circularis (of Günther and Day) includes two species. One has distinct alar ocelli. The other is almost uniform in colour, with some small white blotches. I have never got at the bottom of their synonymy, but if you call them $R$. circularis, Couch, and $R$. miraletus, Couch, folk will know what you mean. I am sure you have them both."

In regard to other species of Raia possibly present in our area, Mr. Holt adds :- "It is quite likely that you also have $R$. fullonica and $R$. microcellata, the former in deep water to the north, the latter stowed away in some isolated bay : his habitat seems to have been blown up with a bomb-shell." 


\section{RaIA oxyrhynchus, Linn.-Long-nosed Skate. \\ (Day's British Fishes, vol. II., p. 34I, Pl. CLXIX.)}

This species has been recorded from the Irish Sea, but it is a little doubtful whether the record is correct.

\section{Family Trygonide.}

Trygon pastinaca, Cuv.--Sting Ray.

(Day's British Fishes, vol. II., p. 350, Pl. CLXXV.)

The sting ray ranges throughout the North Atlantic and Mediterranean, and has also been found in the North Pacific. It is not uncommon on the south and east coasts of England. It has been recorded from sereral points on the east coast of Ireland, and Byerley states, "Taken a few times [near Liverpool], but rare-one caught near Hilbre Island, 1851." Mr. Clubb informs us that the stock-books of the Liverpool Free Public Museum record specimens as having been taken in the Rock Channel in 1868 and 1869 , and near the Bell Buoy in 1877 .

\section{Class CYCLOSTOMATA.}

Without true jaws, and without paired limbs, mouth suctorial and provided with horny teeth, with sac-like gill pouches or gill slits. Nasal cavity unpaired, median. Alimentary canal straight. No scales; skin glandular. Vertebral column with persistent notochord. Optic nerves form no chiasma.

\section{Order I. HYPEROARTIA.}

Roof of mouth imperforate.

\section{Family Petromyzontide.}

This includes the Lampreys. The ear has two semicircular canals. The gill pouches open separately to the exterior. The nasal sac does not communicate with the mouth cavity. There is a well developed dorsal fin.

\section{Petromyzon marinus, Linn.-Sea-Lamprey.}

(Day's British Fishes, vol. II., p. $35^{6}$, Pl. CLXXVIII.)

This species has a wide distribution through the seas of Europe, and extends down the West African Coast.

Lampreys have been recorded from Dublin Bay, but are apparently rare in the Irish Sea. They have been obtained off the Ribble on the Lancashire Coast, in the streams between Warrington and the Mersey, at the mouth of the Mersey and in the Dee.

\section{Petromyzon fluviatilis, Linn.-Lampern.}

(Day's British Fishes, vol. II., p. 359, Pl. CLXXIX., Fig. I.)

(Fish. Mus., Zool. Dep., Univ. Coll., Liverpool.) Local name, "Silver eel."

This lamprey has an extensive range in both salt and fresh water along the coasts of Europe, North America and Japan. In our district we have found it at Piel, in the Ulverston 
Channel, and off Morecambe. There are also the following records:-River Dee, not uncommon (Byerley); in the Alt, scarce (Parker); another species has also been seen in the Alt (? P planeri); they were gregarious 12 or 14 together in gravelly shoals (Byerley); in the Dee (A. O. Walker), and in the Menai Straits (White).

\section{Order 2. HYPEROTRETA.}

Roof of mouth perforated by nasal sac.

\section{Family Myxinide.}

This group of marine parasitic fish-like animals are the lowest living true vertebrates. The ear has only one semicircular canal. The external openings of the gill pouches are continued into long tubes, which have one posterior opening on each side of the body. The nasal sac communicates with the mouth cavity. There is no dorsal fin.

\section{Myxine glutinosa, Linn.-Hag.}

(Day's British Fishes, vol. II., p. 364, P1. CLXXIX., Fig. 3.)

The "Glutinous Hag" ranges over the north-west coasts of Europe and the east coast of N. America. It is mainly a northern fish, and is commoner in Scandinavian and Scottish waters than in the Irish Sea.

It has been recorded from Dalkey, Co. of Dublin, by Wright, and from Swansea by Day. We have not yet found it in our area. 


\section{THE CONSTITUTION AND WORK OF THE LANCASHIRE AND WESTERN SEA FISHERIES COMMITTEE.}

\section{r. Constitution and Objects.}

The remarks in this chapter refer principally to the work of the Lancashire Sea Fisheries Committee, as it was not until last year (1900) that the two Fisheries Committees, the Lancashire and the Western, were amalgamated, and previously to that our work was entirely with the Lancashire Committee.

The Lancashire Sea Fisheries Committee was constituted in 1890 , and consisted of the following 64 members :-

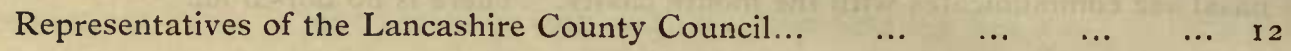

One representative each from the Cheshire and Cumberland County Councils 2

Representatives of the County Boroughs of Lancashire and Cheshire ... $\quad \ldots \quad$ I7

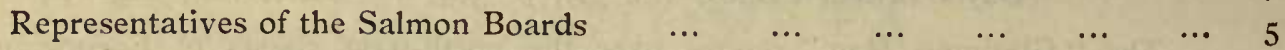

Members appointed by the Board of Trade $\ldots \quad$...

The object of Sea Fisheries Committees is to protect and improve the sea fisheries, in order that the fish supply to the public may be increased, or at any rate maintained,* and also to protect and assist the means of livelihood of the fishermen.

Before the constitution of Sea Fisheries Committees, fishermen fished when and where they wished, used any kind of net, or size of mesh, and captured fish regardless of size or condition. Laws were in force regulating the taking of oysters, game, and salmon, but none to prevent the immense destruction of immature and undersized sea-fish which was daily taking place, or to prevent the use of instruments and methods of fishing which, in time, would destroy the fisheries.

Amongst the first to call for legislation were the fishermen of Lancashire, and the first Sea Fisheries Committee to be constituted was that of Lancashire. The prime mover in effecting this was Mr. John Fell, of Ulverston, the present chairman of the Lancashire and Western Sea Fisheries Committee, and who, prior to the recent amalgamation, had been chairman of the Lancashire Sea Fisheries Committee from its foundation.

The powers given to sea fisheries committees are chiefly :-

For restricting or prohibiting, either absolutely or subject to such regulations as may be provided by the bye-laws, any method of fishing for sea-fish, or the use of any instrument of fishing for sea-fish.

For determining the size of mesh, form, and dimensions of any instrument of fishing for sea-fish.

For prohibiting or regulating the deposit or discharge of any solid or liquid substance detrimental to sea-fish or sea-fishing.

For fixing the size and condition at which shell-fish, crabs, and lobsters may not be removed from a fishery.

* To give some idea of the importance of Sea Fisheries in the food supply of this country, the Board of Trade returns for 1900 show that the value of fish first landed direct from the fishing grounds, including shell-fish, was $£ 9,678,000$. Of course, by the time it reached the consumer, that value would be very much increased, 


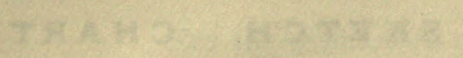

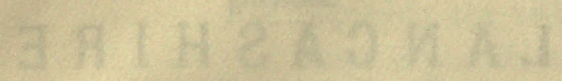

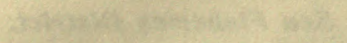

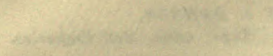
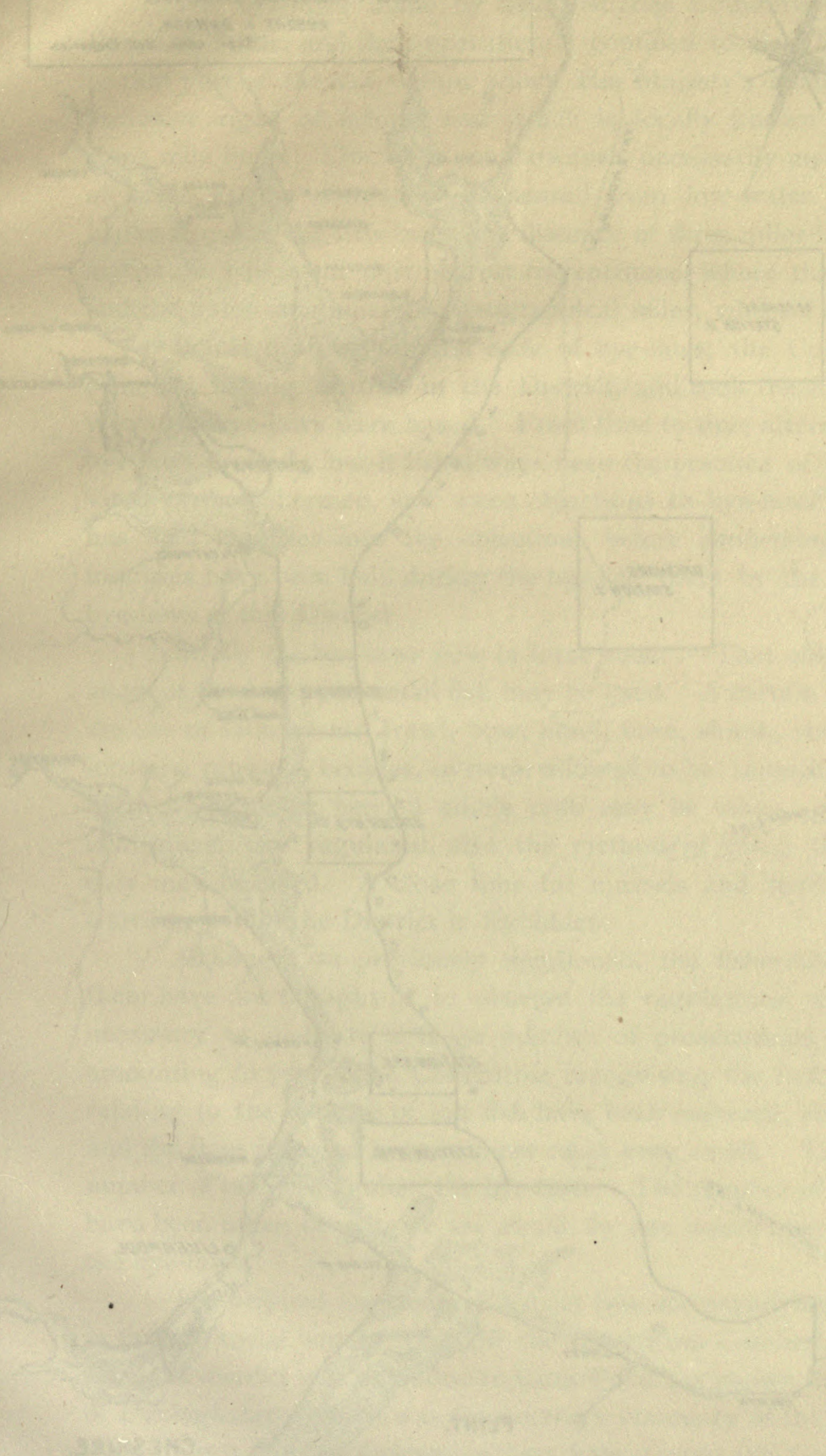

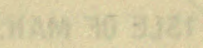




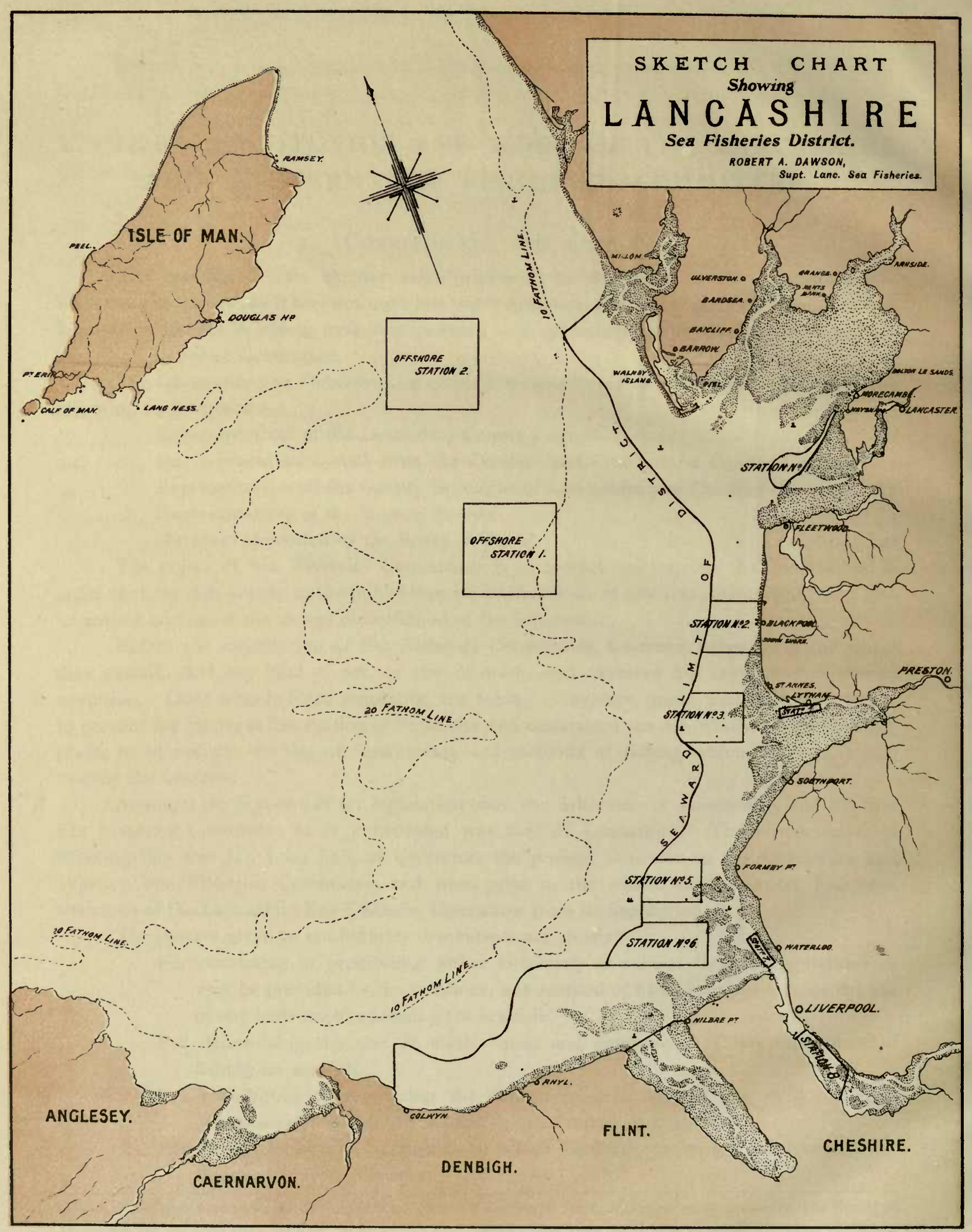

Jas Miller: Litho.Prescma 
For the protection of shell-fish laid down for breeding purposes.

For requiring the re-deposit in specified localities of any shell-fish, the removal of which is prohibited by or in pursuance of any Act of Parliament.

The bye-laws made by Sea Fisheries Committees are subject to confirmation by the Board of Trade, and their operation is confined to Sea Fisheries Districts, which are limited to that part of the sea within which His Majesty's subjects have by International Law the exclusive right of fishing, and which is locally known as the territorial waters within the three mile limit. This does not, however, necessarily mean only three miles from the coast in all cases, as the distance is measured from low-water mark of the dependent islands and banks ; and as regards bays, the distance of three miles is measured from a straight line drawn across the bay in the part nearest the entrance, where the width does not exceed ten miles; and the miles mentioned are geographical miles, whereof sixty make a degree of latitude.

Before drafting the first code of bye-laws, the Committee held public inquiries at the principal fishing centres in the District, and took the views of the fishermen, and upon these views the bye-laws were based. From time to time alterations have been made, or additional bye-laws drafted; but it has always been the practice of the Committee to first ascertain the views of the fishermen, and when objections to bye-laws have been made, the Board of Trade has held inquiries into the objections before confirming the bye-laws. In all, six public inquiries have been held during the last ten years by the Board of Trade with regard to the bye-laws of this District.

Briefly the bye-laws now in force enact:-That only nets which have meshes which will allow of the escape of small fish may be used. A certain area off Blackpool is closed against the use of seine, draft, trawl, bow, hand, hose, shank, stake, or otter nets. The size of crabs, lobsters, mussels, cockles, oysters, allowed to be removed from a fishery is regulated. No berried lobster or berried edible crab may be taken. The forms and sizes of nets and other instruments are regulated, also the method of using them, and the places and times where they may be used. A close time for mussels and sparling is enforced. And, finally, steam trawling within the District is forbidden.

Although, as previously mentioned, the fishermen asked for legislation, a number of them have not thought fit to observe the regulations, and unfortunately it has been found necessary to institute a large number of prosecutions, the number up to the end of Igor amounting to 770 . The Committee recognising the fact that for many years no regulations relating to the capture of sea fish have been enforced, have seldom asked for heavy penalties, and the fines imposed have in most cases been small. This may perhaps account for the large number of offences against the bye-laws. The number of cases, however, in which proceedings have been taken do not, we are afraid, by any means represent the number of infringements of the bye-laws.

The original Lancashire District (see accompanying sketch chart) included the fisheries in the territorial waters lying off the coast from Cumberland to Hilbre Island in Cheshire. In 1894 the district was extended to Rhos Point (as shown in sketch chart), the western extremity of Denbighshire, which was the northern boundary of the Western Sea Fisheries District.

Since the amalgamation last year (1900) the Committee has been enlarged, and the number of members is now as follows :-

Representatives of the following counties :-Lancashire 8, Cheshire 2, Flintshire I, Denbighshire 1, Carnarvonshire 2, Anglesey 2, Merionethshire 2, and Cardiganshire 2. 
Liverpool and Manchester have each two representatives, and the following boroughs each one :-Barrow, Birkenhead, Blackburn, Bolton, Bootle, Burnley, Bury, Chester, Oldham, Preston, Rochdale, St. Helens, Salford, Stockport, Wigan, and Southport.

The following Boards of Conservators of Salmon Districts have each one representive :-Kent, Lune, Ribble, Dee, Elwy and Clwyd, Conway, Seiont, Dwyfach, Dovey, Ayron, and Teify.

Finally, 29 members are appointed by the Board of Trade, making 80 of a Committee in all.

The present joint district extends from a line drawn true south-west from Haverigg Point, in Cumberland, round the sea coasts of Lancashire, Cheshire, Flintshire, Denbighshire, Carnarvonshire, Anglesey, Merionethshire and Cardiganshire, to a line drawn true north-west from Kemmaes Head, in the County of Pembroke - a coast line of $38_{3}$ nautical miles, or 44 I statute miles : that is, measuring round the larger bays, and some of the estuaries, but not up the rivers, nor Barrow Channel, nor the Menai Straits from Beaumaris to Carnarvon. The area, including the channels and rivers, out to the three-mile limit, is 1,300 square nautical miles, or $\mathrm{r}, 498$ square statute miles.

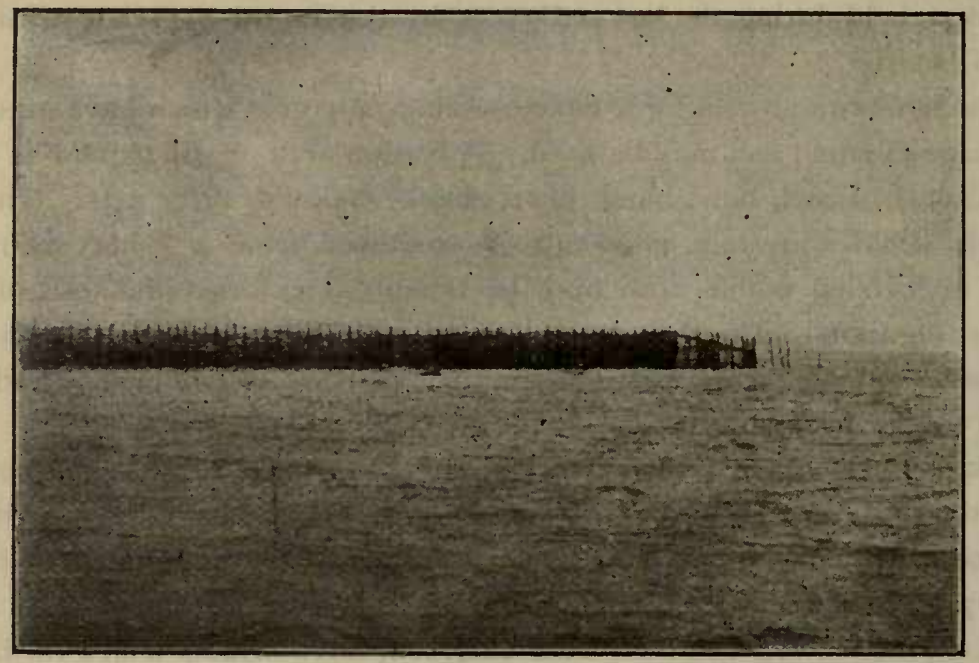

Fig ro. - A Hedge-Baulk.

\section{The Fishermen and Fisheries of the District.}

The number of fishing boats and fishermen fishing from the ports in the Lancashire and Western Sea Fisheries District is as follows : -48 steam trawlers, 98 first-class sailing trawlers, $53^{2}$ second-class sailing trawlers, prawn boats, and shrimping boats, 470 thircl-class boats. The number of fishermen who fish from boats is $2,84 \mathrm{I}$, and of shore fishermen 746 . The shore fishermen include cart and push-net shrimpers, shellfish gatherers, stake-net fishermen, crab, lobster, and shore-net fishermen. The above list does not include boys, girls, and older persons employed in shrimp picking, nor any persons employed in connection with the fishing industries ashore, of which there is a large number, nor are the trawlers or other vessels included which come from a distance, as for instance, the Brixham trawlers now fishing in Cardigan Bay. 
Nearly every description of sea fishing is carried on within this District, including fish trawling; line fishing in all its branches; drift net, trammel net and draw net fishing; set nets and stake nets in many different forms are also used; weirs and hedge baulks are found in places.

Besides the above, there is a very large shrimping industry, which is carried on by the use of shrimp trawls, shrimp shank nets, hose nets, and push nets.

Lobsters, crabs, and prawns are taken in many localities, and there is a very large area of shell-fish beds-mussels, cockles, and oysters.

Twenty-three salmon rivers flow into the District, but the work of the Sea Fisheries Committee in no way interferes or in any way clashes with the work of Salmon Boards, the only connection between the two being that in cases where the Sea Fisheries District overlaps that under the jurisdiction of a Salmon Board, the Fishery Officers hold appointments as Salmon Bailiffs, and in their ordinary course of

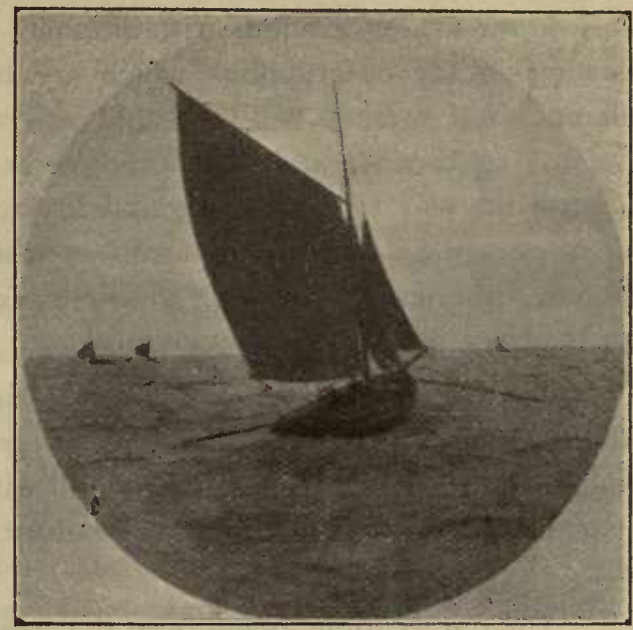

Fig i I.-Boat aorking four Shank nets. duty assist the Salmon Boards by reporting to them any offences against the salmon bye-laws that come under their notice. This has been found of material advantage in the preservation of salmon, especially in the estuaries, and has done much to put a stop to the taking of salmon by the use of stake nets.

\section{Administrative Work.}

The administrative staff consists of a Superintenclent, I 2 fisheries officers, and the crew of the steamer, which is composed of a captain and ro men. In addition to these there are at present 7 assistant fishery officers, who receive a small annual retaining fee. Some of the salmon bailiffs and a few others also hold certificates as honorary fishery officers. The Scientific Department consists of an Honorary Director of scientific work, and two scientific Assistants-Mr. Andrew Scott, who has charge of the Sea-fish Hatchery and Marine Laboratory at Piel, and Mr. James Johnstone, B.Sc., at the Sea-Fisheries Laboratory in University College, Liverpool.

The District is split up into four divisions. The first extends from Haverigg Point, in Cumberland, to the River Ribble ; the second from the River Ribble to Rhos Point in Colwyn Bay ; the third from Rhos Point round Anglesey to the south-western extremity of Carnarvonshire; and the fourth from the south-western extremity of Carnarvonshire to Kemmaes Head in Pembrokeshire. These divisions include, besides the territorial sea area, a large portion of the rivers, bays, channels, and straits found along the coast.

In each of the divisions there are stationed three fisliery officers (one head fishery officer and two under ones), with a sailing cutter and a boarding boat. Their primary duties are to enforce the bye-laws within their particular divisions, but they are also required to do duty on the steamer, or in other divisions, when called upon by the superintendent. In order to carry 
out their work they cruise about on the fishing grounds, boarding the clifferent fishing vesseis at sea, and measuring the nets in use, as well as in harbour. They have frequently to visit the shell-fish beds, examining the fish taken and the instruments used; also to examine the stake nets set along the coast. In cases where infringements of the bye-laws are observed the illegal nets or instruments are seized. Another part of the fishery officers' duty is to make hauls on the fishing grounds with different kinds of fish and shrimp nets for the purpose of assisting in the observations which are being made in order to discover what size of fish different sized meshes will take, and where the young fish congregate. They also collect samples, specimens, and tow-nettings for the work of the Scientific Department. These samples are sent to be investigated in the Laboratories. The fishery officers have to keep cliaries of work clone, fill up forms of results of hauls, make reports of the results of the different fisheries within their divisions, report offences against the bye-laws, and attend and give evidence in cases of prosecutions.

The work done by the steamer is similar to that done by the fishery officers on their sailing cutters, with the addition of surprise visits, which have to be made to the fishing. grounds in all parts of the district; and with so long a coast line, this entails a great amount of steaming, and, owing to the wild nature of some parts of the coast, is at times dangerous work.

The observations taken from the steamer as to results of hauls with different nets, and of various meshes, are also on a larger scale-the offshore grounds, Cardigan Bay and other distant fishing grounds, being frequently visited for this purpose. As an example of the experimental and observational work carried on by the steamer, we give here the results of a series of experimental hauls, which we made in 1894 , with a trawl provided with two nets, a finer outside a coarser, so as to show how under-sized sea-fish can be saved by the use of a larger size of mesh, which allows of their escape.

In these trials a trawl-net of 7 -inch mesh was used. This had a second net outside, of $4 \frac{1}{2}$-inch mesh, laced round the cod end in such a manner that no fish could enter the outer finer net without having first passed through the meshes of the trawl-net of 7 -inch mesh.

Ist Haul-Queen's Channel, Mersey, August 23rd, I894:-

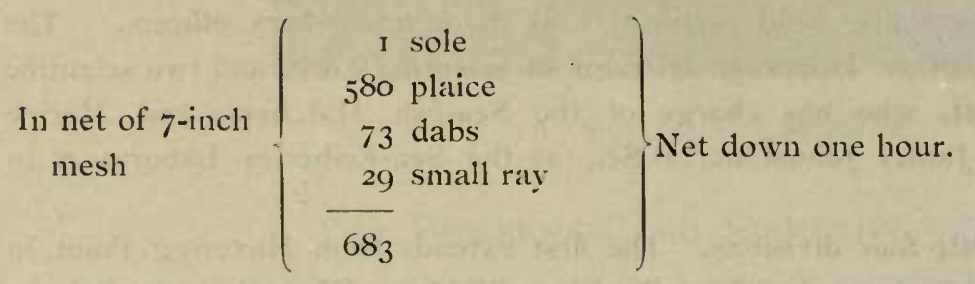

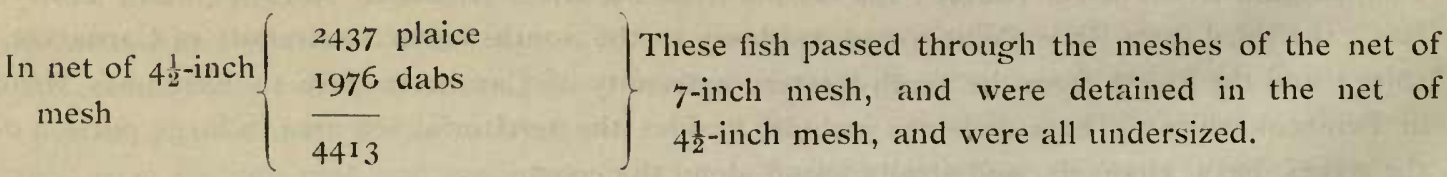

The result of this haul shows that under ordinary circumstances in this one short drag 4,4I3 small fish would have escaped through the meshes of a trawl-net of 7 -inch mesh, but would have been retained in a trawl-net of $42^{1}$-inch mesh. 
2nd Haul-Bog-hole, Southport, June 29th, I894 :-

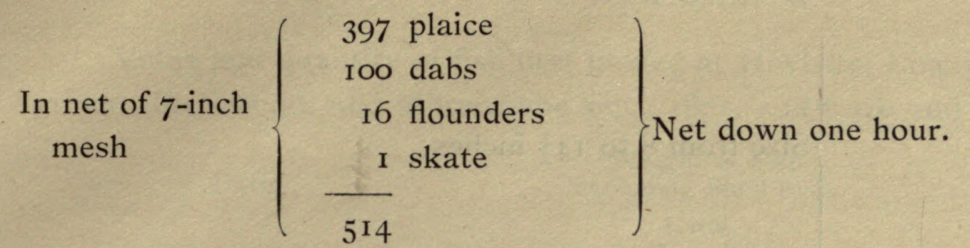

In net of $4 \frac{1}{2}$-inch $\left\{\begin{array}{l}47 \text { Io plaice } \\ \text { mesh }\end{array}\left\{\begin{array}{l}\text { Of } 5 \text { dabs } \\ \frac{35}{7260}\end{array} \quad \begin{array}{l}\text { young ray } \\ \text { the trawl-net having } 7 \text {-inch mesh, and were retained } \\ \text { in net of } 4 \frac{1}{2} \text {-inch mesh, all were undersized ; in } \\ \text { fact, none of them were } \frac{1}{4} 1 \mathrm{~b} \text {. in weight. }\end{array}\right.\right.$

Again we see the great saving of young fish life by use of a larger size of mesh. A number of independent witnesses were present when the haul was made.

3rd Haul-Bog-hole, Southport, July 26th, 1894:--

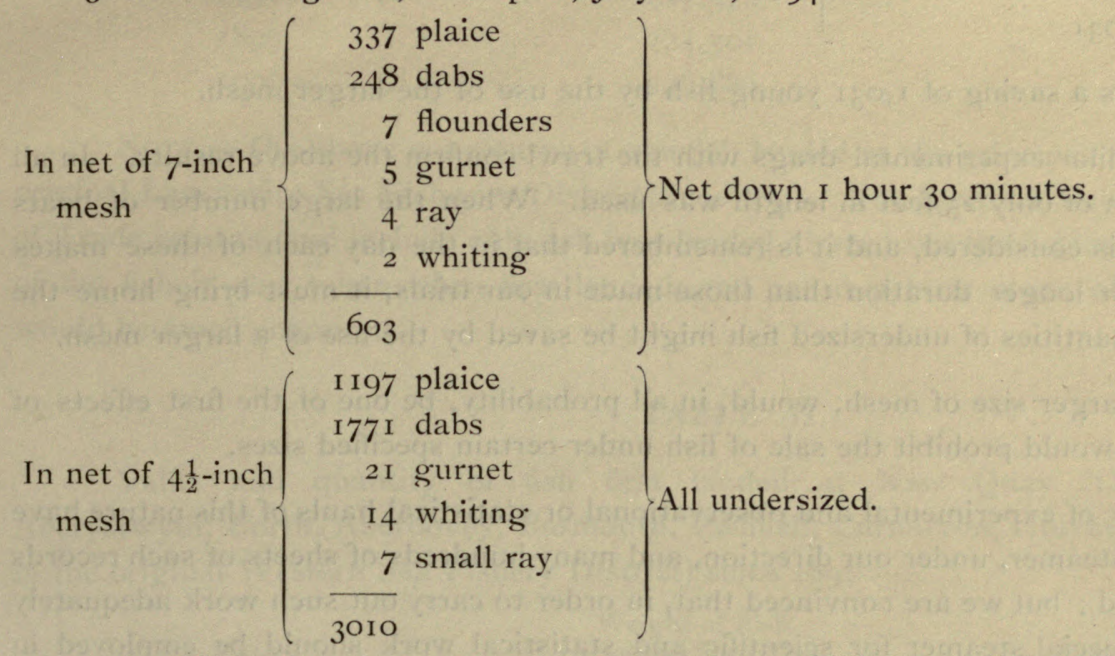

In this haul we have 3 , oro small food fishes riddled out of the net of larger mesh.

4th Haul-Horse Channel, Mersey, August 9th, 1894 :-

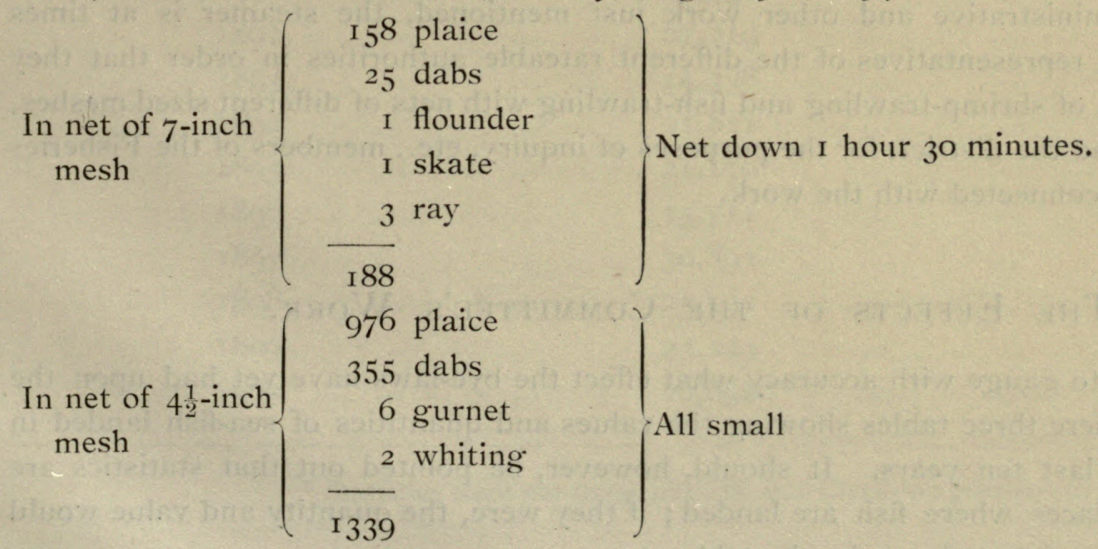

Here we have I, 339 undersized fish passing through the net of larger mesh, and which, under ordinary circumstances, would have escaped. Members of the Liverpool City Council and Lancashire Sea Fisheries Committee witnessed this haul. 
$5^{\text {th }}$ Haul-July igth, 1894 . Net down I hour 30 minutes :-

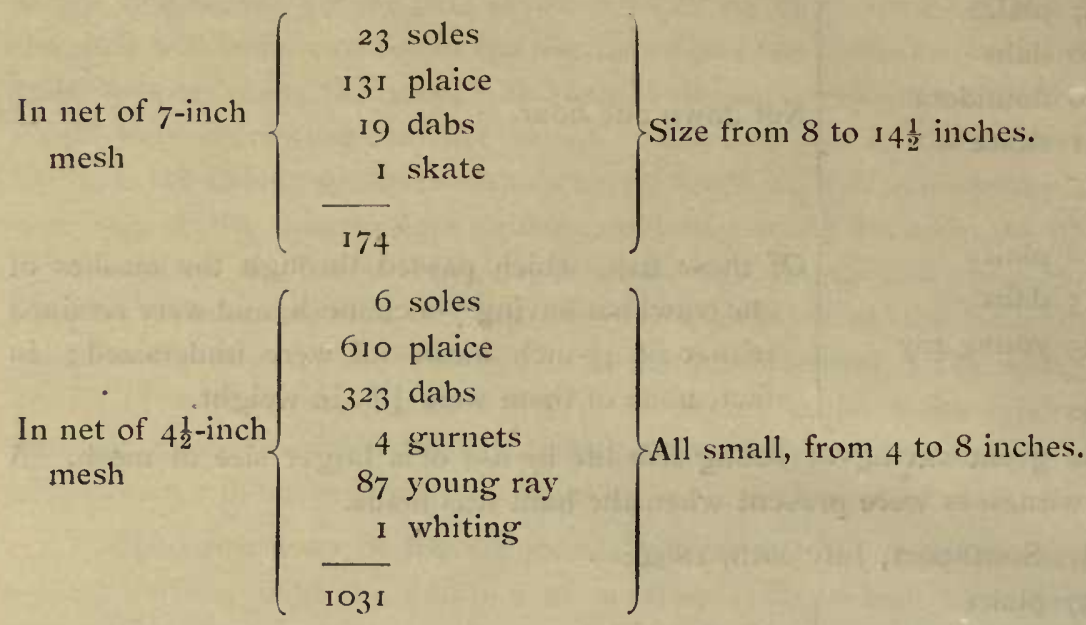

This haul shows a saving of $\mathrm{I}, \mathrm{O}_{3} \mathrm{I}$ young fish by the use of the larger mesh.

Many other similar experimental drags with the trawl confirm the above results. In all the trials a trawl beam of only 25 feet in length was used. When the large number of boats employed in trawling is considered, and it is remembered that in the day each of these makes several hauls of much longer duration than those made in our trials, it must bring home the fact that enormous quantities of undersized fish might be saved by the use of a larger mesh.

Such use of a larger size of mesh, would, in all probability, be one of the first effects of any legislation which would prohibit the sale of fish under certain specified sizes.

A large number of experimental and observational or statistical hatls of this nature have been made, from the steamer, under our direction, and many hundreds of sheets of such records have been accumulated; but we are convinced that, in order to carry out such work adequately and satisfactorily, a special steamer for scientific and statistical work should be employed in our area of the Irish Sea.*

Besides the administrative and other work just mentioned, the steamer is at times employed in taking out representatives of the different rateable authorities in order that they may witness the results of shrimp-trawling and fish-trawling with nets of different sized meshes, and also in taking round the district, for the purposes of inquiry, etc., members of the Fisheries Committee and others connected with the work.

\section{The Effects of the Committee's Work.}

It is impossible to gauge with accuracy what effect the bye-laws have yet had upon the fisheries, but we give here three tables showing the values and quantities of sea-fish landed in the district during the last ten years. It should, however, be pointed out that statistics are not taken at all the places where fish are landed; if they were, the quantity and value would necessarily be in excess of that shown by the tables.

* See the scheme suggested in the Lancashire Sea Fisheries Laboratory Report for 1900, p. 24. 
TABLE I.

Value and quantity of fish first landed at Hoylake, Liverpool, Southport and Marshside, Lytham, Fleetwood, and Morecambe since 1891, and Cark and Ulverston* since 1895 :-

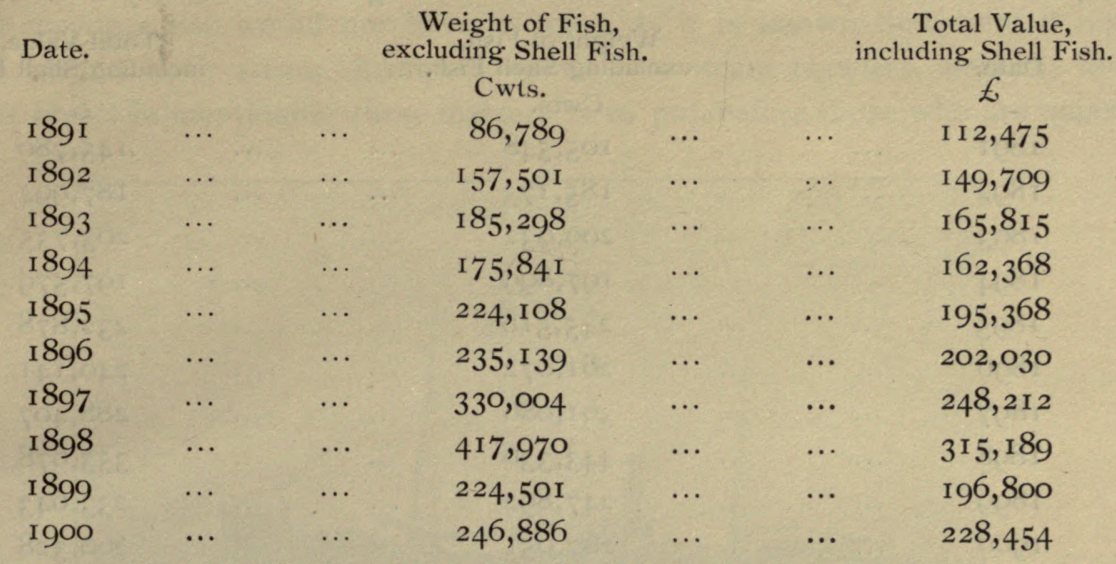

Note. - The above are returns of the fish landed at the principal fishing stations in the original Lancashire Sea Fisheries District since I891. The figures are compiled from the Board of Trade returns, and include only fish first landed direct from the fishing grounds. The value of the fish is also taken when first landed, and not at a later stage of the industry when it would be much enhanced.

TABLE II.

Value and quantity of fish first landed at New Quay (Cardigan), Aberayron, Aberystwyth, Borth, Aberdovey, Barmouth, Pwllheli, Carnarvon, Holyhead, and Bangor (ports in the original Western Sea Fishery District) since I891 :-

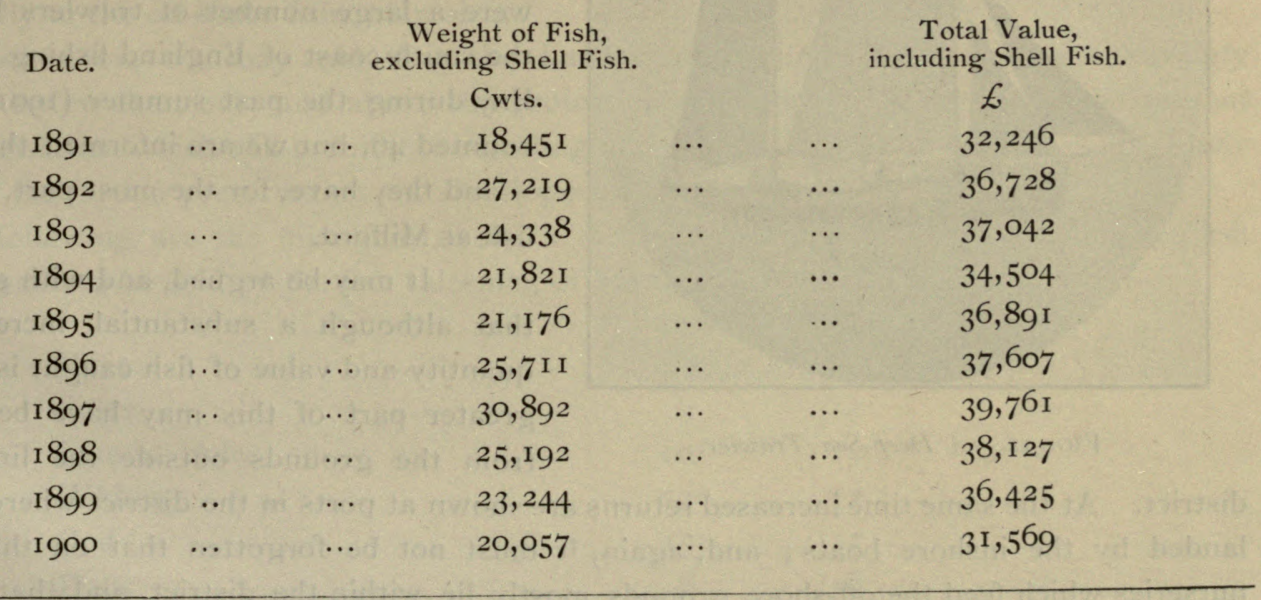

* Statistics were not taken at Cark and Ulverston previous to 1895 . 
TABLE III.

Value of fish landed direct from the fishing grounds at the various ports in the Lancashire and Western Sea Fisheries District, including Rhyl, which is omitted from the two first tables, as it was not included in either of the two original Sea Fishery Districts :-

\begin{tabular}{|c|c|c|c|c|c|c|}
\hline Date. & & & $\begin{array}{l}\text { Weight of Fish, } \\
\text { excluding Shell Fish. } \\
\text { Cwts. }\end{array}$ & & & $\begin{array}{c}\text { Total Value, } \\
\text { including Shell Fish. } \\
£\end{array}$ \\
\hline 1891 & $\ldots$ & $\ldots$ & $105,54^{8}$ & $\ldots$ & ... & 145,780 \\
\hline 1892 & $\ldots$ & $\ldots$ & I 85,173 & $\ldots$ & $\ldots$ & I 87,994 \\
\hline r893 & ... & $\ldots$ & $209,93^{2}$ & $\ldots$ & $\cdots$ & 203,735 \\
\hline 1894 & $\ldots$ & $\ldots$ & 197,899 & $\ldots$ & $\ldots$ & 197,579 \\
\hline I 895 & .. & $\ldots$ & 245,518 & $\ldots$ & $\ldots$ & 232,878 \\
\hline I 896 & $\ldots$ & $\ldots$ & 261,072 & $\ldots$ & ... & $240, \mathrm{I} 4 \mathrm{I}$ \\
\hline 1897 & $\ldots$ & $\ldots$ & $3^{6} \mathrm{I}, 086$ & $\ldots$ & $\ldots$ & 288,407 \\
\hline 1898 & $\ldots$ & $\ldots$ & $443,33^{6}$ & $\ldots$ & $\ldots$ & 353,678 \\
\hline I 899 & $\ldots$ & $\ldots$ & 247,892 & $\ldots$ & $\ldots$ & 233,643 \\
\hline 1900 & & $\ldots$ & 267,051 & $\ldots$ & $\ldots$ & 260,328 \\
\hline
\end{tabular}

It will be seen that in the original Lancashire Sea Fisheries District the value of fish landed in 1900 shows an increase of $£_{31}, 654$ over that of the preceding year, 1899 , and a decrease in the original Western Sea Fisheries District of $£_{4}, 85^{6}$ for the same period ; but this does not necessarily indicate a decrease in the quantity of fish taken from the Welsh fishing

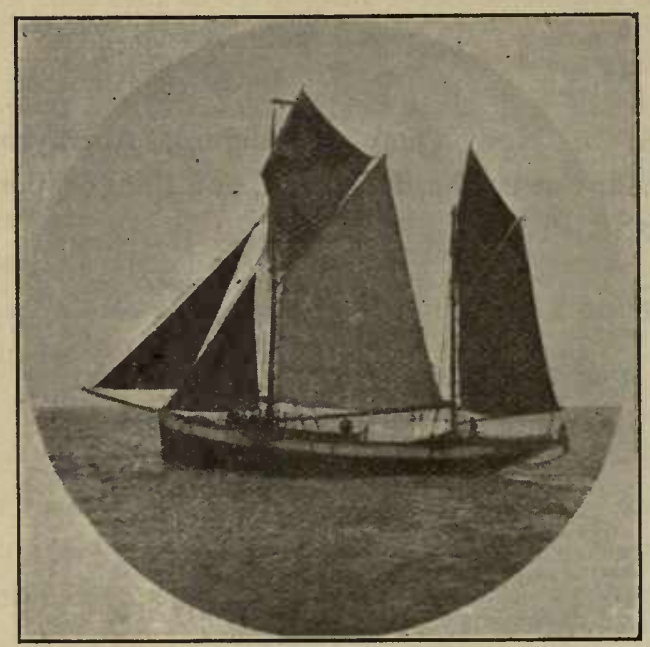

Fig. I2. - A Deep-Sea Trawler. grounds, as owing to many of the sailing trawlers now being fitted with ice chests, the fish, instead of being landed at Carnarvon, Pwllheli, \&c., and forwarded to market by rail as formerly, is frequently taken to other ports by the trawlers themselves. For instance, there were a large number of trawlers hailing from the south coast of England fishing in Cardigan Bay during the past summer (1901), - we have counted 46 , but we are informed there were 60 -and they have, for the most part, landed their fish at Milford.

It may be argued, and with good reason, that although a substantial increase in the quantity and value of fish caught is shown, the greater part of this may have been obtained from the grounds outside the limits of the district. At the same time increased returns are shown at ports in the district where fish is only landed by the inshore boats; and, again, it must not be forgotten that on this coast the nurseries which feed the off-shore grounds mostly lie within the district, and that if they are not preserved the outside grounds cannot continue to produce the same results.

It is probable that the value of bye-laws or fishery regulations cannot be fairly judged by statements of increased or decreased takes alone, as the question arises, what would be the state of the fisheries at the present time had there been no bye-laws? For instance, it seems reasonable to surmise, with regard to the Lancashire and Western Sea Fisheries District, that 
in these days of ever-increasing catching power, steam fishing vessels and otter trawls, had it not been for the bye-laws, the nurseries and grounds lying near the coast would have been sivept clean again and again, until they were practically fished out, not only to the detriment of these grounds themselves, but also, as we have shown, of the grounds lying further seawards. The shrimper also would not have escaped, as it is known that were it not for the bye-laws we should have steam shrimpers, as well as steam trawlers, working the inshore waters. Our object in mentioning these matters is to put before those who are opposed to all

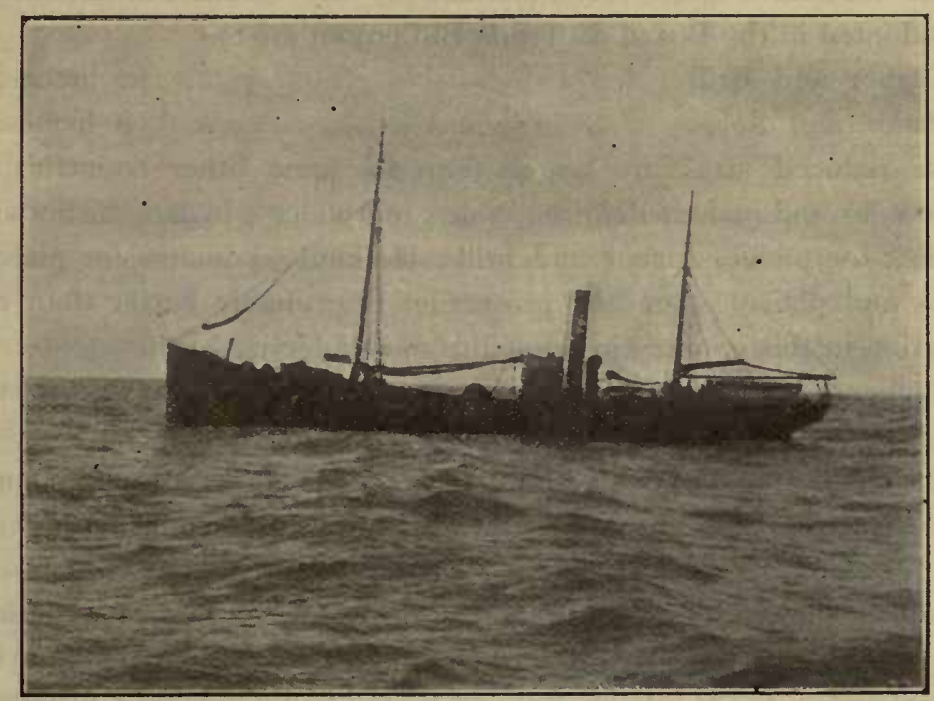

Fig 13.- 4 Steam Traziler.

regulations or fishery protection, the view that, if the bye-laws were abolished, however much it might benefit a few for the moment, it would directly bring disaster to the inshore fisherman, and eventually to the off-shore fisherman also.

In conclusion, we may add that the Lancashire Committee have always strongly supported the view that, over and above the protection given to the fisheries by the present bye-laws, legislation which will prohibit the landing and sale of undersized sea-fish is absolutely essential for the further preservation and development of our Sea Fisheries.

The following are the minimum sizes, in inches in extreme length, of certain sea fish as recommended to be sold by the fish salesmen of Liverpool, Manchester, Blackburn :-

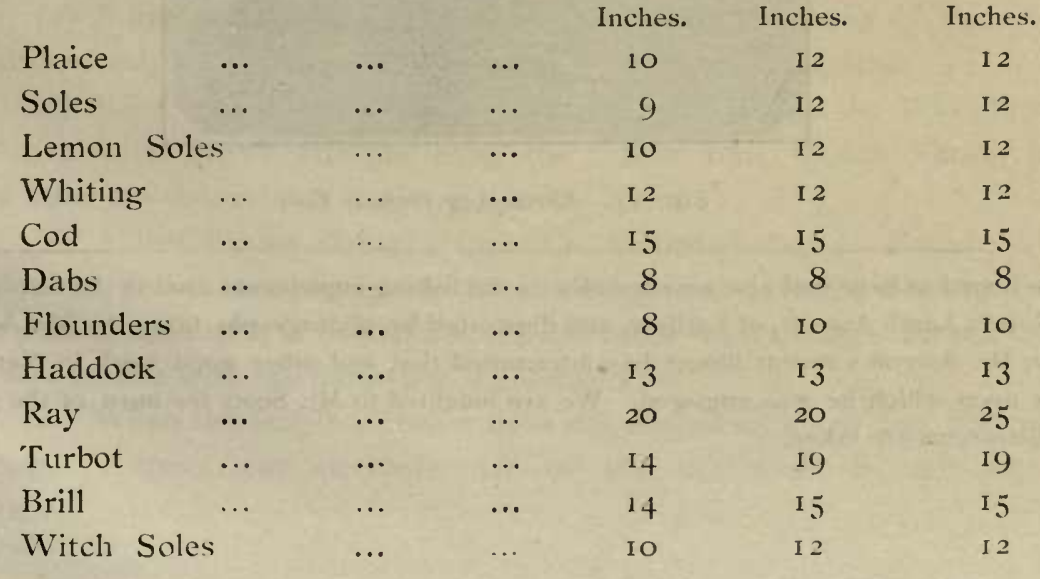


The minimum sizes as recommended by the National Sea Fisheries Protection Association are :--

\begin{tabular}{|c|c|c|c|c|c|c|c|}
\hline Brill & & under & 12 & inches & in & extreme & length \\
\hline Lemor & Soles & ,", & II & , & , & , & ", \\
\hline Plaice & & , & 10 & ," & " & " & ", \\
\hline Soles & & ," & IO & , & , & ," & ," \\
\hline Turbo & & , , & I 2 & ," & ," & ," & , \\
\hline
\end{tabular}

Finally, the minimum sizes recommended by the recent Parliamentary Sea-fisheries Committee, and adopted in the Board of Trade Bill (1900) are :-

$\begin{array}{lllllr}\text { Turbot and Brill } & \ldots & & \ldots & \ldots & \text { Io inches. } \\ \text { Plaice and Soles } & \ldots & \ldots & \ldots & \ldots & 8 \text { inches. }\end{array}$

Even these reduced sizes are larger than in some other countries, France having only $5 \frac{1}{2}$ inches for soles and plaice; Belgium, soles and plaice 7 inches, turbot and brill 9 inches; Denmark $9 \frac{3}{4}$ inches for plaice, turbot and brill ; Holland $6 \frac{3}{4}$ inches for plaice, and Germany 8 inches for soles and plaice. But any protection is probably better than none, and as yet there is no legislation in this country in regard to our undersized fish.

We now append as giving further information in regard to the working of our District* :-

I. A copy of the Draft Bye-laws adopted for the Lancashire and Western SeaFisheries Committee, and now awaiting the confirmation of the Board of Trade.

II. Tables showing the results of some of our series of experimental hauls as samples of the scientific and statistical work carried on by our fisheries steamer, the "John Fell," and by the bailiff's sailing cutters.

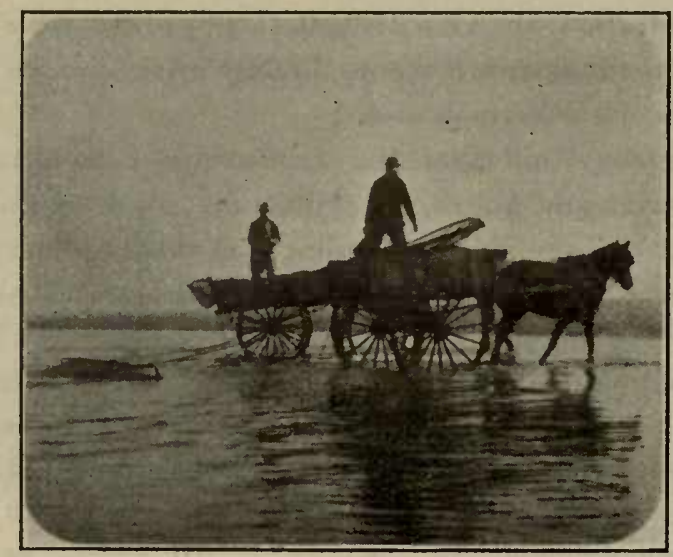

FIG. 14.-Shrimping from a Cart.

* We hoped to have had also an appendix on the fishing implements used in the district, written by our friend, Mr. Robert Lamb Ascroft, of Lytham, and illustrated by photographs taken by Mr. Andrew Scott ; but unfortunately, Mr. Ascroft's recent illness has, interrupted that and other good work in Natural History and Sea-Fisheries upon which he was engaged. We are indebted to Mr. Scott for most of the photographs from which our illustrations are taken. 


\section{APPENDIX I.}

\section{Draft Bye-laws for the Lancashire and Western Sea Fisheries District.}

At a Meeting of the Joint-Committee, held at Chester on Thursday, 25th April, 1901, the following bye-laws were adopted, and have now been submitted to the Board of Trade for confirmation:-

1.- The following bye-laws shall apply to the whole area of the Lancashire and Western Sea Fisheries District, unless otherwise specified, and except in the cases to which the provisions of the I 3 th Section of "The Sea Fisheries Regulation Act, 1888," apply. Provided that nothing in these bye-laws shall apply to any person fishing for sea fish for scientific purposes, or for stocking or breeding purposes, or removing mussels during the close season for use as bait under the written authority in that behalf of the Local Fisheries Committee, signed by their clerk or clerks, and in accordance with the conditions set out in that authority.

2.- -No artifice or device shall be used so as practically to diminish the size of the mesh of any net.

3.- No person shall use in fishing for sea fish any net with any trap or pocket, provided that this bye-law shall not apply to any person using a fish trawl net the mesh of which is in accordance with bye-law 4 .

4. - No person shall use in fishing for sea fish, other than shrimps, prawns, mackerel, herring, sparling, or garfish, any net having a mesh through which a square gauge of one and three-quarter inches, measured across each side of the square, or seven inches measured round the four sides, will not pass without pressure when the net is wet, provided that between the Ist day of June and the $1_{5}$ th day of November following, both inclusive, it shall be lawful to use a trawl net having a mesh through which a square gauge of one and a half inches, measured across each side of the square, or six inches measured round the four sides, will pass without pressure when the net is wet, on the seaward side of lines drawn between the following limits :-

(a) A line drawn straight from the south-west extremity of Haverigg Point, in Cumberland, to the north-ivestern extremity of Walney Island ;

(b) A line drawn straight from Walney lighthouse to the Wyre lighthouse ;

(c) A line drawn straight from the "Star Inn," South Shore, Blackpool, to the inner north-west sea mark on Formby Point ;

(d) A line drawn straight from the lifeboat-house at Formby to the Crosby lightship, and thence straight to Leasowe lighthouse, in the County of Chester.

5. - No person shall use, in fishing for sea fish other than shrimps or prawns, any trawl net except in accordance with the following regulations :-

(a) When the length of beam does not exceed eighteen feet between the trawl heads, or irons, the circumference of the net shall be not less than fifty meshes. 
(b) When the length of beam, measured as aforesaid, exceeds eighteen feet but does not exceed twenty-five feet, the circumference of the net shall not be less than sixty meshes.

(c) When the length of beam, measured as aforesaid, exceeds twenty-five feet, the circumference of the net shall be not less than eighty meshes.

6. - No person shall use in fishing for mackerel, herring, sparling, or garfish, any seine, draft, drift, set, or stake net having a mesh through which a square gauge of one inch, measured across each side of the square, or four inches measured round the four sides, will not pass without pressure when the net is wet.

7.--No person shall use in fishing for sea fish any drift net having a depth of more than 200 meshes.

8.- No person shall use in fishing for sparling any net or instrument between the first day of April and the thirty-first day of October following, both inclusive.

9. - No person shall use, in fishing for shrimps or prawns, any net having a mesh through which a square gauge of three-eighths of an inch, measured across each side of the square, or one and a half inches measured round the four sides, will not pass without pressure when the net is wet.

10.--No person shall use, in fishing for shrimps or prawns, any trawl net except in accordance with the following regulations :-

(a) When the length of beam between the trawl heads or irons does not exceed twenty feet, the circumference of the net shall be not less than one hundred and twenty meshes.

(b) When the length of beam, measured as aforesaid, exceeds twenty feet, the circumference of the net shall be not less than one hundred and forty meshes.

(c) The length of beam, measured as aforesaid, shall not exceed twenty-five feet.

11.-No person shall use, in fishing for shrimps or prawns, any shank or bow net having a less circumference than eighty meshes.

12.-No person shall use, in fishing for shrimps or prawns, any hand or hose net having a less circumference than seventy meshes.

13.--Any person who shall use any net authorised by these bye-laws for the capture of shrimps or prawns, shall forthwith return to the water with the least possible injury all other sea fish captured in such net.

14.--No person shall use in fishing for sea fish from any vessel propelled otherwise than by sails or oars, any method or instrument of fishing except hooks and lines.

15.-No person shall use in fishing for sea fish any stake net, except in accordance with the following regulations :-

(a) The site of the net shall be marked by poles, perches, or buoys, visible above the surface at high-water of any tide, and such poles, perches, or buoys shall be maintained so long as the stakes of the net continue in position. All stake nets shall be marked with the owner's name, affixed to the end stakes, so long as the stakes continue in position. 
(b) No portion of the net shall be nearer the centre of any stream or channel than the edge of such stream or channel at low-water of a tide, the high-water line of which stands sixteen feet above the level of the sill of the Old Dock at Liverpool.

(c) No portion of the net shall be nearer than one hundred and fifty yards to any portion of another stake net, not being a hose net.

(d) No mackerel baulk shall exceed 600 yards in length, no other stake net shall exceed 300 yards in length, and no stake net of the description known as a poke net shall exceed $r 50$ yards in length.

16. - No person shall use in fishing for mackerel, herring, garfish, sparling, shrimps, or prawns, any method or instrument of fishing, except at times and places at which and in the manner in which such method or instrument may be reasonably calculated to take such fish respectively.

17.-At the times and places at which, and in the manner in which it may be reasonably calculated to take eels or mullet only, an eel or mullet net may be used under the written authority in that behalf of the Local Fisheries Committee, signed by their clerks or clerk or superintendent, and in accordance with the conditions set out in that authority.

r. - No person shall use in fishing for sea fish any seine, draft, trawl, bow, hand, hose, shank, stake, or otter net in that portion of the district which lies between a line drawn true west from the building known as "Uncle Tom's Cabin," on the coast, near and north of the Borough of Blackpool, and a line drawn true west from the building known as the "Star Inn," on the coast, within the said borough.

19. - No person shall fish for cockles except-

(a) By hand, craam, rake, or spade, provided that between the first day of November and the last day of February following, both inclusive, it shall be lawful to use an instrument locally known as a Jumbo, not exceeding four feet six inches in length, fourteen inches in width, and one inch in thickness, provided that such instrument shall be constructed entirely of wood, and shall not be dragged across the cockle beds or artificially weighted.

(b) No person shall remove from a fishery any cockle which will pass through a gauge having a square opening of thirteen-sixteenths of an inch, measured across each side of the square.

20.- -No person shall fish for mussels, except-

By hand, or with a rake.

21. - No person shall remove from a fishery any mussels from the ist of April to the ${ }^{5} 5^{\text {th }}$ September following, both inclusive.

22.-No person shall use any kind of prawn or shrimp trawl net, dredge or shank net, on any mussel bed, or dig for worms on any mussel bed, except under the written authority in that behalf of the local Fisheries Committee, signed by their clerks or clerk or superintendent, and in accordance with the conditions set out in that authority.

23. - No person shall remove from a fishery any mussel less than two inches in length.

24. - No person shall remove from a fishery any oyster which will pass through a circular ring of two and a half inches in internal diameter. 
crab.

25. - No person shall remove from a fishery any berried lobster or any berried edible

26. - No person shall remove from a fishery-

(a) Any lobster measuring less than nine inches from the tip of the beak to the end of the tail when spread as far as possible flat.

(b) Any edible crab measuring less than five inches across the broadest part of the back.

27.-Any person who takes any shell fish, the removal of which from a fishery is prohibited by any of these bye-laws, or the possession of which is prohibited by any Act of Parliament, shall forthwith re-deposit the same as nearly as possible in the place from which they were taken, or, under the written authority of the Superintendent, on other suitable ground, and in re-depositing cockles in accordance with this bye-law, shall spread them thinly and evenly over the beds.

28.--No person shall use any method or instrument of fishing for sea fish other than the following :-

(a) A method or instrument permitted by these bye-laws.

(b) Hooks and lines.

(c) A pot, or basket, for taking eels, prawns, lobsters, crabs, or whelks.

(d) A hedge baulk in use previous to the 9 th of August, 1893 , the catching parts whereof consist wholly of net having a mesh in conformity with bye-law 4 .

29.--The deposit or discharge of any solid or liquid substance detrimental to sea fish or sea fishing is hereby prohibited, provided that this bye-law shall not apply ( 1 ) to the deposit by the Mersey Docks and Harbour Board within the area coloured brown on the Chart marked S. ${ }^{1568-1895}$, in the possession of the Board of Trade, of refuse or material dredged or excavated in the course of the execution under statutory power of any work by the said Docks and Harbour Board within the Port of Liverpool, or (2) to the deposit by any person, with the consent in writing of the Committee, given under the hand of their clerk or clerks, and confirmed by the Board of Trade, of any such solid or liquid substance on an area shown on a Chart referred to in the consent and in accordance with the conditions laid down in that consent.

30.--Any person who shall commit a breach of any of the foregoing bye-laws shall be liable to a penalty not exceeding for any one offence the sum of Twenty Pounds, and in the case of a continuing offence the additional sum of Ten Pounds for every day during which the offence continues, and in any case to forfeiture of any fishing instrument used or sea fish taken in contravention of or found in possession of a person contravening such bye-law.

31.-All bye-laws heretofore in force in the Lancashire and Western Sea Fisheries District are hereby repealed, provided that nothing in such repeal shall affect any penalty, forfeiture, or punishment incurred in respect of any offence committed against any bye-law so repealed. 


\section{APPENDIX II.}

\section{TABLES.}

Shorving Results of some Hauls rvith Experimental Fish Travol Nets having different sized meshes; also Result of some Experimental Hauls on Blackpool Closed Gronnds, Heysham Lake, and elsewhere: destruction to Undersized Sea Fish caused by Shrimp Nets, and other matters.

\section{Trials with 6 and 7 -inch meshes in Trawl Nets, showing the result with regard to the takes of Flukes.}

(I.) Six-inch mesh took 205 flukes under $\frac{1}{4} \mathrm{lb}$. Seven-inch mesh took 82 flukes under $\frac{1}{4} \mathrm{lb}$.

One drag of $\mathrm{I} \frac{1}{2}$ hours' duration.

Two boats used in the trial, nets down same time, beam same length.

(2.) Six-inch mesh took $66_{5}$ flukes, 332 under $\frac{1}{4} 1 \mathrm{~b}$.

Seven-inch mesh took 457 flukes, 148 under $\frac{1}{4} 1 \mathrm{~b}$.

In four drags.

Nets down same time. Two boats were used in three of the hauls.

(3.) In one drag of an hour's duration.- Mesh of over seven inches took ${ }_{1} 5$ score lbs. of fish, including 819 plaice, 57 of which were under $\frac{1}{4} 1 \mathrm{~b}$. Six-inch mesh took 248 plaice, 92 of which were under $\frac{1}{4} \mathrm{lb}$. - same time and place. There was no weed or debris in the nets to prevent the escape of fish. Our experience shows that the seven-inch mesh will take nearly all soles of $\frac{3}{4} \mathrm{lb}$., flukes of $\frac{1}{4} \mathrm{lb}$., and codling and haddlock of $\mathrm{ilb}$., and accidentally many under these weights.

(4.) The result of a number of hauls, a copy of which is appended, was as follows :- In nine hauls with the six-inch mesh, the total time the net was down being 14 hours 25 minutes, the takes amounted to 1,997 flukes, 932 being over $\frac{1}{4} \mathrm{lb}$. in weight each, and 1,065 under. In eight hauls with seven-inch mesh, the total time the net was down being 12 hours 27 minutes, the result was $\mathrm{r}, 557$ flukes, $\mathrm{r}, 269$ being over $\frac{1}{4} \mathrm{lb}$. each and 288 under.

Although the seven-inch mesh trawl was down 1 hour 58 minutes less time than the six-inch, it took 337 more fish over $\frac{1}{4} \mathrm{lb}$. in weight, and of undersized fish it took 777 less.

\section{With 6-inch Mesh-Nine Hauls.}

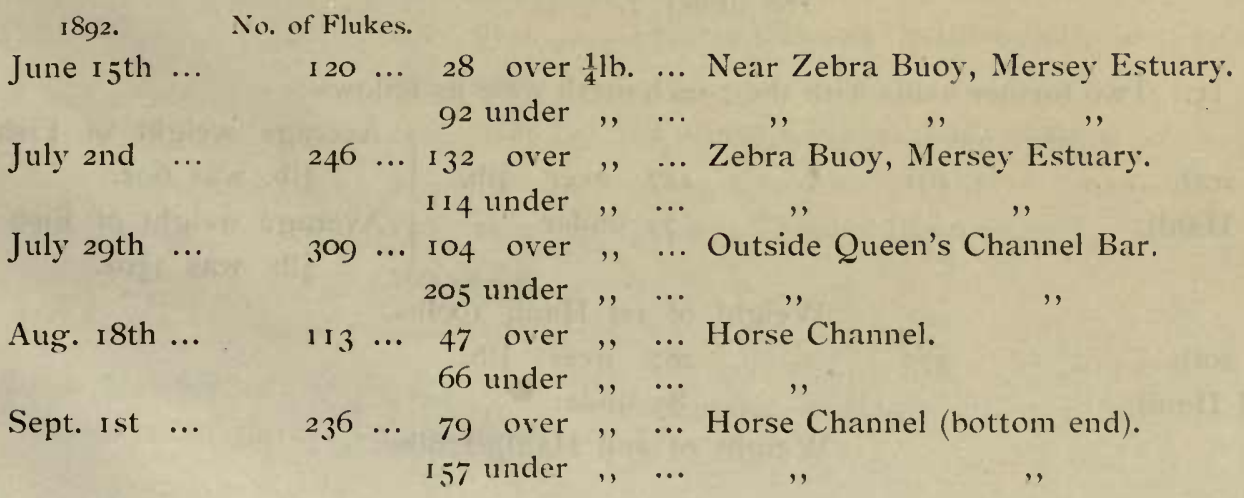


1892. No. of Flukes.

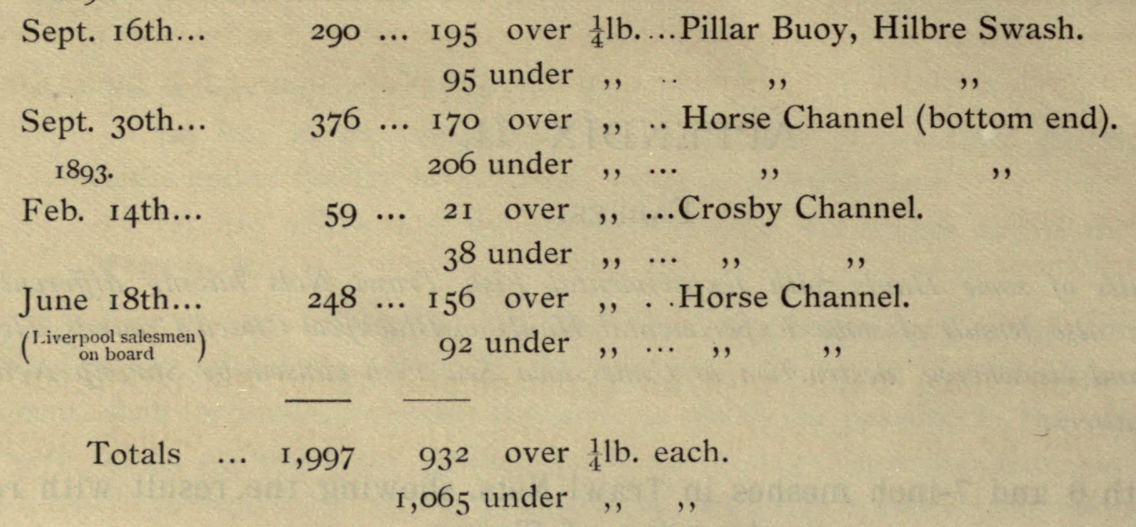

\section{With 7-inch Mesh-Eight Hauls.}

1892. No. of Flukes.

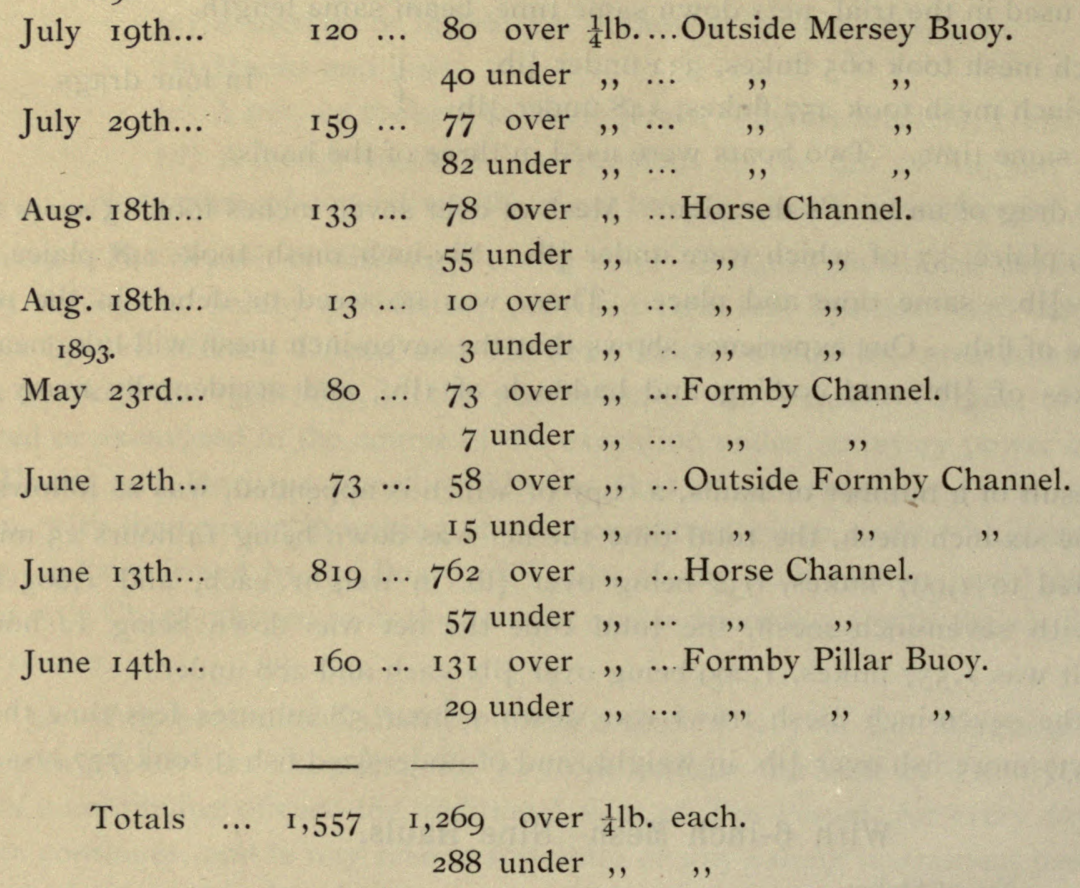

(5.) Two further hauls with the 7 -inch mesh were as follows :-

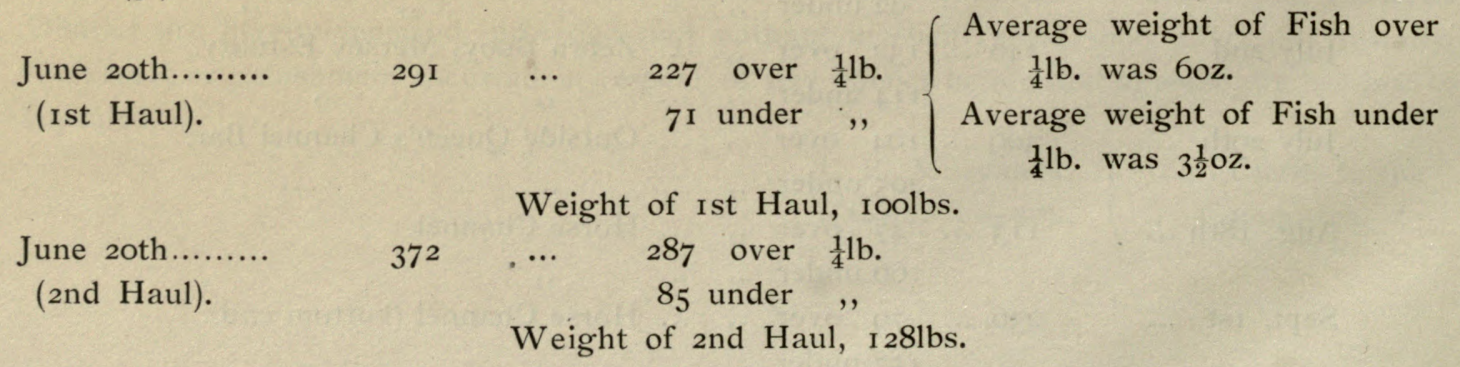


(6.) In the following four drags with a 6-inch mesh trawl, the number of flat fish under $\frac{1}{4}$ of a pound in weight was within one of being equal to the number of those over that weight, and in the 7 -inch mesh, with the same number of drags, the proportion of fish under $\frac{1}{4} 1 \mathrm{~b}$. was less than one half.

\begin{tabular}{|c|c|c|}
\hline & $\begin{array}{l}\text { Under } 1 / 4 \mathrm{lb} \text {. } \\
\qquad 33^{2} \text { and }\end{array}$ & $\begin{array}{c}\text { Over } 1 / 4 \mathrm{lb} . \\
333\end{array}$ \\
\hline 7 -inch & 148 & 309 \\
\hline
\end{tabular}

II. Result of some short hauls with an experimental Trawl Net of 6-inch mesh and 21 and 25 feet trawl beams, showing that Nets of 6-inch mesh are destructive to Plaice.

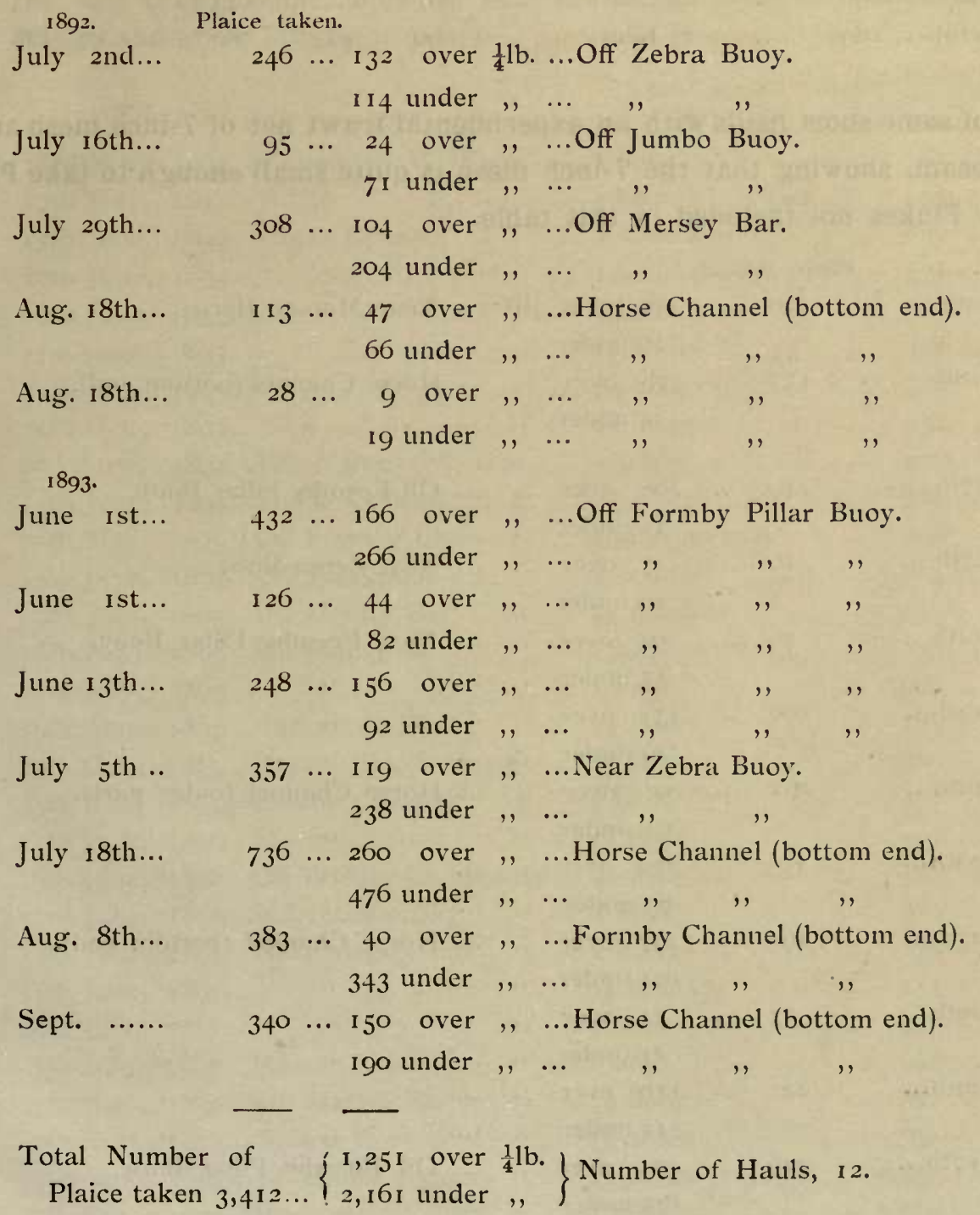


III. Result of a few hauls with an experimental fish trawl of 6-inch mesh and 25 feet trawl beam on Blackpool Closed Ground, showing that it is destructive to Plaice and other Flukes.

$\begin{array}{lllll}\text { Date. } & \begin{array}{l}\text { Duration } \\ \text { of haul. }\end{array} & \begin{array}{c}\text { Number of } \\ \text { Plaice and } \\ \text { other Flukes. }\end{array} & \begin{array}{c}\text { Number of Plaice } \\ \text { and other Flukes }\end{array} \text { under } 1 / 4 \text { lb. each. } & \begin{array}{c}\text { Total number } \\ \text { of }\end{array} \\ \text { Fish taken. }\end{array}$

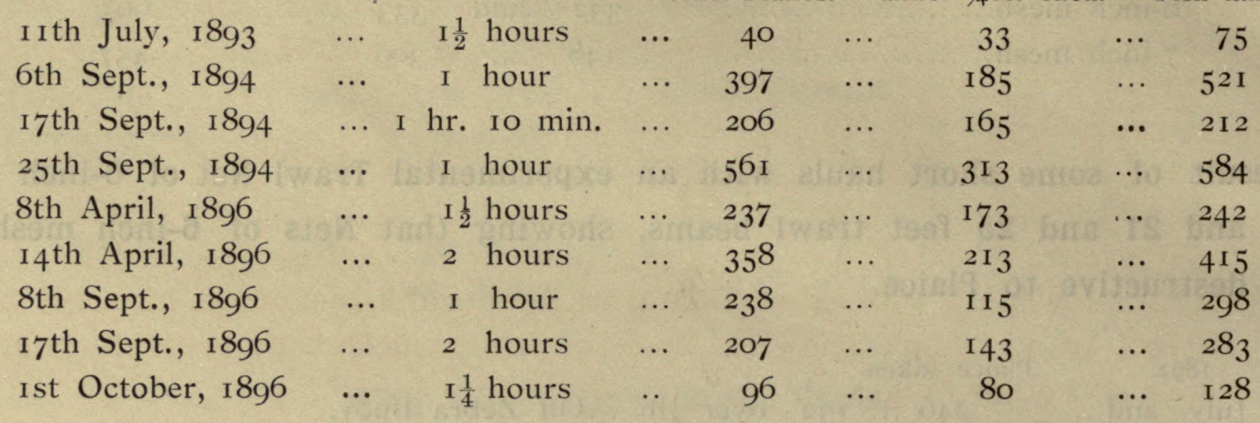

IV. Result of some short hauls with an experimental trawl net of 7-inch mesh and 25 feet beam, showing that the 7-inch mesh is quite small enough to take Plaice. Other Flukes not included in this table.

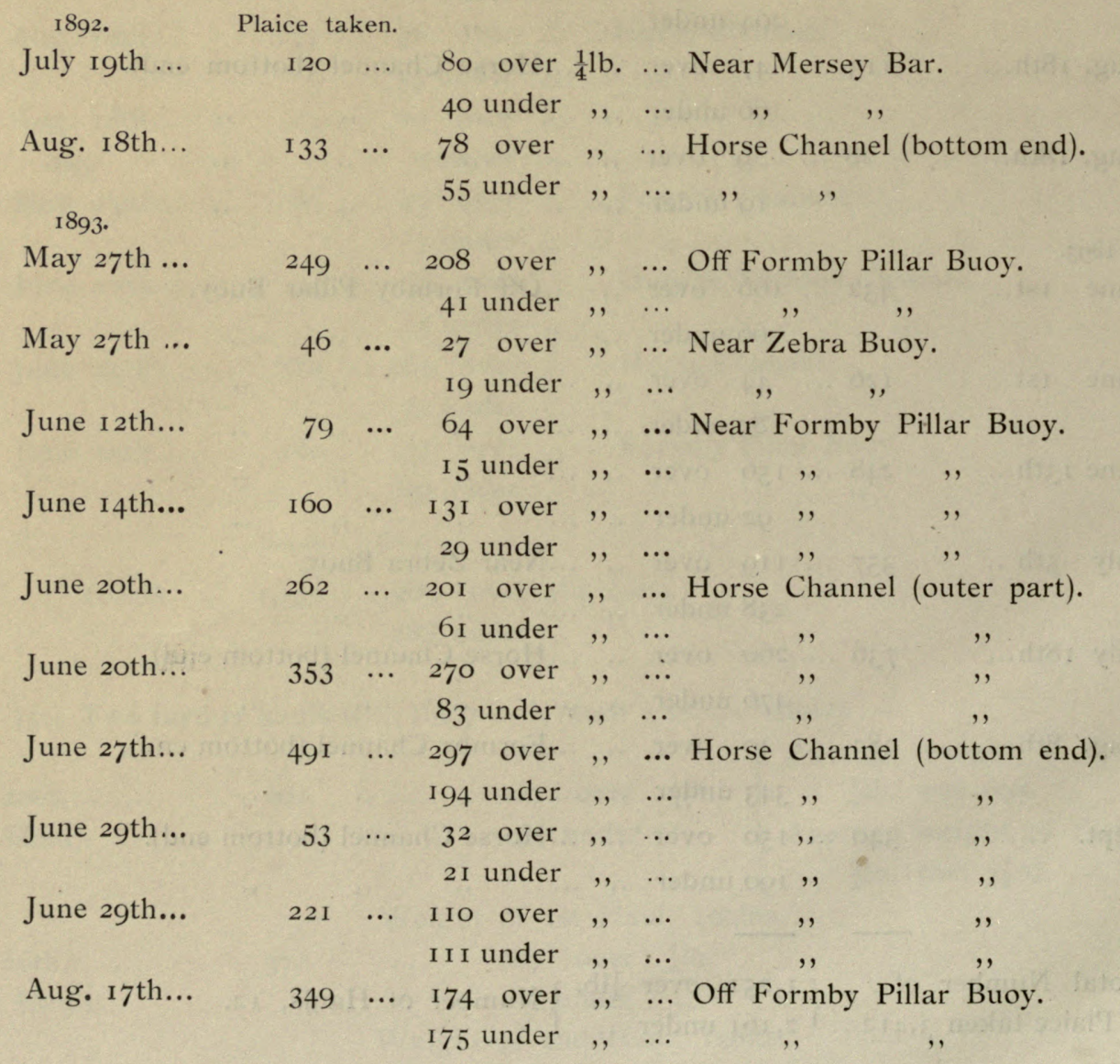




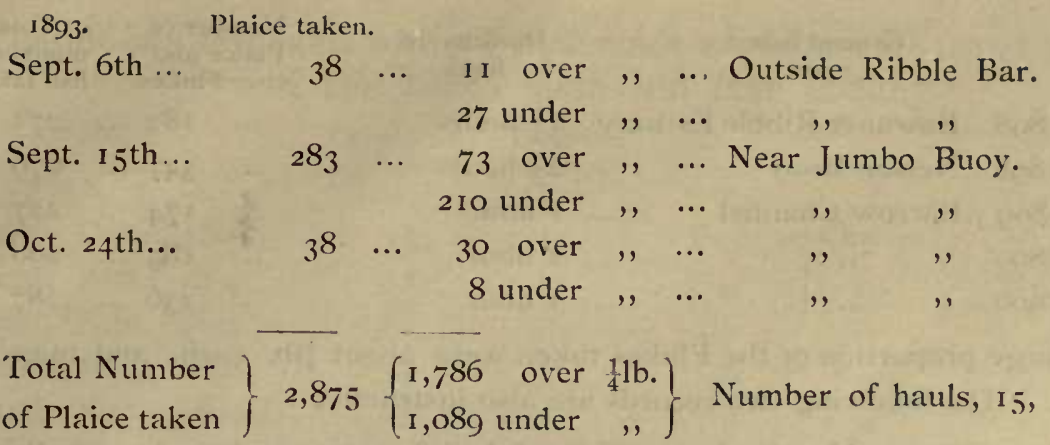

\section{Result of a few hauls with experimental trawl nets of 7 -inch mesh, and only 21 and 25 feet trawl beams, showing that the 7-inch mesh is quite small enough for Plaice and other Flukes.}

$\begin{array}{cc}\text { Date. } & \begin{array}{c}\text { Ground fished } \\ \text { upon. }\end{array} \\ \text { haulion of }\end{array}$

23rd May, I $893 \ldots$ Formby N.W. Buoy ... I hour

27th May, 1893... , , , , ... I hour

I $3^{\text {th }}$ June, 1893 ..Horse Channel $\ldots$ I hour $2 \mathrm{~min}$.

2oth June, r $893 \ldots$, ,

2oth June, I $893 \ldots \quad$, ,

2ist June, I $893 \ldots$, ,

27 th June, $1893 \ldots$

19th Oct., I $893 \ldots$, ,

and April, I $894 \ldots$ Pillar Buoy off Dee

I 5 th June, I $894 \ldots$ Horse Channel

28th May, $1895 \ldots$ Off Formby Channel

I $3^{\text {th }}$ June, I $895 \ldots$ Off Blackpool

9th July, I $895 \ldots$ Off Mersey Bar

I 8 th July, I895 ..Off Blackpool

2 Ist July, I $895 \ldots$

,'

19th Aug., I $895 \ldots$ Carnarvon Bay

29th Oct., I $895 \ldots$ Deposit Buoy, Mersey

25th Nov., 1895...Crosby Channel

I 7 th June, I 896 . Horse Channel

I 9 th June, $1896 \ldots$ Off Walney Lighthouse... 40 minutes

23rd June, 1896 ... Morecambe Bay

I 4 th June, $1897 \ldots$ Near Mersey Bar

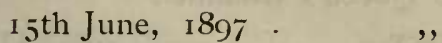

26th July, I $897 \ldots$

,"

7 th Aug., 1897 ... Horse Channel

7 th Sept., I 897 ... Off Mersey Bar

9th Sept., I $897 \ldots$ Nelson Buoy

I 3 th Sept., $1897 \ldots$ Off Ribble Estuary

7 th Oct., $1897 \ldots$ Blackpool
... I hour 20 min.

... I hour

... $I \frac{1}{2}$ hours

... $I_{4}^{\frac{1}{4}}$ hours

... $1 \frac{1}{2}$ hours

... I hour

... I $\frac{1}{2}$ hours

... I hour $20 \mathrm{~min}$.

... I hour

.. 35 minutes

... I hour ro min.

... I hour

... $1 \frac{1}{2}$ hours

.. $\mathrm{I} \frac{1}{2}$ hours

... $\frac{3}{4}$ hour

... $I^{\frac{1}{2}}$ hours

... $\mathrm{r}$ hour

... 2 hours

... $1 \frac{1}{2}$ hours

... I hour

... I hour

... $\mathrm{I}_{2}^{\frac{1}{2}}$ hours

... $1 \frac{1}{2}$ hours

... $I_{2}^{\frac{1}{2}}$ hours

... I hour

\begin{tabular}{|c|c|}
\hline $\begin{array}{l}\text { Number o } \\
\text { Plaice and } \\
\text { other Fluke }\end{array}$ & $\begin{array}{ll}\text { of } & \text { Total } \\
\text { d } & \text { number of } \\
\text { es. } & \text { fish taken. }\end{array}$ \\
\hline $\begin{array}{l}\ldots \\
\ldots 2\end{array}$ & $\ldots \quad 82$ \\
\hline .. 249 & 249 \\
\hline 857 & 858 \\
\hline 372 & $3^{89}$ \\
\hline 298 & 306 \\
\hline 237 & 557 \\
\hline $5^{24}$ & $53 \mathrm{I}$ \\
\hline $33^{8}$ & $34 \mathrm{I}$ \\
\hline 226 & 232 \\
\hline $5^{86}$ & 589 \\
\hline ... 398 & $\cdots 4^{1} 3$ \\
\hline$\cdots 3,084$ & $\cdots 3,095$ \\
\hline$\ldots \mathrm{I}, \mathrm{O}_{3} 8$ & $\ldots \mathrm{r}, 044$ \\
\hline$\ldots 1,036$ & $\ldots 1,042$ \\
\hline$\ldots \mathrm{I}, 086$ & $\ldots \quad 1,092$ \\
\hline$\ldots \quad I 29$ & $\ldots \quad$ I 54 \\
\hline$\ldots 2,069$ & $\ldots 2,070$ \\
\hline$\ldots \quad 203$ & $\cdots 3^{I_{4}}$ \\
\hline$\ldots \quad 203$ & $\ldots \quad 246$ \\
\hline $\begin{array}{ll}\ldots & 478\end{array}$ & $\ldots \quad 480$ \\
\hline $\begin{array}{ll}\cdots & 5^{15}\end{array}$ & $5^{15}$ \\
\hline $\begin{array}{ll}\ldots & \text { I } 70\end{array}$ & 295 \\
\hline $\begin{array}{ll}\ldots & \text { I } 35\end{array}$ & 224 \\
\hline $3^{23}$ & $39^{2}$ \\
\hline 647 & $\ldots \quad 667$ \\
\hline$\ldots 860$ & ... $86_{5}$ \\
\hline $\begin{array}{ll}\cdots & 53^{\mathrm{I}} .\end{array}$ & $\ldots 853$ \\
\hline$\ldots 2,34^{2}$ & .. 2,939 \\
\hline ... 2, 179 & $\ldots 2,233$ \\
\hline
\end{tabular}




$$
\begin{array}{cc}
\text { Date. } & \text { Ground fished } \\
\text { upon. } & \begin{array}{c}
\text { Duration of } \\
\text { haul. }
\end{array}
\end{array}
$$

9th Sept., I 898 ...Entrance Ribble Estuary $\mathrm{r}_{2}^{\frac{1}{2}}$ hours

$$
\text { I5th Sept., I } 898 \text {... Nelson Buoy ‥ } 2 \frac{1}{2} \text { hours }
$$$$
\text { 24th Nov, , } 1899 \text {. Barrow Channel }
$$$$
\text { 23rd Dec., 1899 . ", }
$$

I9th Feb., 1900...

$$
\begin{aligned}
& \ldots \text { I hour } \\
& \ldots \text { I hour }
\end{aligned}
$$$$
\begin{aligned}
& \text { Number of Total } \\
& \text { Plaice and number of }
\end{aligned}
$$$$
\text { other Flukes. fish taken. }
$$$$
\begin{array}{llllll}
\ldots & 182 & \ldots & 271
\end{array}
$$$$
\begin{array}{llll}
\ldots & 547 & \ldots & 679
\end{array}
$$$$
\text { … } 174 \quad \ldots \quad 227
$$$$
\begin{array}{lllllll}
\ldots & 185 & \ldots & 208
\end{array}
$$$$
\begin{array}{llll}
\ldots & 236 & \ldots & 287
\end{array}
$$

Note. - A very large proportion of the Flukes taken were about $\frac{1}{4} \mathrm{lb}$. each, and many were under that weight. The following two records are also instructive :-

November 2Ist, 1894.- Mr. Eccles, our head bailiff, went on board a small inshore Morecambe boat which was fishing just outside our boundary line, off the Mersey, with a full 7 -inch mesh, and saw taken with this net, in about 20 minutes, 2 cwt. of plaice.

June I $3^{\text {th, }}$ 1893. - At the bottom end of the Horse Channel, in a drag in which the net was down I hour and 2 minutes, with a trawl net of 7 -inch mesh and 25 -feet beam, $256 \mathrm{lbs}$. of fish were taken, principally plaice. Members of the Committee, and Liverpool fish salesmen

\begin{tabular}{|c|c|c|c|c|c|c|c|c|c|}
\hline & Date & & & $\begin{array}{l}\text { gth o } \\
\text { Bea } \\
\text { eet. }\end{array}$ & & $\begin{array}{c}\text { Duration } \\
\text { of Drag } \\
\text { Hours. }\end{array}$ & & Locality. & $\begin{array}{l}\text { Number } \\
\text { (or weight) } \\
\text { of Haddock. } \\
\text { Lbs. }\end{array}$ \\
\hline J 6 th & Nov., & 1893 & $\ldots$ & 21 & $\cdots$ & $1 \frac{1}{4}$ & .. & Horse Channel & . $\quad 33^{\circ}$ \\
\hline I 5 th & Jan., & I 894 & $\cdots$ & $2 I$ & & $\mathrm{I}_{4}^{\frac{1}{4}}$ & ... & , $\quad$, & 270 \\
\hline $3^{r d}$ & July, & I 896 & .. & 25 & .. & $1 \frac{1}{2}$ & ... & Formby Channel Entrance & 47 \\
\hline I 2 th & June, & I 897 & $\cdots$ & 25 & .. & 2 & $\ldots$ & Off Mersey Bar & 186 \\
\hline $14^{\text {th }}$ & June, & 1897 & .. & 25 & $\cdots$ & 2 & $\cdots$ & ," $\quad$, & II 4 \\
\hline $5^{\text {th }}$ & June, & I 897 & $\cdots$ & 25 & .. & $1 \frac{1}{2}$ & .. & ," & 69 \\
\hline 26th & July, & 1897 & ... & 25 & ... & I & .. & ," , , & 60 \\
\hline $9^{\text {th }}$ & Sept., & 1897 & $\cdots$ & 25 & ... & $\mathrm{I} \frac{1}{2}$ & $\cdots$ & Nelson Buoy & 42 \\
\hline I $3^{\text {th }}$ & Sept., & I 897 & $\cdots$ & 25 & ... & $1 \frac{1}{2}$ & ... & Off Ribble Estuary & 494 \\
\hline 2oth & Oct., & I 897 & .. & 25 & $\cdots$ & 2 & .. & Blackpool & 44 \\
\hline I 8 th & Nov., & г 897 & ... & 25 & & I & $\cdots$ & $\begin{array}{l}\text { Seaward Entrance to Rock } \\
\text { Channel }\end{array}$ & 202 \\
\hline 22nd & Mar., & 1898 & $\cdots$ & 25 & $\cdots$ & 4 & $\cdots$ & $\begin{array}{l}\text { I7 miles W.S.W. from } \\
\text { Black Combe }\end{array}$ & I 53 \\
\hline $9^{\text {th }}$ & Sept., & 1898 & $\cdots$ & 25 & & $I \frac{1}{2}$ & $\cdots$ & Off Ribble Estuary & 71 \\
\hline end & Nov., & 1898 & $\cdots$ & 25 & .. & $I \frac{1}{2}$ & ... & $\begin{array}{l}\text { Entrance Queen's Channel, } \\
\text { Mersey }\end{array}$ & 448 \\
\hline
\end{tabular}
and merchants, newspaper representatives, and others witnessed this haul.

VI. Results of a few hauls with experimental beam trawl net, 7-inch mesh, showing that the 7-inch mesh will take Haddock.

Note. - The 7 -inch mesh will take haddock of $\mathrm{Ilb}$, in weight, 
VII. Result of a few hauls with a 7-inch mesh experimental trawl net, showing that the 7-inch mesh will take Codling.

\begin{tabular}{|c|c|c|c|c|c|c|c|c|c|c|c|}
\hline \multicolumn{3}{|c|}{ Date. } & \multicolumn{3}{|c|}{$\begin{array}{l}\text { Length of } \\
\text { Trawl Beam. } \\
\text { Feet. }\end{array}$} & \multicolumn{2}{|c|}{$\begin{array}{l}\text { Duration } \\
\text { of Drag. } \\
\text { Hour. }\end{array}$} & \multirow[b]{2}{*}{ Barrow } & \multirow{2}{*}{$\begin{array}{l}\text { Locality. } \\
\text { Channel }\end{array}$} & \multirow{2}{*}{\multicolumn{2}{|c|}{$\begin{array}{c}\text { Number of } \\
\text { Codling. } \\
\text { Lbs. } \\
\text { 17 }\end{array}$}} \\
\hline $24^{\text {th }}$ & Oct., & 1896 & $\ldots$ & 23 & $\ldots$ & I & .. & & & & \\
\hline 24th & Feb., & 1897 & $\ldots$ & 23 & $\ldots$ & I & $\ldots$ & ", & ," & ... & 24 \\
\hline 26th & Feb., & 1897 & $\ldots$ & 23 & ... & I & ... & ," & ," & ... & 19 \\
\hline $22 \mathrm{nd}$ & Dec., & I 898 & $\ldots$ & 23 & $\ldots$ & I & ... & , & ," & $\ldots$ & 27 \\
\hline $24^{\text {th }}$ & Nor, & ז 899 & ... & 23 & $\cdots$ & I & $\ldots$ & ", & ," & $\ldots$ & 47 \\
\hline Ist & Dec., & 1899 & ... & 23 & $\cdots$ & I & $\ldots$ & ," & ," & $\ldots$ & 23 \\
\hline 22nd & Dec., & 1899 & $\ldots$ & 23 & $\ldots$ & I & $\cdots$ & ," & ," & $\cdots$ & 24 \\
\hline I $4^{\text {th }}$ & Feb., & 1900 & ... & 23 & $\ldots$ & I & $\ldots$ & ," & ," & $\ldots$ & 34 \\
\hline 19th & Feb., & 1900 & ... & 23 & ... & I & $\ldots$ & , & ," & $\cdots$ & 48 \\
\hline 2oth & Mar., & 1900 & $\ldots$ & 23 & $\ldots$ & I & $\ldots$ & ", & ," & $\ldots$ & I 8 \\
\hline
\end{tabular}

Note. - The 7 -inch mesh will take codling of $\mathrm{Ilb}$, weight.

VIII. Result of some hauls with a Shrimp Trawl on Blackpool Closed Ground, showing how injurious it would be to open this ground.

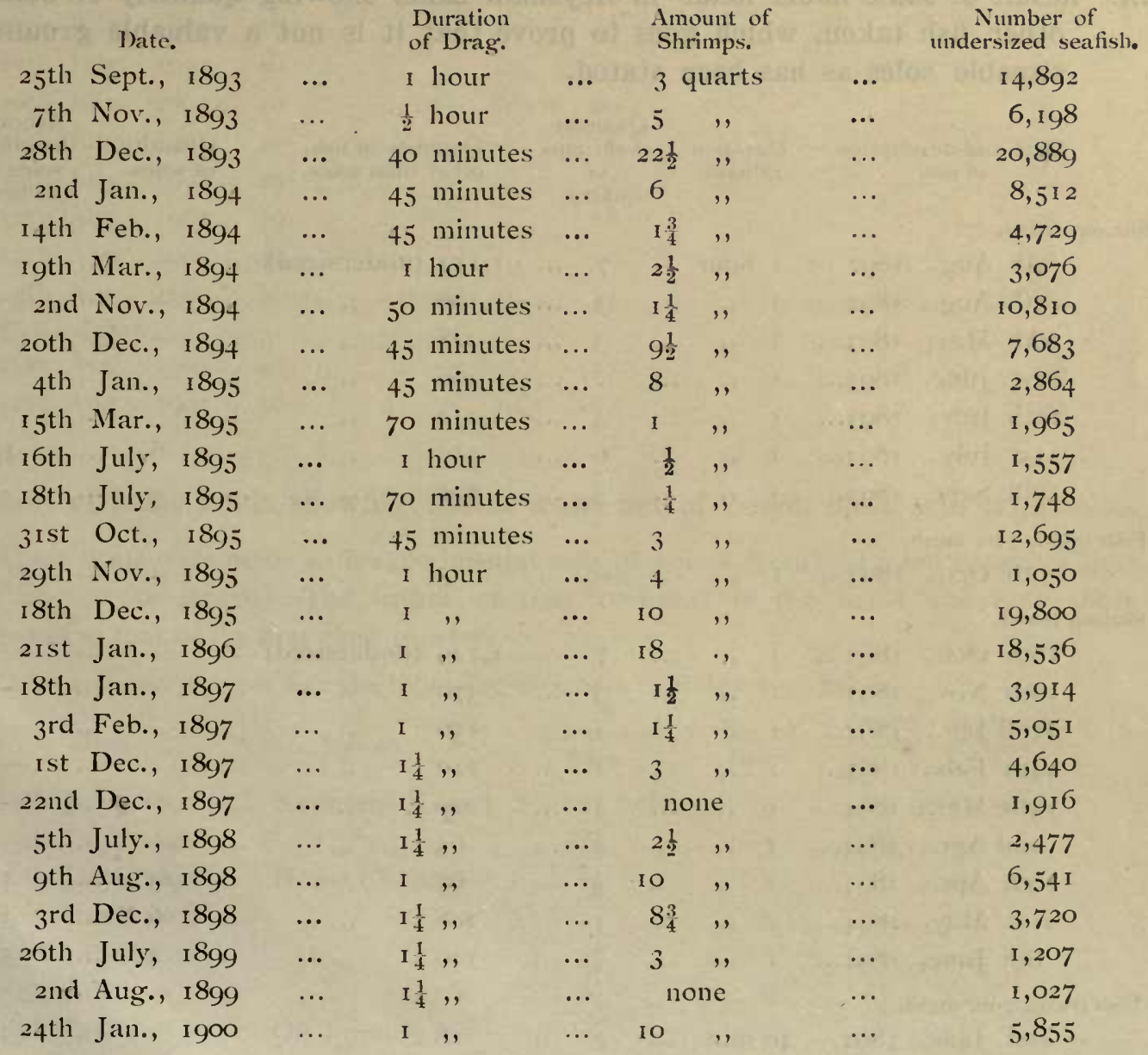




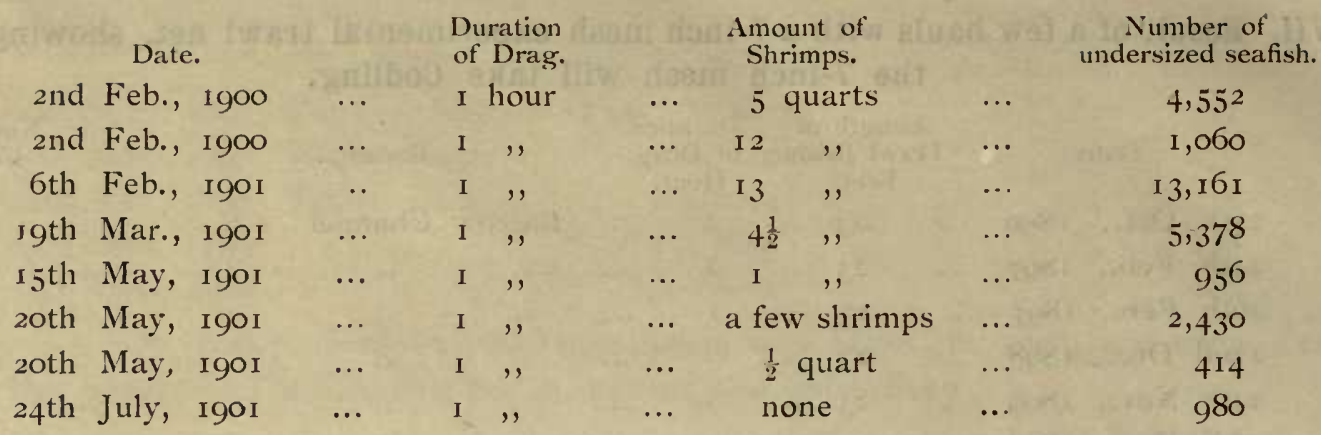

It should be remembered with regard to this ground that shrimpers would make several hauls pir day if it were not closed. The fish taken in the shrimp trawl chiefly comprise soles, plaice, dahs, codling, whiting, ray, and haddock.

The number of young soles on this ground keeps increasing.

On Blackpool Closed Ground line fishing is the main industry of the fishermen during the winter months.

IX. Result of some hauls made in Heysham Lake, showing quantity of Soles and other fish taken, which goes to prove that it is not a valuable ground for sizeable soles as has been stated.

\begin{tabular}{|c|c|c|c|c|}
\hline $\begin{array}{c}\text { Date and description } \\
\text { of net. }\end{array}$ & $\begin{array}{l}\text { Duration } \\
\text { of haul. }\end{array}$ & $\begin{array}{c}\text { Quantity } \\
\text { of shrimps } \\
\text { in } \\
\text { quaits. }\end{array}$ & $\begin{array}{l}\text { Quantity of fish, } \\
\text { other than soles. }\end{array}$ & $\begin{array}{l}\text { Quantity } \\
\text { of soles. }\end{array}$ \\
\hline
\end{tabular}

Shrimp trawl.

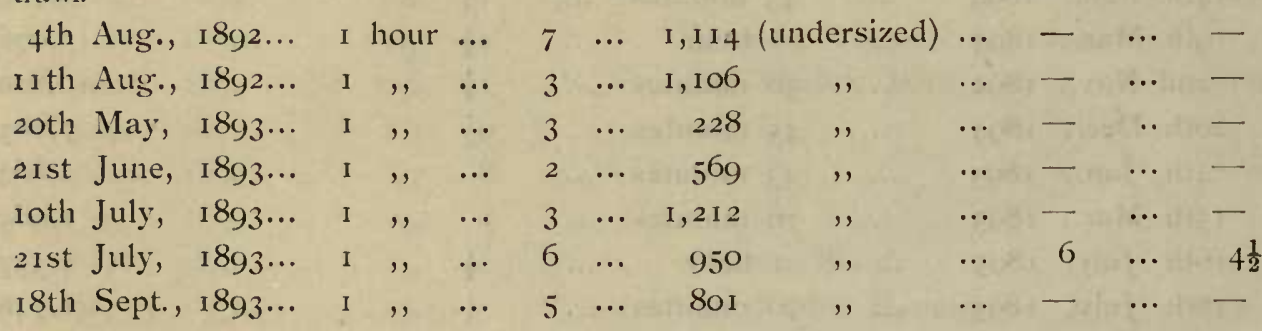

Fish trawl, 7-in. mesh.

$9^{\text {th }}$ Oct., $1893 \ldots$ I $\quad, \quad \ldots \quad-\ldots . \quad-\ldots$

Shrimp trawl.

\begin{tabular}{|c|c|c|c|c|c|c|c|c|c|c|}
\hline I6th Oct., & $1893 \ldots$ & $\frac{1}{2}$ & ", & $\ldots$ & & .. & I, I 29 & (undersized) & - & $\ldots \quad-$ \\
\hline I6th Nov., & I $893 \ldots$ & I & , & . & & $\cdots$ & 370 & , , & $\cdots$ & $\cdots$ \\
\hline 2nd Jan., & I $894 \ldots$ & I & , , & & & $\cdots$ & 156 & , & & \\
\hline 24th Feb., & I $894 \ldots$ & I & ," & & 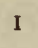 & ... & 210 & ", & $\cdots$ & $\cdots$ \\
\hline 1 $3^{\text {th }}$ Mar., & I $894 \ldots$ & I & , , & & I & ... & 220 & ," & $\cdots$ & \\
\hline d Apr., & I $894 \ldots$ & I & , & & 2 & $\cdots$ & $6_{3}$ & ," & $\ldots \quad-$ & $\cdots$ \\
\hline Ioth Apr., & $1894 \ldots$ & I & , & & & $\ldots$ & 97 & , & ... 23 & $\cdots$ \\
\hline t May, & I $894 \ldots$ & I & , & & & $\ldots$ & 208 & , & $\ldots$ & $\cdots$ \\
\hline 8th June, & I $894 \ldots$ & I & , , & & 4 & $\ldots$ & I 20 & ," & $\ldots$ & $\cdots$ \\
\hline
\end{tabular}

Fish trawl, 7-in. mesh.

2 Ist June, I $894 \ldots . .40$ min. ...

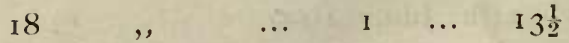




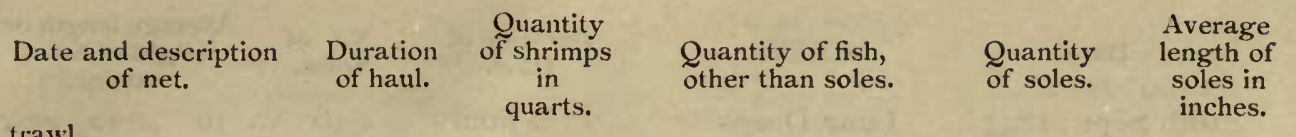
Shrimp trawl.

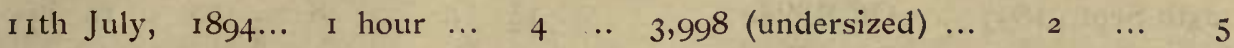

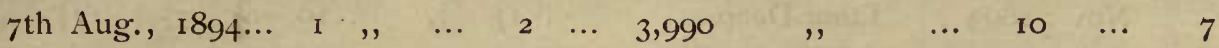

$\begin{array}{llllllllllllll}9 \text { th Nov., } 1894 \ldots & \text { I } & , & \ldots & 5 & \ldots & 3,997 & ,, & \ldots & 2 & \ldots & 6\end{array}$

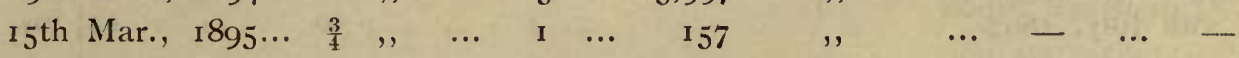

Fish trawl, 7 -in. mesh.

Shrimp trawl.

I $3^{\text {th }}$ June, I $895 \ldots$ I,,$\quad \ldots \quad-\ldots \quad$ I, I 83

$\begin{array}{llllllllrrrrr}\text { I } 7 \text { th June, } & \text { I } 895 \ldots & \frac{3}{4} & , & \ldots & \text { I } & \ldots & 25 & \text { (undersized) } & \ldots & - & \ldots & - \\ 23 \text { rd Mar., } & \text { I } 896 \ldots & \text { I } & , & \ldots & 1 & \ldots & \text { 1,260 } & , & \ldots & - & \ldots & -\end{array}$

Fish trawl, 6-in. mesh.

I4th Apr., I896... I $\quad,, \quad \ldots \quad-\ldots$

I 2 th July, $1897 \ldots$ 50 min. ... - ... 2 I

I6th July, I897... I hour ... - ... 8

3oth July, Igor... I, , ... $\quad$ - $\ldots . \quad 27$

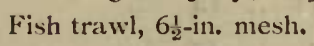

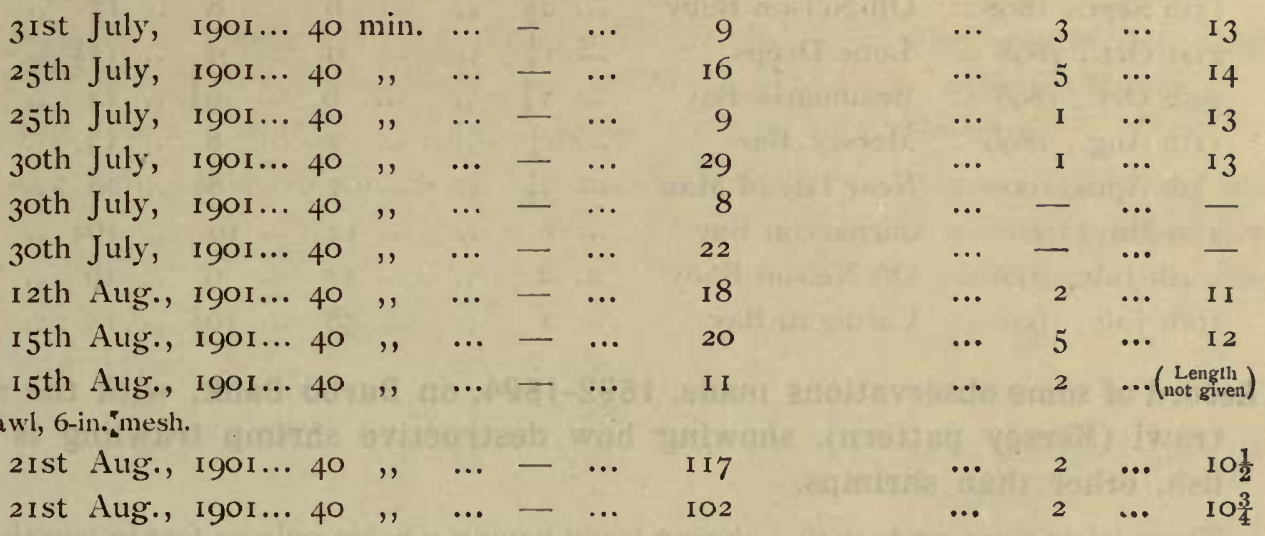

\section{Result of some hauls showing that a trawl net of 7-inch mesh will take Soles.}

These trials were made with experimental nets of 7 -inch mesh and trawl beams of only 21 and 25 feet in length. The length of time occupied in the hauls was only short as compared to that of the first class trawlers.

Over and above other fish the following numbers of Soles were taken :-

\begin{tabular}{|c|c|c|c|c|}
\hline Date. & Station. & $\begin{array}{l}\text { Duration of } \\
\text { haul. }\end{array}$ & $\begin{array}{l}\text { No. of } \\
\text { Soles. }\end{array}$ & $\begin{array}{l}\text { Average length or } \\
\text { weight of Soles } \\
\text { taken. }\end{array}$ \\
\hline
\end{tabular}

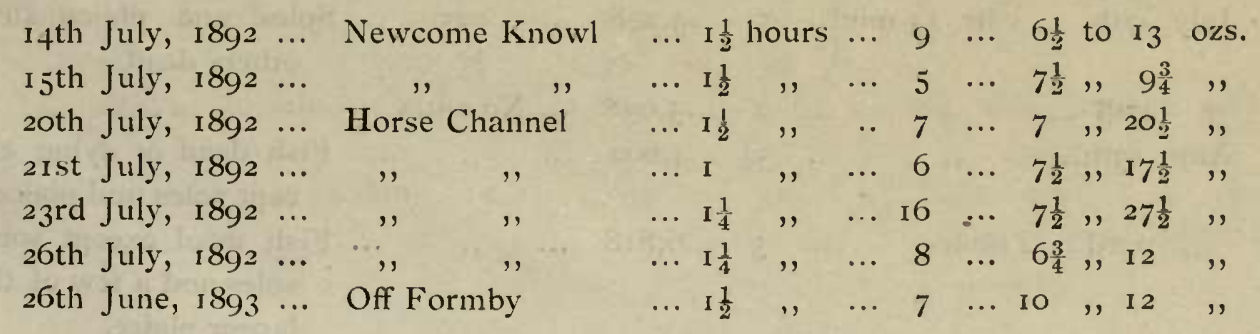




\begin{tabular}{|c|c|c|c|c|c|c|c|c|}
\hline Date. & Station. & $\begin{array}{c}\text { Duration } \\
\text { Haul. }\end{array}$ & & $\begin{array}{l}\text { No. of } \\
\text { Soles. }\end{array}$ & & $\begin{array}{l}\text { Avera } \\
\text { wei }\end{array}$ & $\begin{array}{l}\text { ght of Sol } \\
\text { taken. }\end{array}$ & $\begin{array}{l}\text { th or } \\
\text { oles }\end{array}$ \\
\hline 6th Sept., $1893 \ldots$ & Lune Deeps & ... 2 hou & urs & $\ldots \quad 16$ & & IO & , $12, \mathrm{C}$ & ozs. \\
\hline 5 th Sept., $1893 \ldots$ & Off Ribble & $\ldots \quad 1 \frac{1}{2}$ & , & $\ldots 8$ & ... & 10 & ,I $14 \mathrm{i}$ & ins. \\
\hline Nov., 1893 .... & Lune Deeps & $\ldots 2 \frac{1}{4}$ & ," & ... Io & .. & $99_{4}^{3}$ &,$\quad 12$. & , \\
\hline $9^{\text {th July, }}$ I $894 \ldots$ & Off Jumbo Buoy & $\ldots 1 \frac{1}{2}$ & ," & $\ldots 23$ & ... & 4 &, 18 & ozs. \\
\hline th July, $1894 \ldots$ & ," & $\ldots 2$ & ," & ... 10 & ... & II & , $15 \frac{1}{4} \mathrm{i}$ & ins. \\
\hline oth July, I894 ... & ," $\quad$, & $\ldots 2$ & ,, & $\ldots \quad 12$ & ... & II &, $14 \frac{1}{2}$ & , \\
\hline $4^{\text {th }}$ Aug., $1894 \ldots$ & Nelson Buoy & $\ldots 2$ & ," & $\ldots 13$ & .. & Io &,, $\mathrm{I}_{3}$ & , \\
\hline $4^{\text {th }}$ July, I $895 \cdots$ & Mersey Bar & $\ldots \quad 1 \frac{1}{4}$ & ," & $\ldots$ II & .. & I 2 &, 17 & , , \\
\hline 7 th June, I896 .. & Horse Channel & $\ldots \quad 1 \frac{1}{2}$ & , & $\ldots$ I 3 & $\cdots$ & & 12 & ins. \\
\hline 8 th Oct., i $896 \ldots$ & Lune Deeps & ... $\mathrm{I} \frac{1}{2}$ & , & $\ldots 15$ & $\cdots$ & I0 & , 16 & ," \\
\hline $4^{\text {th }}$ July, 1897 & Solway Firth & $\ldots \quad \mathrm{I} \frac{1}{2}$ & , & $\ldots 6$ & $\cdots$ & 10 &,, 12 & ", \\
\hline Ioth Aug., 1897 & Lune Deeps & $\ldots \quad I \frac{1}{2}$ & , & $\ldots{ }^{1} 5$ & $\ldots$ & I0 & ," 13 & ," \\
\hline $4^{\text {th Aug, }}$, 897 .. & Off St. Bees? Head & $\ldots \mathrm{I}$ & ;, & 8 & & $9 \frac{1}{2}$ &, 14 & , \\
\hline 4th Sept., $1897 \ldots$ & Lune Deeps & $\ldots \quad 1 \frac{1}{2}$ & , & ... 17 & $\cdots$ & $10 \frac{1}{2}$ &,,$\quad 16 \frac{1}{4}$ & , \\
\hline $7^{\text {th }}$ Jan., $1898 \ldots$ & Off Shore Grounds & ... 4 & ," & 5 & $\cdots$ & II &, 14 & ," \\
\hline $5^{\text {th }}$ Sept., 1898 & Off Nelson Buoy & $\ldots 2 \frac{1}{2}$ & , & 6 & & 8 &,$\quad 15$ & , \\
\hline Ist Oct., I $898 \ldots$ & Lune Deeps & ... I $\frac{1}{4}$ & ," & 9 & & 9 &, , $\quad \pm \frac{1}{2}$ & , \\
\hline 9 th Oct., I $898 \ldots$ & Beaumaris Bay & $\ldots \quad \mathrm{I} \frac{1}{4}$ & ," & 6 & & $9 \frac{1}{4}$ &, 14 & ," \\
\hline Ith Aug., i 899 ... & Mersey Bar & ... $1 \frac{1}{4}$ & ," & $\cdots$ & & 8 & , 13 & ," \\
\hline pril, r900 ... & Near Isle of Man & $\cdots 3 \frac{1}{2}$ & , , & $\ldots 7$ & & $8 \frac{1}{2}$ &,, 20 & , \\
\hline st May, tgor .. & Carnarvon Bay & $\ldots \mathrm{I}$ & , , & $\ldots \quad 12$ & ... & IO &,$\quad 16 !$ & ," \\
\hline $4^{\text {th July, } 1901 . . .}$ & Off Nelson Buoy & $\ldots 2$ & , & $\ldots$ I I & & 9 &,,$\quad 16$ & , \\
\hline th July, 190 I & Cardigan Bay & $\ldots 2$ & , & ‥ $5^{8}$ & $\cdots$ & $10 \frac{1}{2}$ &,, 13 & , \\
\hline
\end{tabular}

XI. Record of some observations made, 1892-1894, on Burbo Bank, with the shrimp trawl (Mersey pattern), showing how destructive shrimp trawling is to sea fish, öther than shrimps.

These trials were made with a shrimp trawl having a bean only 2 i feet in length (beams of 25 feet in length are allowed) from the Liverpool Fisheries sailing boat, which is of the size usually employed in shrimp trawling in our Southern Division. The shrimpers often make four or five drags in a day. The fish taken in the hauls enumerated below were chiefly soles, plaice, dabs, whiting, codling, and ray.

\begin{tabular}{|c|c|c|c|c|c|}
\hline Date. & $\begin{array}{l}\text { Time } \\
\text { net down. }\end{array}$ & $\begin{array}{c}\text { Quarts } \\
\text { of } \\
\text { Shrimps. }\end{array}$ & $\begin{array}{l}\text { Food } \\
\text { Fish } \\
\text { under } \\
4 \text { oz. }\end{array}$ & $\begin{array}{l}\text { Shrimp } \\
\text { Trawlers at } \\
\text { work on } \\
\text { this ground } \\
\text { at same time. }\end{array}$ & REMABKS \\
\hline
\end{tabular}
1892.

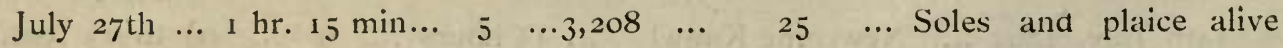
others dead.

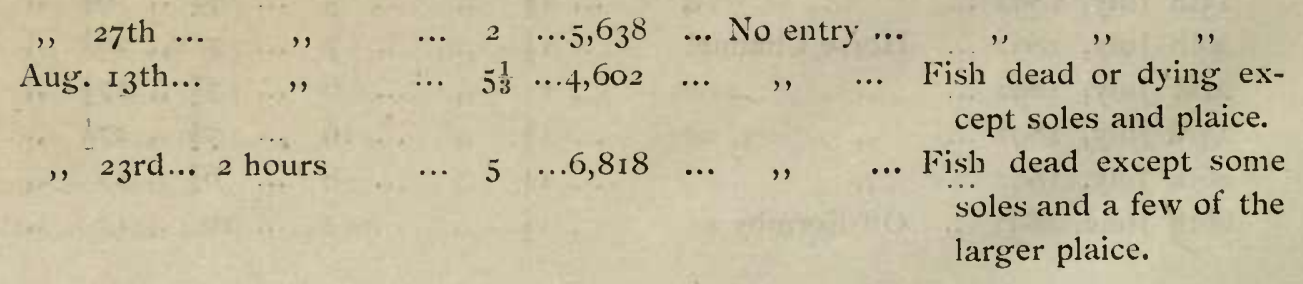




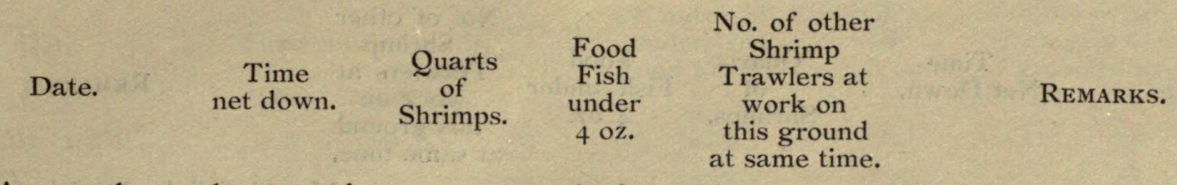

Aug. $5^{\text {th }} \ldots$ I hr. 30 min. .. $2 \quad \ldots 5,642 \quad \ldots$ No entry ... Fish dead or dying.

Captain Eccles, Head

Bailiff, Southern Division, states that on this date he boarded some boats shrimping in this district, as the men were getting the cod ends on board, and that there were in the nets not many short of ten thousand immature fish.

I893.

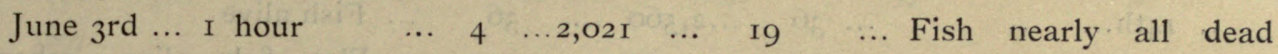
when net hauled.

Aug. I6th .. I hour $\quad \ldots$ I4 $\quad \ldots 2,689$.. $\quad$ I $\quad \ldots$ No entry.

Aug. 28th... I hr. Io min.... $29 \quad \ldots 3, \mathrm{I} 44 \quad \ldots \quad 4 \quad$.. A great number of fish were dead before they could be got out of the trawl.

$$
\begin{aligned}
& \text { Sept. I } 3 \text { th... , , } \\
& \text {,, I3th... ,, } \\
& \text {, I4th... ,, } \\
& \text {,, } 27 \text { th... I hr. } 30 \mathrm{~min} \ldots 3^{2} \quad \text { I } 1, \mathrm{O}_{32} \quad \ldots \quad \text { I2 }
\end{aligned}
$$

I 894
... Soles and plaice alive, others dying

Soles and plaice alive, other fish dead or dying.

All fish, except soles, dying or dead.

Aug. 2 Ist... I hr. $I_{5} \min \ldots \mathrm{I}_{5} \quad \ldots 5,672 \ldots$ 3I $\ldots$ Fish nearly all dead before they could be counted 


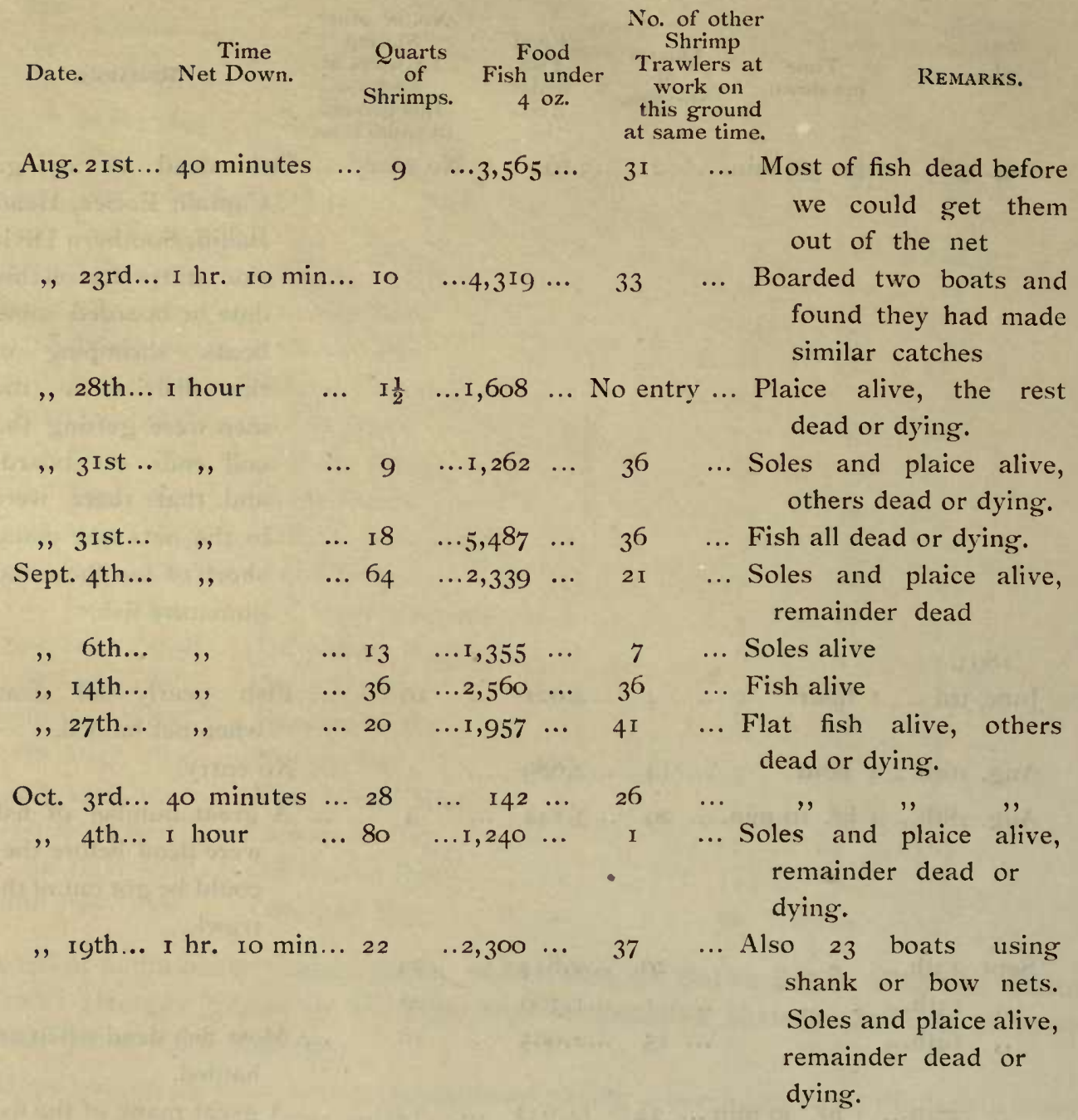

NotE.-Hauls have been made on this ground at other times of the year; but we have only mentioned here the hauls made in June, July, August, September, and October.

\section{XII.-Result of some experimental hauls made with the shrimp trawl on the Burbo Bank shrimping ground during the years 1895-1901.}

The fish taken were chiefly soles, plaice, dabs, whiting, haddock, codling, and ray. In considering the amount of undersized sea-fish taken in shrimp trawls, it should be remembered that each shrimp trawler makes several hauls during the day. It will be noticed that more undersized soles have been found during the years 1898 and 1899 than for some time past. This may possibly result from the fact that this ground was little fished upon by the shrimp trawlers in 1897 . Frequently, on days when the experimental hauls were made, other boats were boarded, and their takes were found to be similar. 


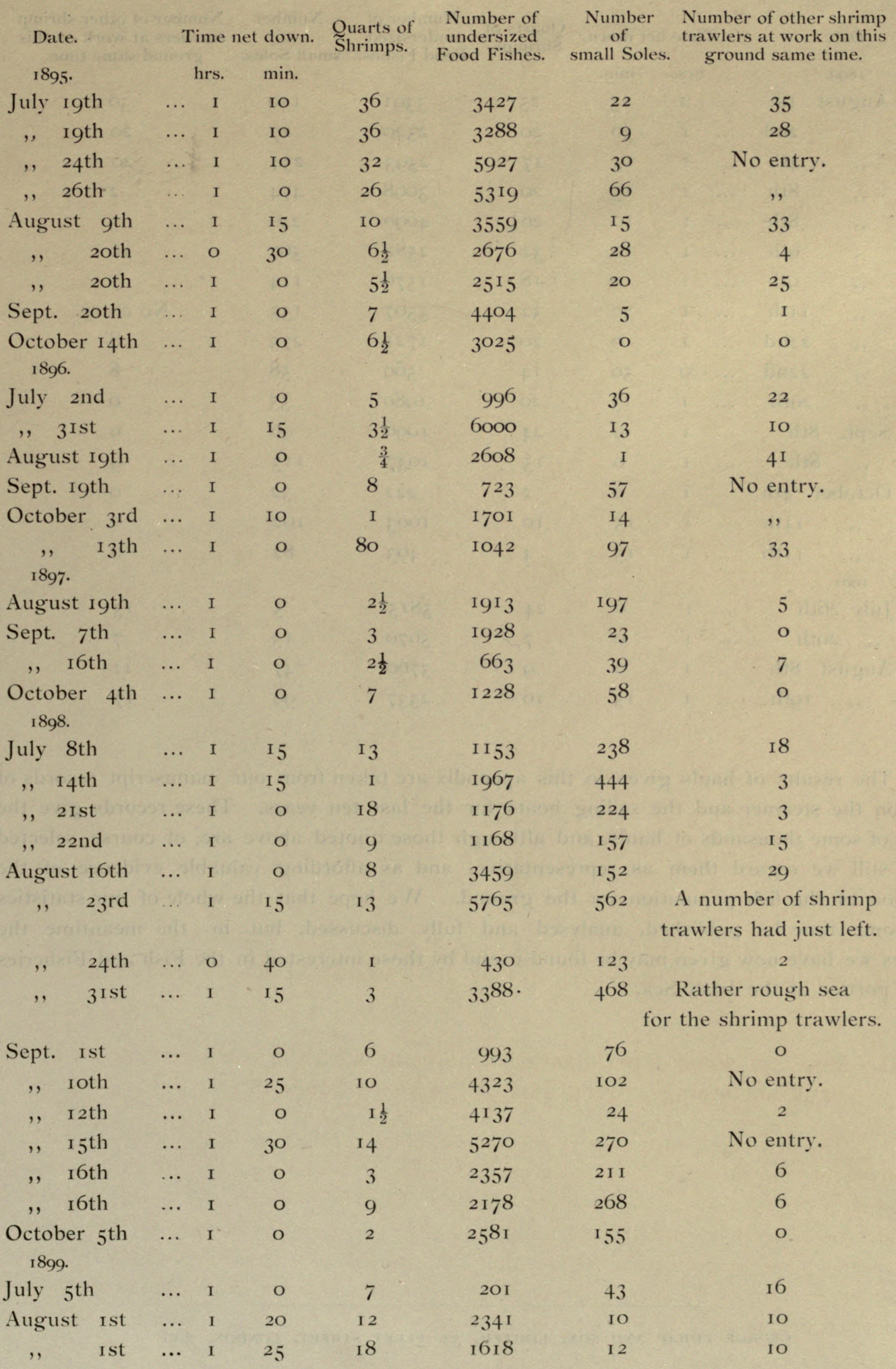




\begin{tabular}{|c|c|c|c|c|c|c|c|}
\hline $\begin{array}{l}\text { Date. } \\
\text { I } 899 .\end{array}$ & & $\begin{array}{l}\text { ime ne } \\
\text { hrs. }\end{array}$ & $\begin{array}{l}\text { down. } \\
\text { min. }\end{array}$ & $\begin{array}{l}\text { Quarts of } \\
\text { Shrimps. }\end{array}$ & $\begin{array}{c}\text { Number of } \\
\text { undersized } \\
\text { Food Fishes. }\end{array}$ & $\begin{array}{l}\text { Number } \\
\text { of } \\
\text { small Soles. }\end{array}$ & $\begin{array}{l}\text { Number of other shrimp } \\
\text { trawlers at work on this } \\
\text { ground same time. }\end{array}$ \\
\hline August ist & ... & I & ${ }^{1} 5$ & 25 & 3391 & 140 & 30 \\
\hline 2nd & $\cdots$ & I & 30 & 20 & 2520 & 27 & 20 \\
\hline $4^{\text {th }}$ & ‥ & I & I5 & 17 & 2593 & 234 & 20 \\
\hline 8 th & $\cdots$ & I & I 5 & 20 & 3098 & 474 & 2 \\
\hline 8 th & $\cdots$ & I & IO & $26 \frac{1}{4}$ & 4090 & 246 & 3 \\
\hline $9^{\text {th }}$ & ... & I & IO & $3^{2}$ & $25^{82}$ & $5^{67}$ & I6 \\
\hline $9^{\text {th }}$ & ... & I & o & 18 & I 576 & II 4 & 7 \\
\hline IIth & $\cdots$ & I & 30 & 32 & 3507 & I 55 & No entry. \\
\hline 22nd & $\cdots$ & I & o & 20 & 1721 & 275 & 8 \\
\hline $22 n d$ & ... & o & 50 & 14 & $5^{69}$ & $5^{8}$ & 8 \\
\hline ,, 29 th & ... & I & ${ }^{\prime} 5$ & 20 & 1980 & 55 & o \\
\hline Sept. 8 th & ... & I & 0 & 24 & $\log 6$ & 96 & 9 \\
\hline ,, 8th & $\cdots$ & I & o & I 5 & 1037 & II 3 & 9 \\
\hline October $4^{\text {th }}$ & $\ldots$ & I & o & 2 & 222 & $3^{2}$ & o \\
\hline ,, IIth & $\cdots$ & I & ${ }^{1} 5$ & IO & 1003 & 102 & o \\
\hline $\begin{array}{l}\text { IIIth } \\
\text { I9or. }\end{array}$ & $\because$. & I & ${ }^{1} 5$ & 4 & $46_{3}$ & 82 & o \\
\hline July 26 th & ... & I & o & 24 & $5^{8}$ I 5 & 5 & I3 \\
\hline,$\quad$ 29th & ... & I & o & 7 & $5^{670}$ & I 3 & 7 \\
\hline August 8th & -. & I & o & 9 & 3760 & 47 & II \\
\hline ,, Igth & ... & I & I5 & I6 & 2337 & 99 & 17 \\
\hline
\end{tabular}

The results of hauls given in this appendix are taken from our manuscript records of work on the steamer and the sailing boats for the last ten years. These records give the details of some thousands of hauls, and although those quoted above are, of course, selected hauls, still we regard them as representative, and as affording valuable evidence of the condition of the fish population on the ground. We hope that the whole of our statistics may some time be published, analysed and fully discussed, but in the meantime the samples we have now given may be found useful by those interested in the Fish and Fisheries of our portion of the Irish Sea. 


$$
3-i
$$



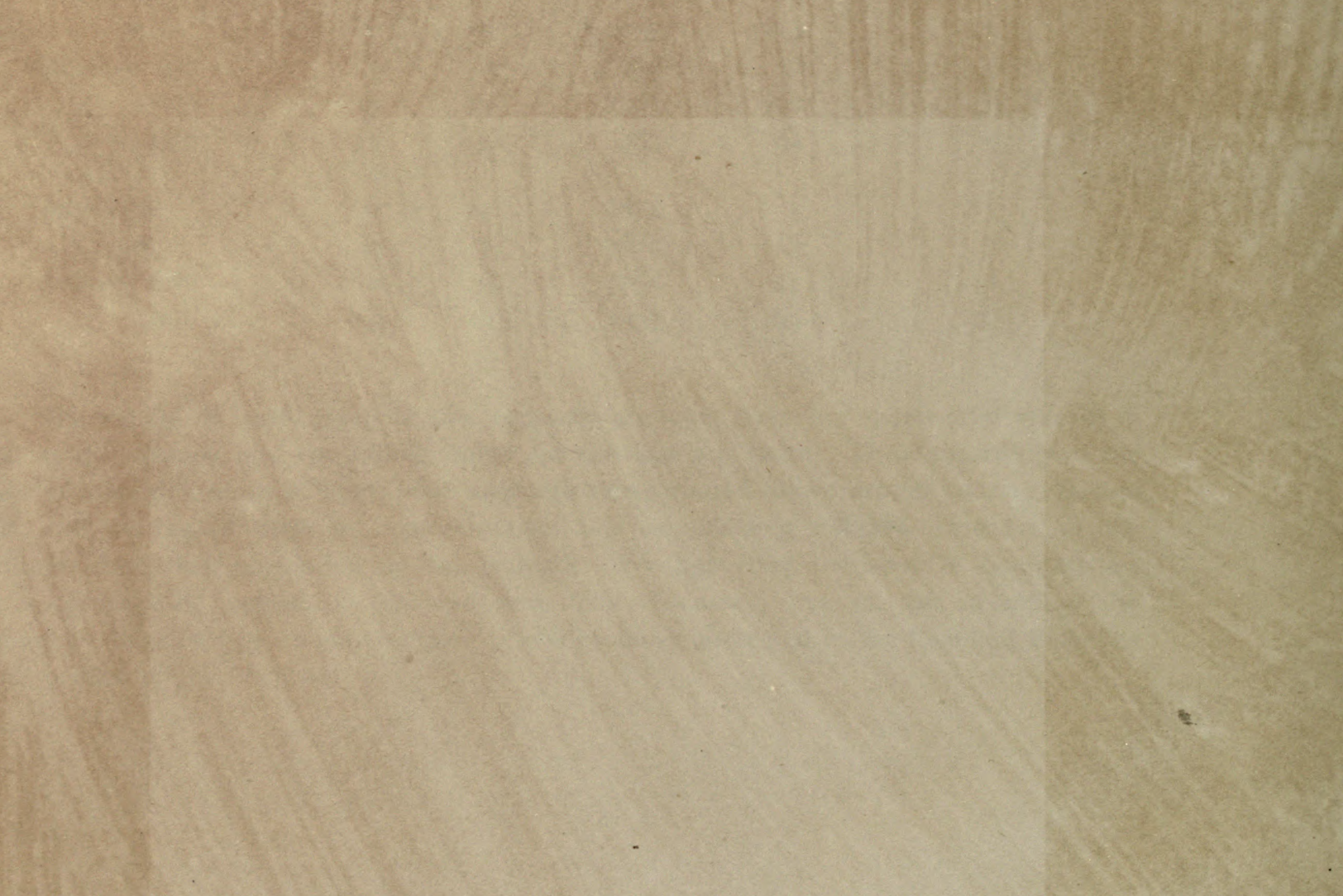

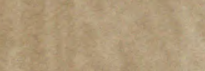

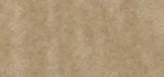
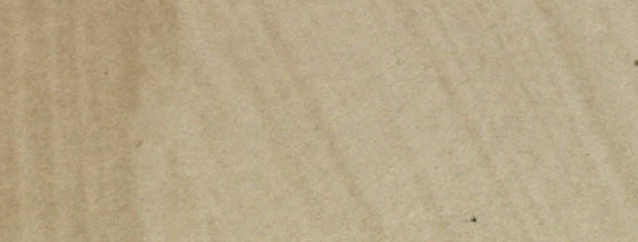

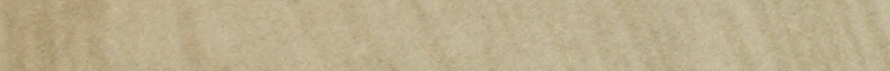

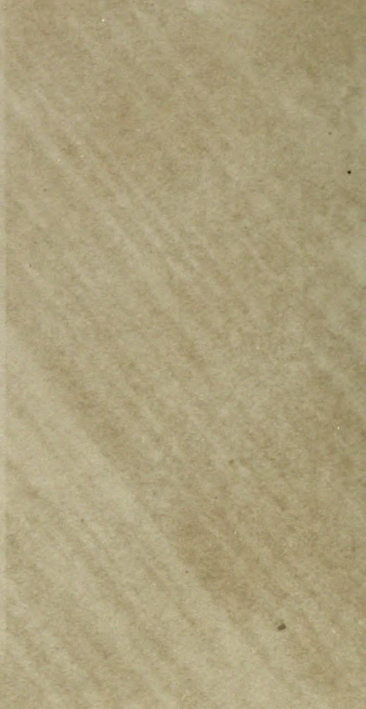




\section{UNIVERSITY OF CALIFORNIA LIBRARY}

BERKELEY

Return to desk from which borrowed.

This book is DUE on the last date stamped below.

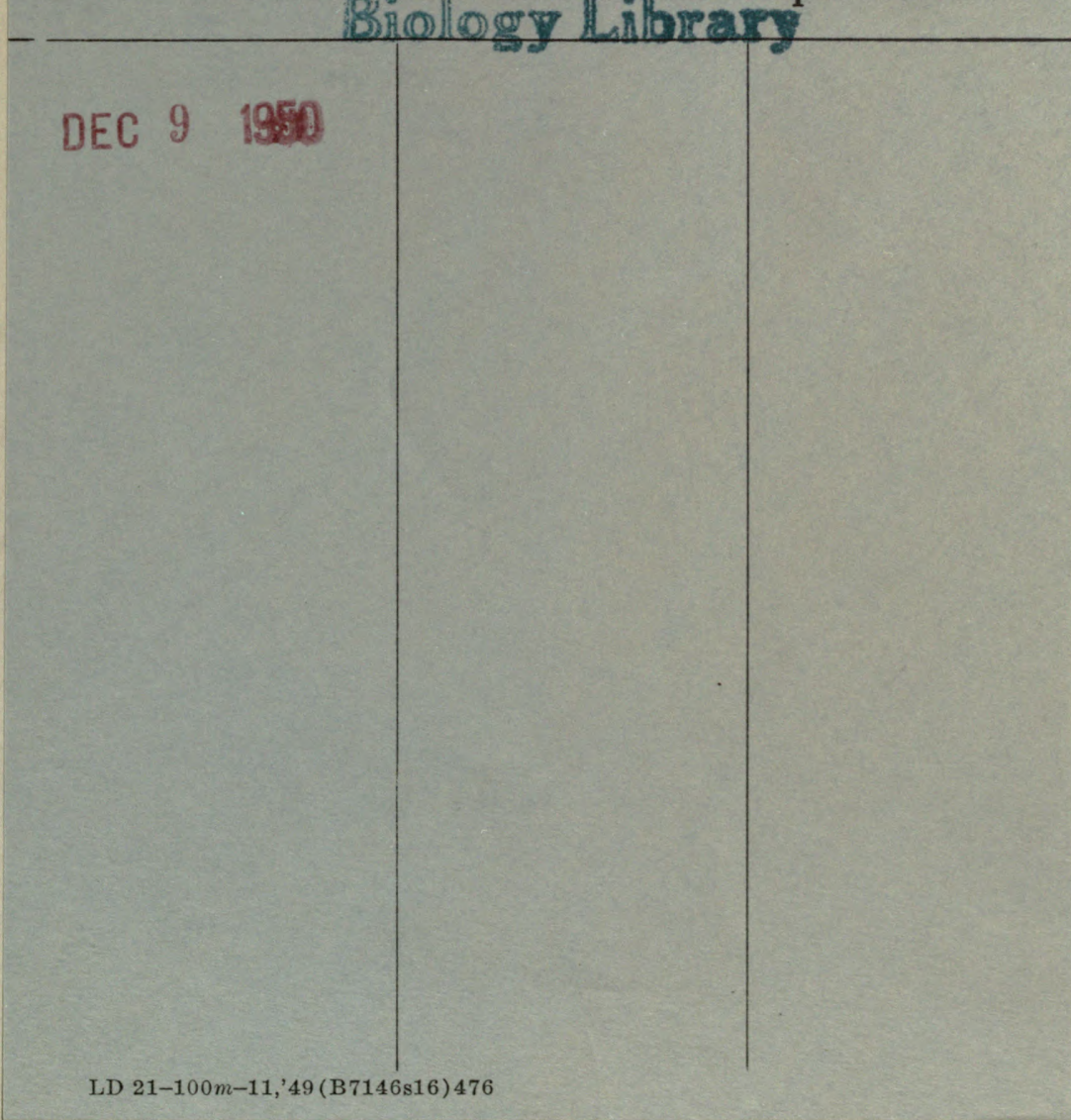


